\title{
United Arab Emirates: Selected Issues and Statistical Appendix
}

The Selected Issues and Statistical Appendix Paper on the United Arab Emirates was prepared by a staff team of the International Monetary Fund as background documentation for the periodic consultation with the member country. It is based on the information available at the time it was completed on April 6, 2011. The views expressed in this document are those of the staff team and do not necessarily reflect the views of the government of United Arab Emirates or the Executive Board of the IMF.

The policy of publication of staff reports and other documents by the IMF allows for the deletion of market-sensitive information.

Copies of this report are available to the public from

International Monetary Fund • Publication Services

$70019^{\text {th }}$ Street, N.W. • Washington, D.C. 20431

Telephone: (202) 623-7430 • Telefax: (202) 623-7201

E-mail: publications@imf.org Internet: http://www.imf.org

\section{International Monetary Fund Washington, D.C.}




\title{
INTERNATIONAL MONETARY FUND
}

\section{UNITED ARAB EMIRATES}

\section{Selected Issues and Statistical Appendix}

\author{
Prepared by Gabriel Sensenbrenner, Serhan Cevik, Vincenzo Guzzo, \\ and Arthur Ribeiro da Silva \\ Approved by the Middle East and Central Asia Department
}

April 6, 2011

Contents

Page

I. Risks Posed by Government-Related Entities in the United Arab Emirates...........................4

A. Introduction...............................................................................................

B. Which Types of Risks Emerged in the Context of Dubai's Debt Restructuring?.....6

C. What Are the Main Risks Posed by the GREs Going Forward?...............................8

D. Which GREs are Currently the Main Sources of Contingent Risk? ........................14

E. Policies to Manage GRE Risk ............................................................................18

II. Ensuring Financial Sector Stability in the United Arab Emirates......................................20

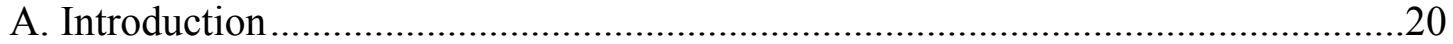

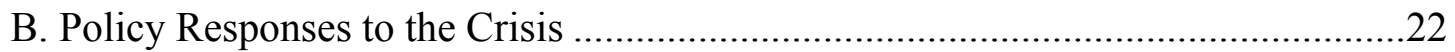

C. Current Conditions and Vulnerabilities..............................................................24

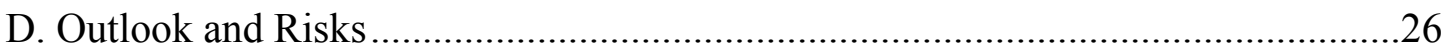

E. Policies for Financial Stability ............................................................................32

III. Fiscal Policy and Fiscal Coordination in the United Arab Emirates: Drawing Lessons

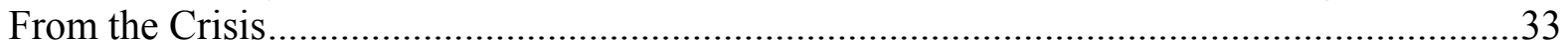

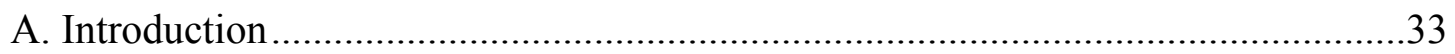

B. Fiscal Federalism in the U.A.E. ..........................................................................

C. Cyclicality of Fiscal Policy Before and After the Crisis ..........................................34

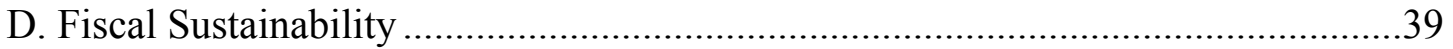

E. Policy Issues .............................................................................................

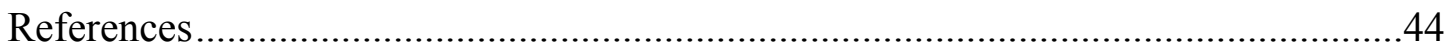

Tables

I.1. 2010 Selected Sovereign Issues....................................................................................

I.2. Dubai: Publicly-Held Debt in the Form of Bonds and Syndicated Loans.........................11

I.3. Abu Dhabi: Publicly-Held Debt in the Form of Bonds and Syndicated Loans..................13 


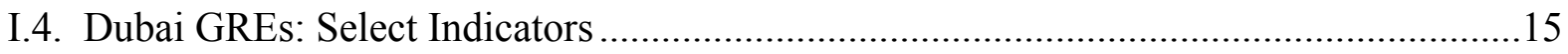

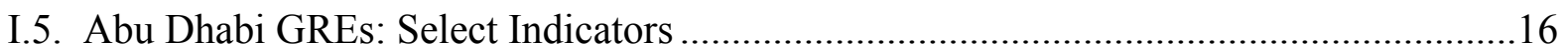

I.6. UAE Real Estate GRE vs. Regional Peers: Selected Indicators.......................................17

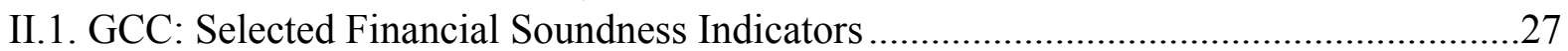

II.2. Disaggregated Financial Soundness Indicators, December $2010 \ldots \ldots \ldots \ldots \ldots \ldots \ldots \ldots \ldots \ldots \ldots \ldots \ldots . . .27$

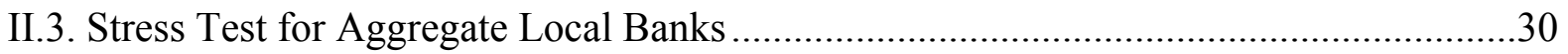

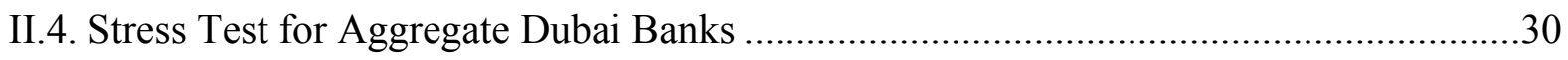

Figures

I.1. Dubai Inc. ....

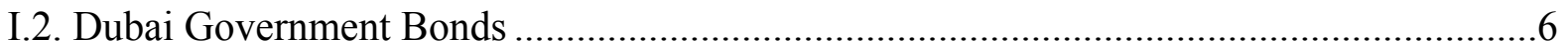

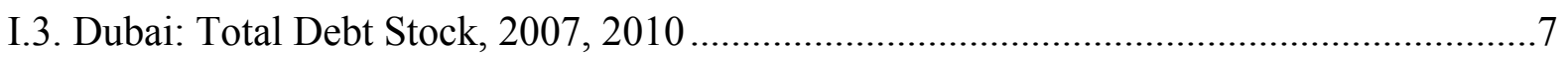

I.4. Total Gross Debt, 2010

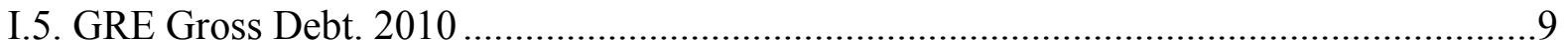

I.6. Total Gross Debt: Cross-Country Comparison, 2010 ....................................................10

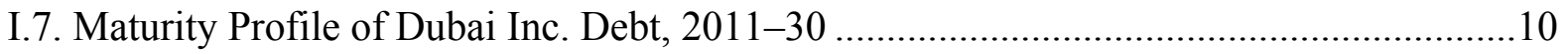

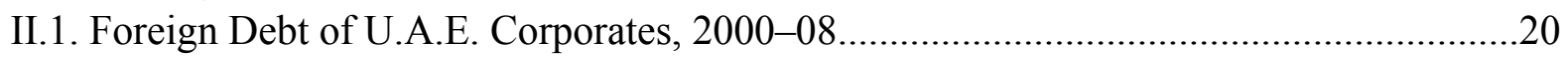

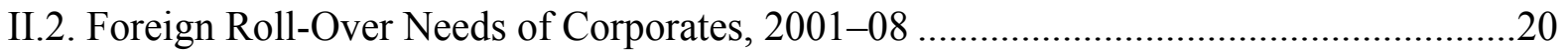

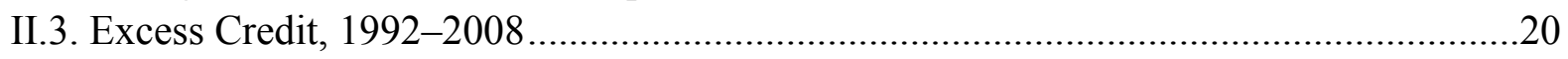

II.4. Credit Growth and Capital Adequacy Ratios in Selected Emerging Markets .................20

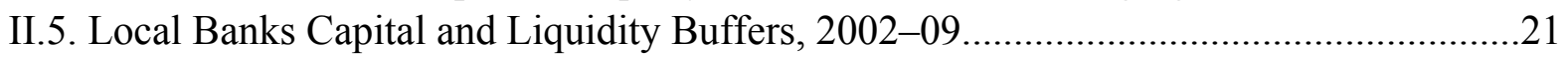

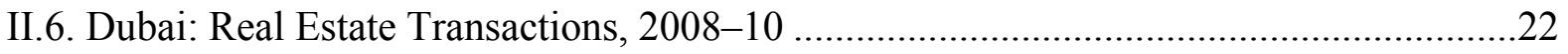

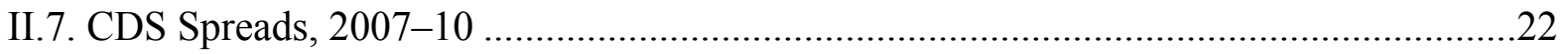

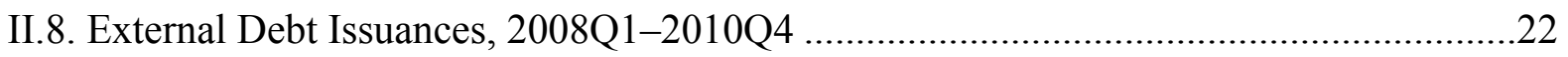

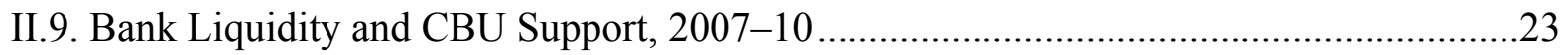

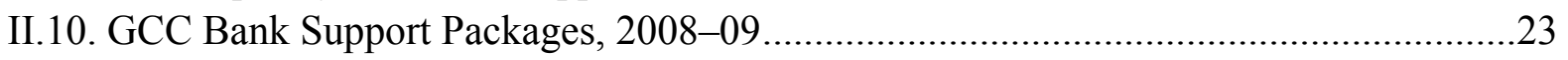

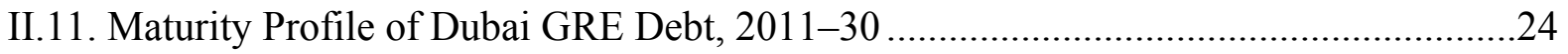

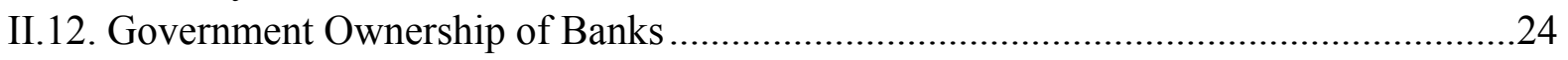

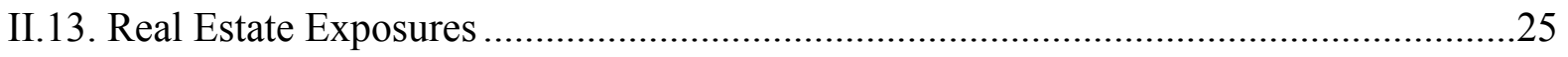

II.14. Share of Credit to Real Estate and Construction........................................................25

II.15. NPL Path in Selected Banking Markets with Acute Property Bubbles .........................29

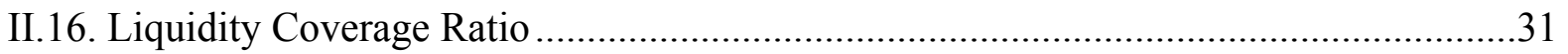

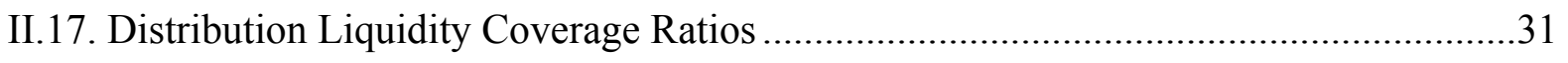

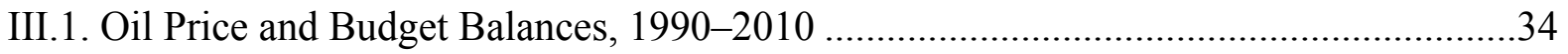

III.2. Output Gap, Inflation, and Expatriate Workers .............................................................. 35

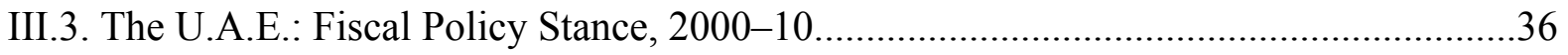

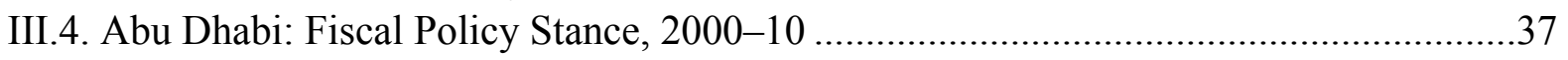

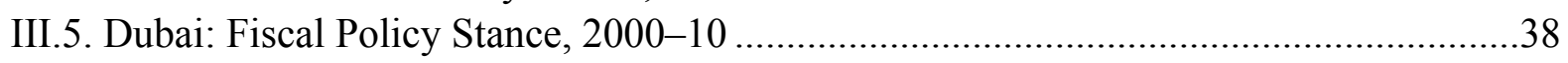

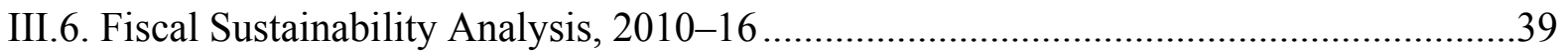

III.7. Dubai: Public Sector Debt Sustainability Analysis, 2002-16 ....................................41 
Boxes

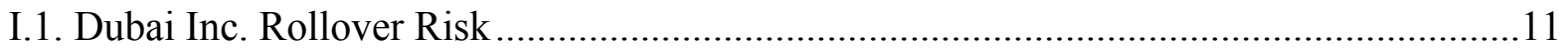

II.1. Central Bank Regulations on Loan Classification and Provisioning ..............................26

Appendix

III.1. Dubai: Public Sector Debt Sustainability Framework, 2007-16 .43

Statistical Appendix

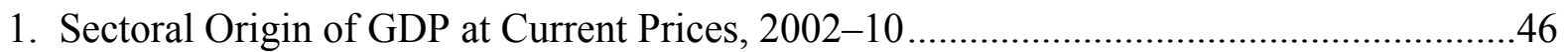

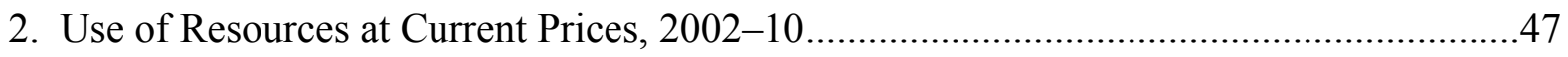

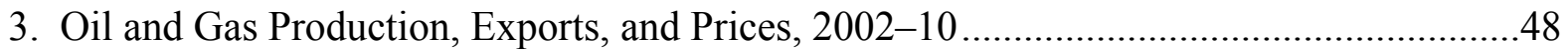

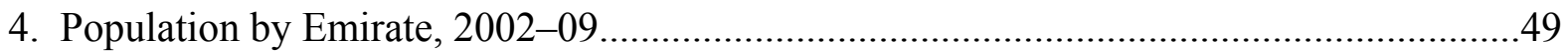

5. Sectoral Distribution of Civilian Employment, 2002-08 ………………….....................49

6. Consumer Price Index by Major Components, 2009-10 .................................................50

7. Consolidated Government Finances, 2002-10 ....................................................................

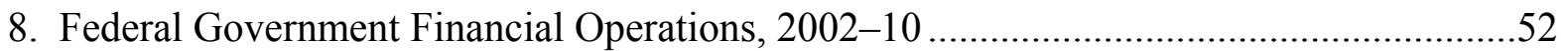

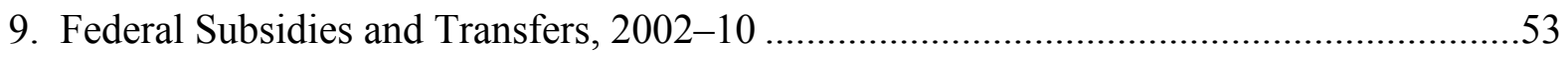

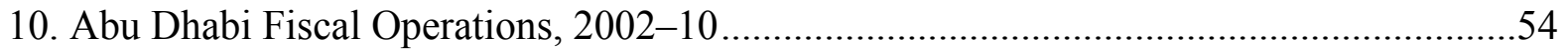

11. Abu Dhabi Development Expenditures, 2002-09 ………...........................................5

12. Abu Dhabi Government Transfers and Subsidies, 2002-09.........................................56

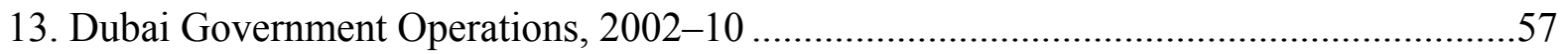

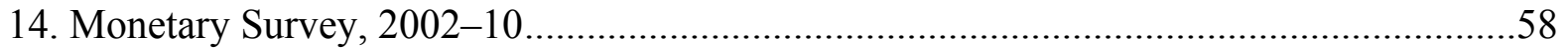

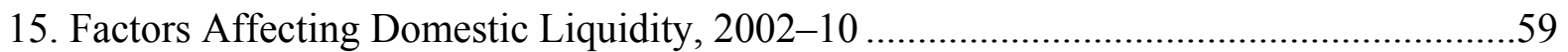

16. Summary Accounts of the Central Bank, 2002-10 ......................................................6

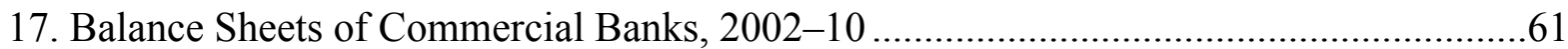

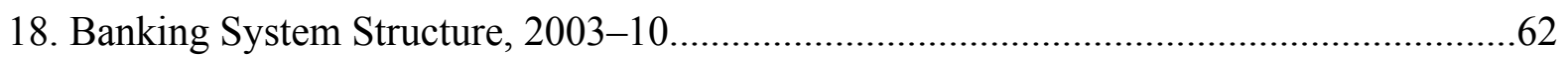

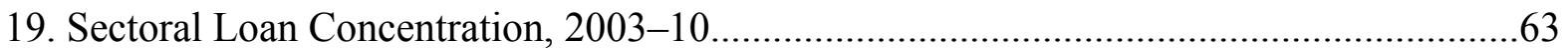

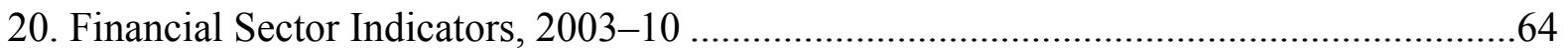

21. Banking System Income Statement and Profitability, 2003-10 …….............................65

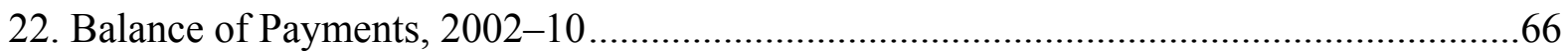

23. Merchandise Imports by Harmonized by System Sections, 2002-09 .............................67

24. Merchandise Exports by Harmonized System Sections, 2002-09 ....................................68 


\section{Risks Posed by Government-Related EnTITIES In THE UNITED ARAB Emirates ${ }^{1}$}

\section{A. Introduction}

1. Government-related entities (GREs) have been a major source of growth and development for the United Arab Emirates (U.A.E.) economy. The U.A.E. economy is dominated by a web of commercial corporations, financial institutions, and investment arms, owned directly by the Government of Dubai (GD), the Government of Abu Dhabi (GAD), or the ruling family under the umbrella of major holding companies (Figure I.1). Benefiting from government transfers and from extensive borrowing - in light of a perceived implicit government guarantee - in 2004-08, Dubai Inc. ${ }^{2}$ funded a major push into large-scale commercial and residential property developments. Dubai became a regional hub, and the economy achieved high growth rates. More recently, Abu Dhabi has also been developing major infrastructure projects through its GREs.

\section{The global financial and economic crisis has, however, unveiled the fiscal and} financial risks posed by GREs. Despite government support in 2008-09, the global financial crisis and the price correction in the local property market, combined with the maturity mismatch between short-term liabilities and long-term cash flows, forced Dubai World (DW), one of the main GREs in Dubai, to restructure its debt. The DW debt restructuring led to an increase in Dubai sovereign debt, with ramifications for the banking sector and financial markets. Other Dubai GREs are also in DW-style debt restructuring type negotiations with banks. ${ }^{3}$ There are also signs that some Abu Dhabi GREs heavily investing in the real estate sector are undergoing financial difficulties. ${ }^{4}$

\footnotetext{
${ }^{1}$ Prepared by Vincenzo Guzzo and Arthur Ribeiro da Silva.

${ }^{2}$ Dubai Inc. is the collection of enterprises and banks that are substantially owned and controlled by the GD, the Ruler of Dubai, or jointly. It does not include a number of joint holdings with Abu Dhabi (e.g., EMAL) or the Federal Government (e.g., Etisalat).

${ }^{3}$ In July 2010, Dubai Holding Commercial Operations Group (DHCOG), a subsidiary of Dubai Holding (DH) covering commercial operations in Dubai, secured a two-month extension on a US\$555 million loan, which was later allowed to further roll over twice through year-end. Later, press reports have indicated that DHCOG has reached an agreement, for which the revolving debt would be converted into a five-year loan. In November 2010, Dubai Group (DG), also a DH subsidiary with participations in financial services firms in Dubai and abroad, missed two scheduled loan payments worth US $\$ 1.8$ billion and started restructuring its US\$6.2 billion liabilities. In December 2010, Dubai International Capital (DIC), the investment arm of DH, has also successfully agreed with bank creditors to restructure US $\$ 2.5$ billion worth of bank loans: US\$2 billion would be extended to 2016 at 2 percent; US\$500 million extended to 2014 at an unchanged interest rate.

${ }^{4}$ In January 2011, the GAD stepped in with a US\$5.2 billion package to support Aldar, the Emirate's largest developer by market capitalization. In the context of this transaction, Aldar would sell about US\$3 billion worth of assets and place a US\$760 million convertible bond with another government-owned shareholder Mubadala.
} 
Figure I.1. Dubai Inc.

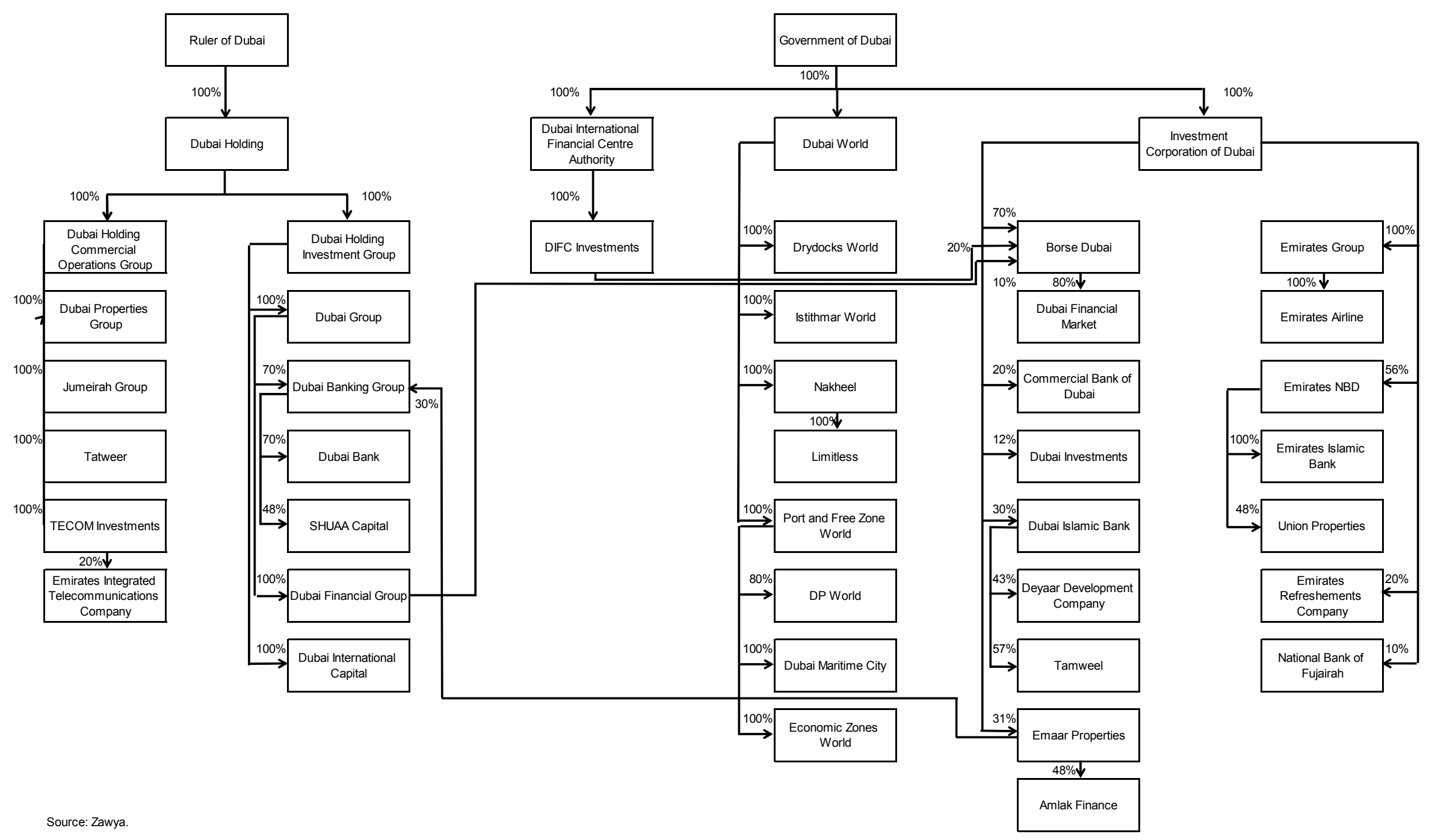




\section{Looking forward, GREs will likely continue to pose significant risks to the} sovereign balance sheet and the financial system. Although little information is available on the financial situation of most GREs, with an estimated US\$60 billion of debt due in 2011-12, the U.A.E. face rollover risk and would need to manage this carefully in light of continued turmoil in global markets. Moreover, with the restructuring of Dubai Inc., a significant amount of debt has been shifted to the medium term with potential bunching risks in 2014-15. The overhang in the real estate sector means that these risks can affect the sovereign balance sheet as contingent liabilities may materialize; they can affect local banks that hold GRE debt; and they can have broader implications for capital markets through higher cost of borrowing.

\section{The objective of this paper is to identify the risks posed by financially} underperforming GREs. The note will assess the impact of the Dubai debt restructuring on capital markets, the sovereign balance sheet, and the banking sector, and it will identify future potential risks, particularly in terms of contingent liabilities for the government.

\section{B. Which Types of Risks Emerged in the Context of Dubai's Debt Restructuring?}

\section{Market risk}

\section{Following the DW debt standstill announcement conditions in secondary markets} deteriorated rapidly. Yields on both conventional and Sukuk bonds immediately shot up by several hundreds of basis points. The extension of a US\$10 billion loan from the GD to DW had only a temporary impact and Dubai government bonds kept selling off through most of the first quarter of 2010 with yields peaking at over 10 percent. It was only with the submission of the restructuring plan in March 2010 and the subsequent agreement among a large number of creditors that yields entered a sustained downward trend, although they remain somewhat above pre-crisis levels (Figure I.2).

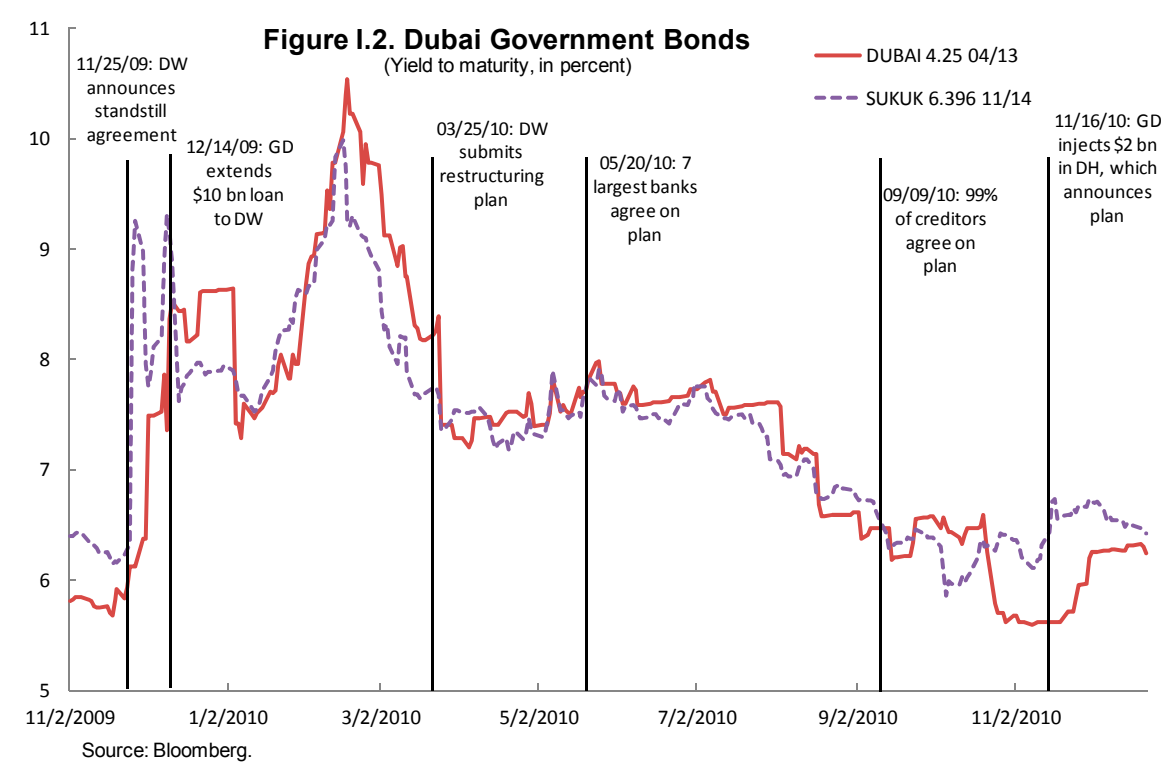




\section{Market access for the sovereign and the GREs themselves were significantly}

affected. Only, in September 2010, the GD regained market access, though at higher costs than its peers. In the post-DW issues, Dubai paid more than 120 basis points (over benchmark) compared to the same period a year earlier. Comparisons with peers indicate that Dubai issued at spreads comparable with sovereigns in the single B rating category, such as Ukraine (B+/B2/B), as highlighted in Table I.1. As for the GREs, in April 2010, the Dubai Electricity \& Water Authority (DEWA) had been the first Dubai's GRE to regain market access after the DW's announcement, but it had funded at over 8.6 percent on a US\$1 billion issue, to the tune of 300 basis points above similarly rated emerging market corporate issuers. Most Dubai's GREs have not still re-entered capital markets.

Table I.1. 2010 Select Sovereign Issues

\begin{tabular}{|c|c|c|c|c|c|c|c|c|c|}
\hline Sovereign & Date & $\begin{array}{l}\text { Value } \\
\text { (US\$ } \\
\text { million) }\end{array}$ & $\begin{array}{l}\text { Years to } \\
\text { Maturity }\end{array}$ & $\begin{array}{c}\text { Yield to } \\
\text { Maturity (\%) }\end{array}$ & $\begin{array}{c}\text { Currency } \\
\text { Code }\end{array}$ & $\begin{array}{c}\text { S\&P } \\
\text { Issuer } \\
\text { Rating }\end{array}$ & $\begin{array}{c}\text { Moodys } \\
\text { Rating }\end{array}$ & $\begin{array}{c}\text { Fitch } \\
\text { Issuer } \\
\text { Rating }\end{array}$ & $\begin{array}{c}\text { Spread to } \\
\text { USD } \\
\text { Benchmark } \\
\text { (bps) }\end{array}$ \\
\hline Belarus (B+) & 26-Jul-10 & 600 & 5 & 9.21 & USD & $\mathrm{B}+$ & B1 & & 727 \\
\hline Dubai & 29-Sep-10 & 500 & 5 & 6.81 & USD & & & & 543 \\
\hline Ukraine $(B+)$ & 16-Sep-10 & 500 & 5 & 6.99 & USD & $\mathrm{B}+$ & B2 & $B$ & 541 \\
\hline Dubai & 29-Sep-10 & 750 & 10 & 7.90 & USD & & & & 527 \\
\hline Ukraine $(B+)$ & 16-Sep-10 & 1,500 & 10 & 7.90 & USD & $\mathrm{B}+$ & B2 & $B$ & 499 \\
\hline Barbados (BBB) & 27-Jul-10 & 200 & 12 & 7.33 & USD & BBB & Baa3 & & 416 \\
\hline Lithuania (BBB) & 4-Feb-10 & 2,000 & 10 & 7.77 & USD & BBB & Baa1 & BBB & 402 \\
\hline Croatia (BBB) & 6-Jul-10 & 1,250 & 10 & 6.87 & USD & BBB & Baa3 & BBB- & 381 \\
\hline Dominican Republic (B) & 29-Apr-10 & 750 & 11 & 7.64 & USD & B & B1 & $\mathrm{B}$ & 377 \\
\hline Sri Lanka $(B+)$ & 27-Sep-10 & 1,000 & 10 & 6.35 & USD & $\mathrm{B}+$ & & $\mathrm{B}+$ & 373 \\
\hline Vietnam (BB) & 26-Jan-10 & 1,000 & 10 & 7.07 & USD & BB & Ba3 & BB- & 333 \\
\hline Lithuania (BBB) & 7-Sep-10 & 750 & 7 & 5.32 & USD & BBB & Baa1 & BBB & 320 \\
\hline Jordan (BB) & 8-Nov-10 & 750 & 5 & 4.17 & USD & BB & $\mathrm{Ba} 2$ & & 301 \\
\hline
\end{tabular}

Source: Dealogic.

\section{Fiscal risk}

7. The DW debt restructuring translated into higher sovereign debt. The Central Bank of the U.A.E. (CBU) extended a five year US\$10 billion loan to the GD in March 2009; the GAD extended a further US\$6.3 billion in December 2009 following the DW debt standstill. Our estimate of Dubai's government and government guaranteed debt stands at US\$36 billion at end-2010 (34 percent of 2010 Dubai and northern emirates GDP), up from US\$12.2 billion at the end of 2008 (Figure I.3). 
Figure I.3. Dubai: Total Debt Stock, 2007, 2010
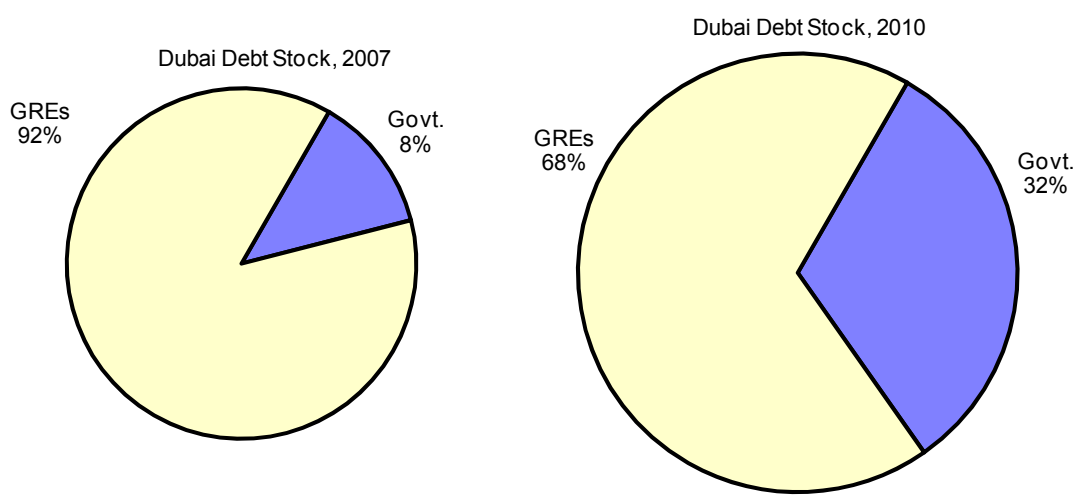

Source: Dealogic.

\section{Financial risk via local banks}

8. Dubai banks were affected by their exposure to GREs. The banking system's overall lending to Dubai GREs is estimated at 9 percent of total loans, and 16 percent of loans for Dubai banks. For DW, local banks were owed 40 percent of the debt subject to restructuring (US\$14.4 billion), of which 60 percent is concentrated in Dubai banks. Provisions on DW restructured loans have been completed and amount to US\$500 million, implying an average haircut of 9 percent. For Dubai Holding, the limited information available suggests that local banks are owed over 50 percent of the debt to be restructured (i.e. US\$5.2 billion), of which 90 percent is with Dubai banks.

\section{What Are the Main Risks Posed by the GREs Going Forward?}

\section{Sovereign debt is low both in Dubai and Abu Dhabi, but a large share of public}

debt stems from GREs. Dubai's publicly-held debt stands at US\$113 billion (102.5 percent of Dubai and northern emirates GDP). The bulk of this debt is from Dubai Inc. which accounts for US\$89.4 billion (Figure I.4) or 81.2 percent of Dubai and northern emirates GDP. Abu Dhabi's debt amounts to US\$104 billion (54.8 percent of Abu Dhabi GDP), and although the expansion of GREs started more recently, most of it also stems from GRE debt (US\$92.4 billion or 48.6 percent of Abu Dhabi GDP). 


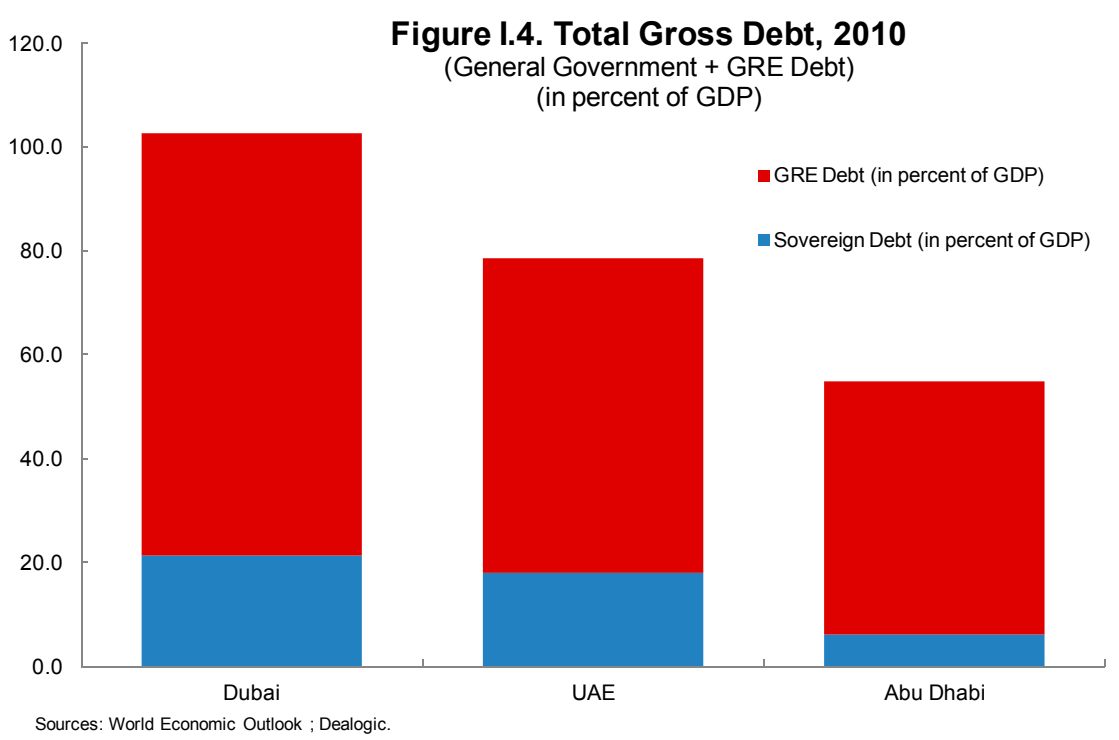

10. GRE debt is large by international comparisons. The size of Abu Dhabi's publicly-held sovereign debt is rather small (6.1 percent of Abu Dhabi GDP); Dubai faces a sovereign debt (excluding guarantees) of 21.4 percent of Dubai and northern emirates GDP, also far from large by international comparisons. It is only when the debt of the GREs is accounted for (Figure I.5) that the full scale of the problem becomes visible. On this metric, Abu Dhabi's debt rises to 54.8 percent of Abu Dhabi's GDP and Dubai's climbs to as much as 102.5 percent of GDP (Figure I.6).

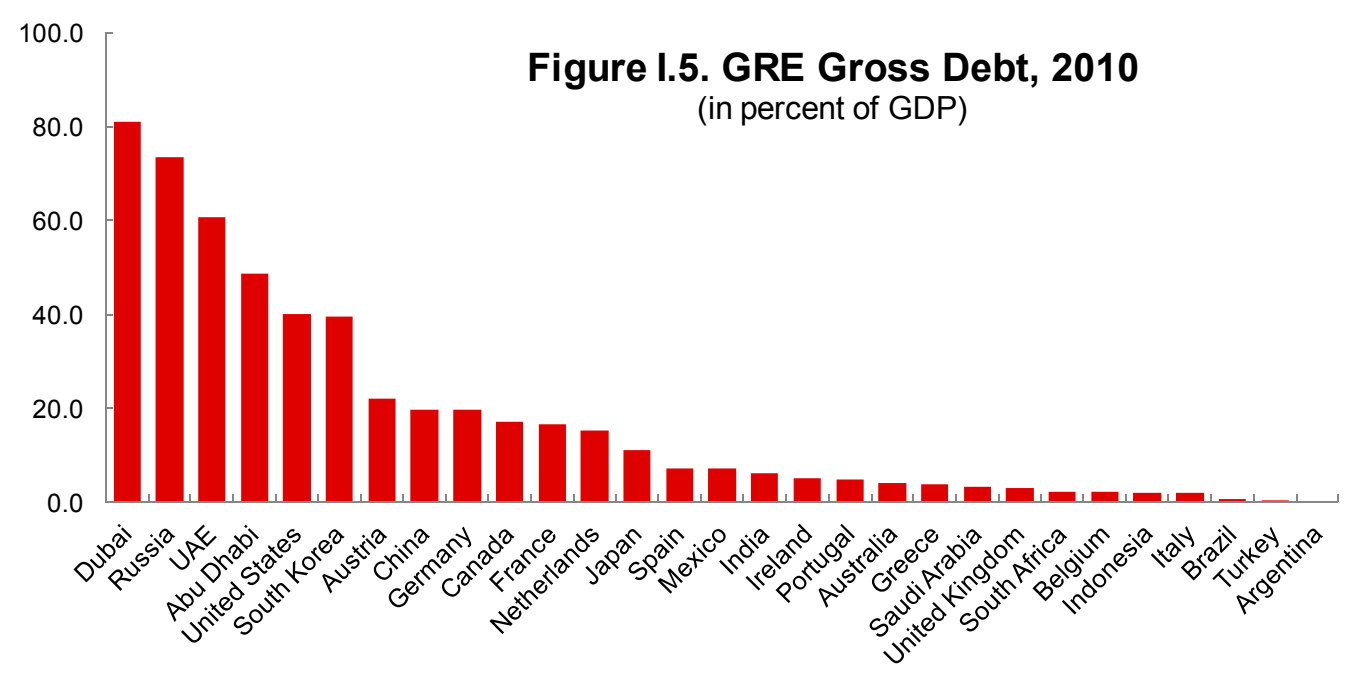

Sources: World Economic Outlook; Dealogic. 


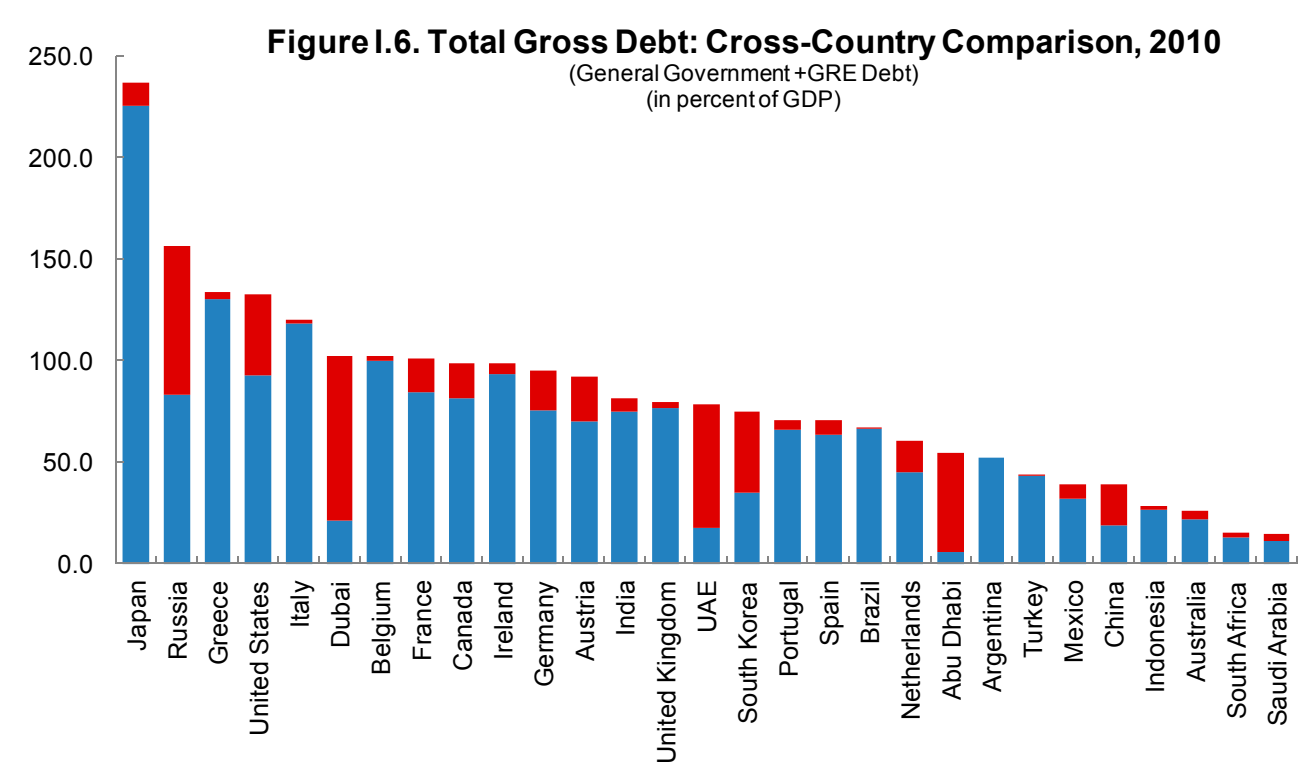

Sources: World Economic Outlook ; Dealogic.

11. With US\$60 billion maturing in 2011-12, both Dubai and Abu Dhabi face shortterm rollover risk. Our estimates suggest that US $\$ 31.2$ billion of Dubai's debt will come due in 2011-12 (Figure I.7), with DW and ICD accounting for US\$9.6 and US\$12 billion respectively (see Box I.1 and Table I.2 for details). Over \$27.6 billion of Abu Dhabi's debt will also come due in 2011-12 (Table I.3). Short-term roll-over risk may translate into a new shock in the cost of funding. The government and the corporates might have to roll over debt at a higher cost and, in extreme cases, because of exceptionally large increases in government funding costs, might not be able to refund at all, ultimately putting further strains on fiscal accounts and on the financial system.

Figure I.7. Maturity Profile of Dubai Inc. Debt, 2011-30

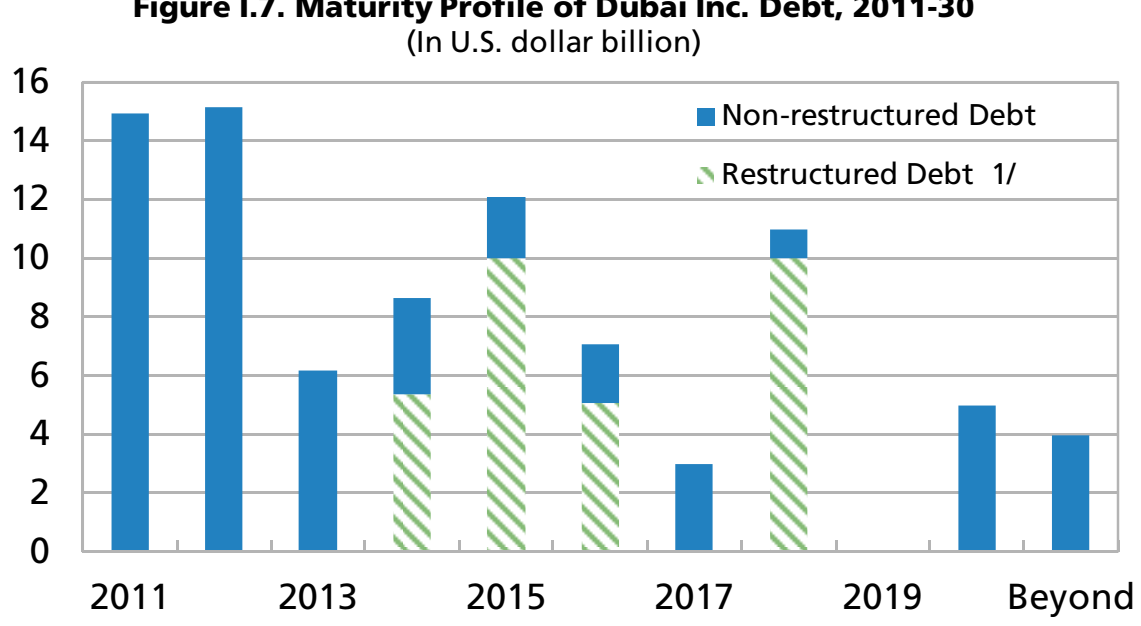

Sources: Dealogic; Bloomberg; country authorities; and Fund staff estimates.

1/ Preliminary estimates based on public information about Dubai Holding and other GRE ongoing debt restructurings, as well as Dubai World's completed restructuring; including debt guaranteed by the Dubai government. 


\section{Dubai faces more rollover risk in 2014-15, partly because of the bunching of}

the restructured debt. The restructured DW debt of US\$14.4 billion is split in two tranches, of US\$4.4 billion in 2015 and US\$10 billion in 2018. Thus, nearly half of DW's

US $\$ 36.1$ billion of debt is due in 2015 and beyond. Similarly, DH has US\$6.9 of its

US $\$ 14.4$ billion of debt due in 2015 and beyond, a good part of it being restructured debt. ICD has about US\$7 billion of its US\$22.2 total debt outstanding due in 2015 and beyond, mainly on account of Emirates Airline Group. Altogether, US $\$ 41.3$ billion or 37.5 percent of Dubai's stock of outstanding debt will come due in 2014-15, implying further potential refunding risk.

\section{Box I.1. Dubai Inc. Rollover Risk}

DW has US\$9.6 billion of debt maturing in 2011-12, or 27 percent of its total debt. Roughly $3 / 4$ of this debt is associated with DP World and Drydocks, i.e., not real-estate related. The rest is associated with Nakheel, Istithmar World, and Limitless, DW's private equity arm. The authorities have indicated that: (i) Nakheel bonds will be paid in full and on time; (ii) negotiations are on-going to extend the maturity of Nakheel loans on commercial terms; (iii) limitless does not need debt restructuring; and (iv) the private equity debt is located in Special Purpose Vehicles.

\section{DH has US\$2.7 billion of its debt due}

in 2011-12, about 20 percent of its total of US\$14.4 billion. DH is in negotiations with creditors on restructuring debt related to real estate and private equity ventures. Creditors have agreed to convert a US $\$ 555$ million facility from June 2010 into a five-year term loan. The GD has injected roughly US $\$ 2$ billion into the company, and has said it would do more if necessary. DIC, an investment arm of DH, restructured bank loans worth US\$2.5 billion, with US\$0.5 billion maturing in 2014 and the remaining US\$2 billion in 2016. Finally, DG has recently started to restructure US\$6.2 billion of bank loans.

More than half of ICD's debt, or US\$12 billion of the total US\$22.2 billion, matures in 2011-12. This debt is concentrated with the banks (Emirates NBD, Dubai Islamic Bank and Commercial Bank of Dubai) and with Emirates Airlines. This total also includes a US\$1 billion Emaar loan, and another US\$0.6 billion in DUBAL loans.

Other Dubai Inc. issuers have US\$5.7 billion due in 2011-12 (34 percent of the US\$16.7 billion total). These include US\$2.2 billion DEWA debt maturing in 2012, US\$1 billion for Department of Civil Aviation in 2011, and US\$1.25 billion from DIFC in 2012. 
Table I.2. Dubai: Publicly-Held Debt in the Form of Bonds and Syndicated Loans 1/2/ (In millions of U.S. dollars)

\begin{tabular}{clrrrrrrr}
\hline As of: December, 2010 & Debt Type & 2011 & 2012 & 2013 & 2014 & 2015 Beyond & Total \\
\hline \multirow{2}{*}{ Dubai World and subsidiaries } & & & & & & & \\
& Bonds & 750 & 2,043 & 0 & 350 & 3,200 & 3,600 & 9,943 \\
& Loans & 3,824 & 3,000 & 546 & 409 & 6,662 & 11,739 & 26,180 \\
& Total & 4,574 & 5,043 & 546 & 759 & 9,862 & 15,339 & 36,123
\end{tabular}

Dubai Holding and subsidiaries

$\begin{array}{lrrrrrrr}\text { Bonds } & 241 & 500 & 93 & 995 & 0 & 977 & 2,806 \\ \text { Loans } & 2,007 & 0 & 0 & 3,645 & 705 & 5,220 & 11,577 \\ \text { Total } & 2,248 & 500 & 93 & 4,640 & 705 & 6,197 & 14,383\end{array}$

Investment Corporation of Dubai and subsidiaries

$\begin{array}{lrrrrrrr}\text { Bonds } & 1,534 & 1,678 & 890 & 67 & 0 & 2,543 & 6,711 \\ \text { Loans } & 4,381 & 2,282 & 2,080 & 93 & 510 & 3,273 & 12,619 \\ \text { Total } & 5,915 & 3,960 & 2,970 & 160 & 510 & 5,816 & 19,330\end{array}$

Other Dubai Inc. 4/

\begin{tabular}{|c|c|c|c|c|c|c|c|}
\hline Bonds & 0 & 1,250 & 871 & 0 & 1,000 & $2,0003 /$ & 5,121 \\
\hline Loans & 1,581 & 2,639 & 1,100 & 3,090 & 0 & 2,163 & 10,573 \\
\hline \multirow[t]{2}{*}{ Total } & 1,581 & 3,889 & 1,971 & 3,090 & 1,000 & 4,163 & 15,694 \\
\hline & 14,318 & 13,391 & 5,580 & 8,649 & 12,077 & 31,515 & 85,530 \\
\hline Bonds & 0 & 750 & 599 & 0 & 0 & 220 & 1,569 \\
\hline Loans & 635 & 1,000 & 0 & 0 & 0 & 686 & 2,321 \\
\hline Total & 635 & 1,750 & 599 & 0 & 0 & 906 & 3,890 \\
\hline
\end{tabular}

Government of Dubai

$\begin{array}{lrrrrrrrr}\text { Bonds } & 0 & 0 & 1,770 & 20,479 & 0 & 0 & 6 / & 22,249 \\ \text { Loans } & 1,045 & 68 & 68 & 68 & 34 & 0 & 1,283 \\ \text { Total } & 1,045 & 68 & 1,838 & 20,547 & 34 & 0 & 23,532 \\ & 15,998 & 15,209 & 8,017 & 29,195 & 12,111 & 32,421 & 112,952 \\ & 14.5 & 13.8 & 7.3 & 26.5 & 11.0 & 29.4 & 102.6\end{array}$

Memorandum items:

Restructured Debt

Dubai Inc. banks

Government guaranteed 7/

Total GD including Guarantees

$\begin{array}{rrrrrrr}14.5 & 13.8 & 7.3 & 26.5 & 11.0 & 29.4 & 102.6 \\ 0 & 0 & 0 & 5,400 & 10,005 & 15,100 & 30,505 \\ 25,388 & 20,484 & 10,995 & 13,576 & 8,473 & 33,722 & 112,639 \\ 4,543 & 1,515 & 2,737 & 226 & 812 & 2,658 & 12,492 \\ 5,589 & 1,583 & 4,574 & 20,773 & 846 & 2,658 & 36,024\end{array}$

Sources: Dealogic, Zawya, Bloomberg, Dubai authorities, and Fund staff estimates.

1/ Excluding bilateral bank loans and accounts payable.

2/ Regardless of residency of debt holders.

3/ Assuming DEW A fully draws its receivables-securitization program under Thor Asset Purchase (Cayman) Ltd.

4/ Includes DEW A, DIFC, DAE, Borse Dubai, and others.

5/ Dubai GREs with government ownership below 50\% (Emaar, DIB, CBD).

6/ Assuming Abu Dhabi direct and indirect support is fully drawn.

7/ Mainly ICD holding level and DEWA debt, in addition to the governments'. 
Table I.3. Abu Dhabi: Publicly-Held Debt in the Form of Bonds and Syndicated Loans (In millions of U.S. dollars)

\begin{tabular}{|c|c|c|c|c|c|c|c|c|}
\hline As of: December, 2010 & Debt Type & 2011 & 2012 & 2013 & 2014 & 2015 & Beyond & Total \\
\hline \multicolumn{9}{|c|}{ Abu Dhabi Investment Council $1 /$} \\
\hline & Bonds & 1,540 & 896 & 365 & 1,933 & 1,148 & 1,942 & 7,824 \\
\hline & Loans & 1,000 & 882 & 400 & 0 & 0 & 40 & 2,322 \\
\hline & Total & 2,540 & 1,778 & 765 & 1,933 & 1,148 & 1,982 & 10,146 \\
\hline \multicolumn{9}{|c|}{ Abu Dhabi Water \& Electricity Authority 2/ } \\
\hline & Bonds & 99 & 1,500 & 1,993 & 1,000 & 0 & 3,412 & 8,004 \\
\hline & Loans & 3,150 & 0 & 989 & 0 & 213 & 7,796 & 12,148 \\
\hline & Total & 3,249 & 1,500 & 2,982 & 1,000 & 213 & 11,208 & 20,152 \\
\hline \multicolumn{9}{|l|}{ Etihad } \\
\hline & Bonds & 0 & 0 & 0 & 0 & 0 & 0 & 0 \\
\hline & Loans & 0 & 0 & 0 & 0 & 0 & 1,068 & 1,068 \\
\hline & Total & 0 & 0 & 0 & 0 & 0 & 1,068 & 1,068 \\
\hline \multicolumn{9}{|c|}{ International Petroleum Investment Company $3 /$} \\
\hline & Bonds & 0 & 0 & 0 & 0 & 1,000 & 1,500 & 2,500 \\
\hline & Loans & 2,434 & 850 & 4,359 & 0 & 0 & 0 & 7,643 \\
\hline & Total & 2,434 & 850 & 4,359 & 0 & 1,000 & 1,500 & 10,143 \\
\hline \multicolumn{9}{|c|}{ Mubadala Development Company 4/ } \\
\hline & Bonds & 19 & 0 & 0 & 1,250 & 0 & 1,699 & 2,968 \\
\hline & Loans & 0 & 0 & 5,300 & 0 & 0 & 8,482 & 13,782 \\
\hline & Total & 19 & 0 & 5,300 & 1,250 & 0 & 10,181 & 16,750 \\
\hline \multicolumn{9}{|c|}{ Tourism and Development Investment Company } \\
\hline & Bonds & 0 & 0 & 0 & 2,000 & 0 & 0 & 2,000 \\
\hline & Loans & 0 & 0 & 0 & 0 & 0 & 0 & 0 \\
\hline & Total & 0 & 0 & 0 & 2,000 & 0 & 0 & 2,000 \\
\hline \multicolumn{9}{|l|}{ Other Abu Dhabi Inc. 5/ } \\
\hline & Bonds & 0 & 0 & 0 & 0 & 0 & 0 & 0 \\
\hline & Loans & 0 & 0 & 0 & 500 & 0 & 150 & 650 \\
\hline & Total & 0 & 0 & 0 & 500 & 0 & 150 & 650 \\
\hline Other Loans & & & & & & & & 19,561 \\
\hline Total Abu Dhabi Inc. & & 11,502 & 7,388 & 16,666 & 9,943 & 5,621 & 29,349 & 80,470 \\
\hline \multicolumn{9}{|l|}{ Other Abu Dhabi Inc. 6/ } \\
\hline & Bonds & 2,589 & 470 & 1,021 & 1,250 & 0 & 0 & 5,330 \\
\hline & Loans & 2,554 & 1,425 & 0 & 640 & 0 & 1,951 & 6,570 \\
\hline & Total & 5,143 & 1,895 & 1,021 & 1,890 & 0 & 1,951 & 11,900 \\
\hline \multicolumn{9}{|l|}{ Government of Abu Dhabi } \\
\hline & Bonds & 0 & 1,000 & 0 & 1,500 & 0 & 1,500 & 4,000 \\
\hline & Loans & 335 & 214 & 310 & 311 & 312 & 5,670 & 7,152 \\
\hline & Guarantees & & & & & & & 490 \\
\hline & Total & 417 & 1,296 & 392 & 1,893 & 394 & 7,252 & 11,642 \\
\hline Total Abu Dhabi Debt & & 17,062 & 10,579 & 18,079 & 13,726 & 6,015 & 38,552 & 104,012 \\
\hline In percent of Abu Dhe & bi 2010 GDP & 9.0 & 5.6 & 9.5 & 7.2 & 3.2 & 20.3 & 54.8 \\
\hline
\end{tabular}

Sources: Dealogic, Zawya, Bloomberg, Abu Dhabi authorities, and Fund staff estimates.

1/ Includes ADCB, NBAD, UNB

2/ Includes TAQA \& US $\$ 6.6$ billion non-recourse debt for IWPP

3/ Includes US\$2.5 billion Nov issuance

4/ Includes Dolphin, EMAL

5/ Includes ADPC, GHC

6/ Below 50 percent government-owned entities; include Aldar, FGB, NCCC, Sorouh. 


\section{Which GREs are Currently the Main Sources of Contingent Risk?}

\section{Currently, several GREs pose contingent risk to the sovereign balance sheet. ${ }^{5}$}

Over the past few years, GREs have been offered what the market perceived as implicit guarantees and, lately, actual transfers have been made to support specific companies. Several GREs seem to be lacking sufficiently strong governance structure. For most nonlisted GRE annual reports are not published, including audited balance sheets and income statements. Information on off-balance sheet liabilities is often unavailable and so are data about overall activity, employment, and investment. On this ground, several GREs in Dubai (e.g. some subsidiaries of DW and DH and few ones in ICD) and Abu Dhabi should be regarded as sources of risk for the sovereign balance sheet.

\section{The deterioration in the financial conditions of some GREs point to continued}

risk. Bottom-up analysis of available GREs' financial statements reveals areas of profitability — albeit eroding from a year earlier — countered by outright losses for several real estate companies and some financial services entities (Tables I.4 and I.5). ${ }^{6}$ For Dubai GREs, profit margins, computed as net profits over operating revenues or interest income (in the case of conventional financial institutions) or income (for Islamic banks), were down to a ratio of -0.17 in the third quarter of 2010 from 0.18 a year earlier on a set of 15 companies. It is worth pointing out, however, that the largest losses were concentrated in DCHOG. Once this entity is excluded, profit margins were actually slightly up from a year earlier. In Abu Dhabi, average profit margins for a sample of 18 GREs were slightly down, the main exception being Mubadala, which benefited from significant government capital injections during the period under consideration.

\footnotetext{
${ }^{5}$ The assessment of the risk posed by a public enterprise is based on a set of criteria, which include managerial independence, relations with the government, governance structure, financial conditions and sustainability, and several other factors. The criteria could be further broken down in more specific areas of performance: Managerial independence: (1) pricing; (2) employment policies; Relations with the government; (3) subsidies and transfers; (4) quasi-fiscal activities; (5) the regulatory and tax regime; Governance structure; (6) periodic outside audits; (7) publication of comprehensive annual reports; (8) shareholders' rights; Financial conditions and sustainability; (9) market access; (10) less than full leveraging; (11) profitability; (12) record of past investments; and Other risk factors; (13) vulnerability; and (14) importance.

${ }^{6}$ The bottom-up analysis of the GREs' financial statements aims to assess the financial performance of a selected number of GREs that account for a relevant share of total actual and contingent liabilities for the sovereign. The information gathered is rearranged into ratios capturing the main areas of financial performance and compared to that observed over the same quarter a year earlier. The analysis focuses on the extent to which the GREs rely on debt financing (leverage) and on their ability to generate earnings (profitability).
} 
Table I.4. Dubai GREs: Select Indicators

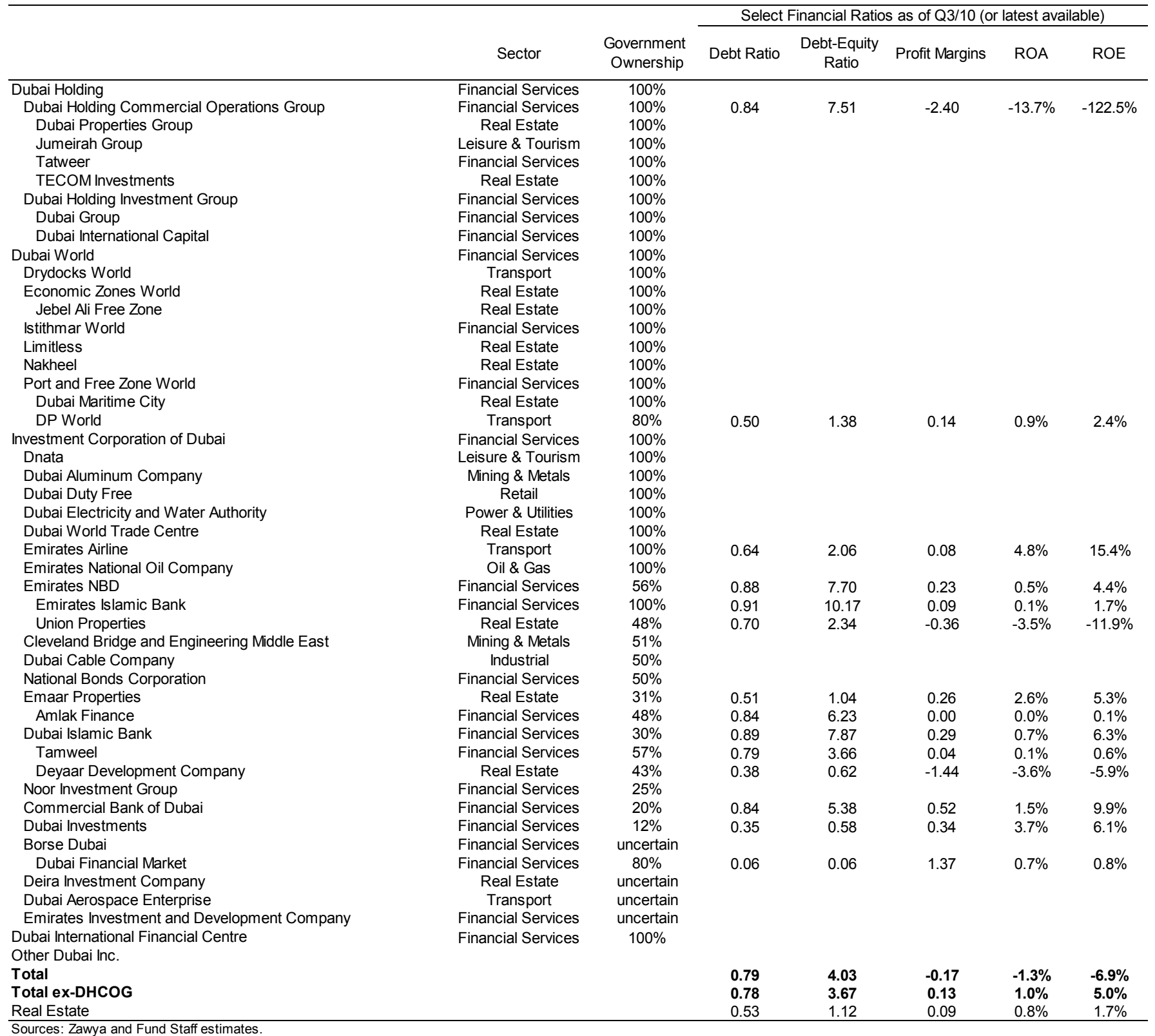


Table 5. Abu Dhabi GREs: Select Indicators

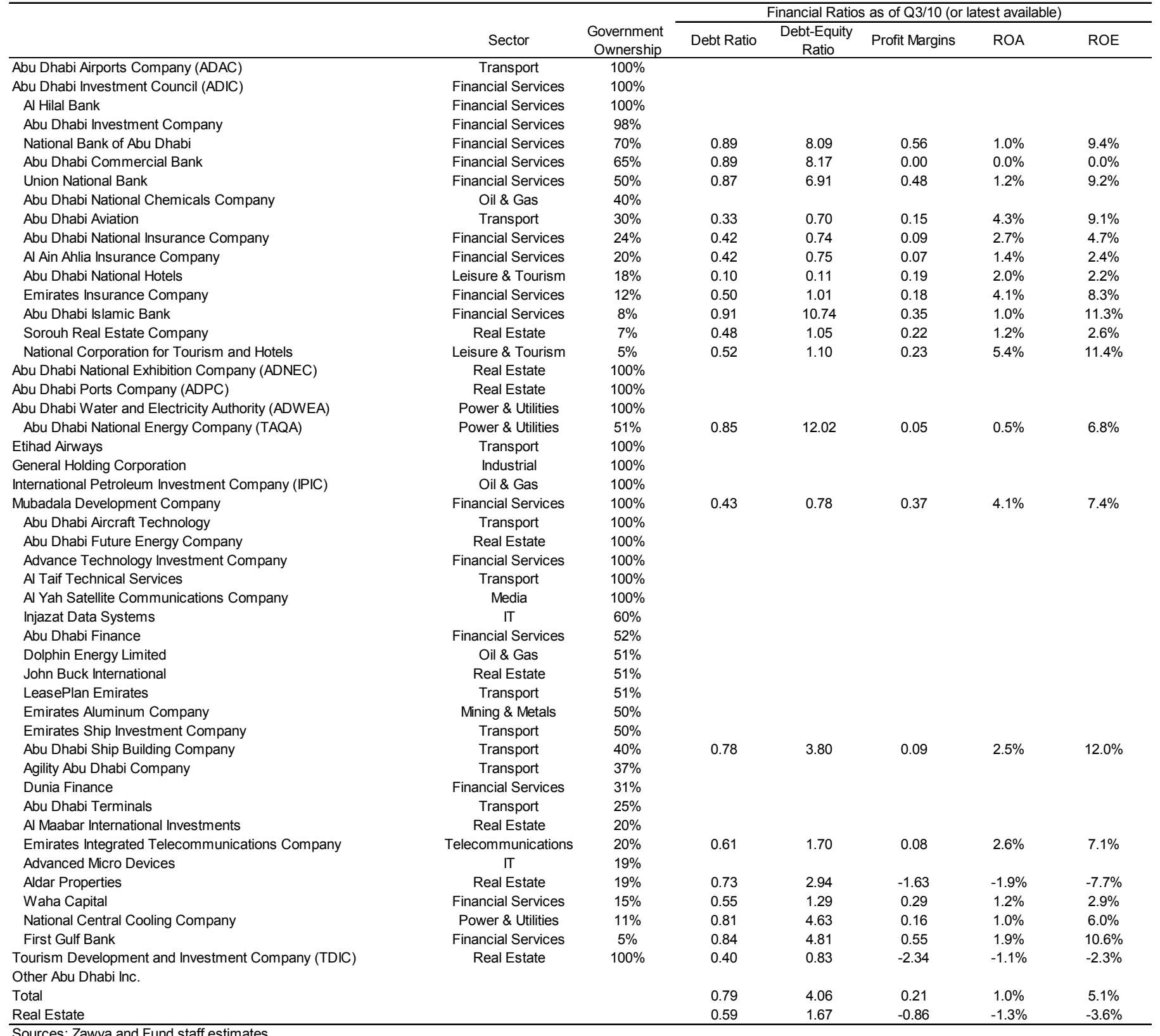


15. GREs in the real estate sector face significant financial constraints. Five real estate GREs are included in the sample. These are Aldar Properties, Sorouh Real Estate, and TDIC for Abu Dhabi; Deyaar Development Company, Emaar Properties, and Union Properties for Dubai. In aggregate, this set of companies posted net losses worth AED 0.9 million in the third quarter of 2010. Aldar Properties, Deyaar Development Company, TDIC and Union Properties posted losses, and Sorouh Real Estate reported a significant contraction in profits from a year earlier. The sector's performance would have been much worse if Emaar Properties had not recorded major progress in the period under consideration.

\section{Regional comparisons confirm the problems faced by the Emirati GREs} operating in the real estate sector. The losses reported by real estate companies in Dubai and Abu Dhabi are in stark contrast with the financial performance registered by several regional peers. Table I.6 compares the performance of five UAE real estate GREs and five large companies operating in the same sector in Qatar, Saudi Arabia, and Egypt as of the third quarter of 2010 (or latest available). The average profit margin ratio for the latter group is +0.39 , while the same ratio for U.A.E. GREs is -0.03 . The discrepancy is even larger, if Emaar is excluded from the sample. ROA and ROE highlight similar dynamics. Also, U.A.E. GREs tend to exhibit higher leverage ratios than their regional peers.

Table I.6. U.A.E. Real Estate GREs vs. Regional Peers: Select Indicators

\begin{tabular}{|c|c|c|c|c|c|c|}
\hline & \multirow[b]{2}{*}{ Country } & \multicolumn{5}{|c|}{ Select Financial Ratios as of Q3/10 (or latest available) } \\
\hline & & Debt Ratio & $\begin{array}{c}\text { Debt-Equity } \\
\text { Ratio }\end{array}$ & $\begin{array}{l}\text { Profit } \\
\text { Margins }\end{array}$ & ROA & ROE \\
\hline ALDAR Properties & U.A.E. & 0.75 & 3.00 & -1.63 & $-1.9 \%$ & $-7.7 \%$ \\
\hline Barwa Real Estate Company & Qatar & 0.83 & 5.26 & 1.29 & $0.9 \%$ & $5.7 \%$ \\
\hline Company & Saudi Arabia & 0.38 & 0.64 & 0.36 & $3.7 \%$ & $6.1 \%$ \\
\hline Deyaar Development Company & U.A.E. & 0.39 & 0.62 & -1.44 & $-3.6 \%$ & $-5.9 \%$ \\
\hline Emaar Properties & U.A.E. & 0.51 & 1.04 & 0.26 & $2.6 \%$ & $5.3 \%$ \\
\hline Ezdan Real Estate Company & Qatar & 0.13 & 0.15 & 0.54 & $0.4 \%$ & $0.5 \%$ \\
\hline Sorouh Real Estate Company & U.A.E. & 0.54 & 1.17 & 0.22 & $1.2 \%$ & $2.6 \%$ \\
\hline Talaat Mostafa Group Holding & Egypt & 0.54 & 1.20 & 0.19 & $1.2 \%$ & $2.7 \%$ \\
\hline Union Properties & U.A.E. & 0.70 & 2.37 & -0.36 & $-3.5 \%$ & $-11.9 \%$ \\
\hline United Development Company & Qatar & 0.64 & 2.08 & 0.55 & $3.2 \%$ & $10.3 \%$ \\
\hline Total U.A.E. Real Estate GREs & & 0.61 & 1.57 & -0.03 & $-0.2 \%$ & $-0.4 \%$ \\
\hline Total U.A.E. Real Estate GREs ex-Emaar & & 0.68 & 2.09 & -0.58 & $-1.9 \%$ & $-5.9 \%$ \\
\hline Total Regional Peers & & 0.56 & 1.32 & 0.39 & $1.4 \%$ & $3.3 \%$ \\
\hline
\end{tabular}

Sources: Zawya; and Fund staff estimates.

\section{At least US\$20 billion of contingent liabilities may stem from GREs in Dubai}

and Abu Dhabi. Not all GREs should be seen as sources of sovereign risk, but, most entities operating in the real estate sector appear to be falling in this category, given the weak performance of the sector. Accordingly, if we assume that all debt issued by real estate GREs or their subsidiaries, together with that of those entities currently reporting losses, will be a 
contingent liability in the sovereign balance sheet, at least US\$20 billion of contingent risk can be foreseen for Dubai and Abu Dhabi, with over half of that debt coming due in 2011-12.

18. There are several caveats to this estimate. First, other companies, primarily nonlisted entities, which do not disclose financial statements, may also be registering losses. Second, the performance of profitable companies operating outside the real estate sector may also be subject to deterioration over the coming years, ultimately triggering sovereign support. Third, for several GREs, the liabilities requiring sovereign support may exceed significantly the level of publicly held debt. Finally, sovereign support may well go beyond guaranteeing the stock of outstanding liabilities and requiring capital injection. While all these factors should be taken into account when assessing the perimeter of contingent risk, on a more positive note, the net impact of these companies on the sovereign balance sheet might also turn out to be lower when assets are accounted for.

\section{Local banks appear prepared to absorb losses on exposures to GREs operating} in the real estate. A staff stress test assumes that local banks need at least 16 percent capital adequacy to stay in line with regional peers. Under this assumption, banks could take a 90 percent write-down on the estimated US\$20 billion debt of both Dubai and Abu Dhabi GREs operating in the real estate sector or reporting outright losses. If one focuses on Dubai only, the local banks could take a 25 percent write-down on all Dubai nonbank GRE debt of around US $\$ 70$ billion. These are rough system-wide estimates based on publicly available information that generally excludes bilateral bank loans.

\section{E. Policies to Manage GRE Risk}

\section{The U.A.E.'s stock of government debt is relatively low, but GREs pose} significant contingent risk on the emirates' sovereign balance sheets. The size of U.A.E.'s publicly-held government debt is rather small. It is only when the debt of the GREs is accounted for that the full scale of the risk faced by the sovereign balance sheet becomes visible, as well as its potential implications for the domestic banking sector and debt capital markets.

\section{Most GREs operating in the real estate sector should be seen as sources of} sovereign risk. Financial conditions vary considerably across companies. Bottom-up analysis of GREs' financial statements reveals outright losses for several real estate companies and some financial services entities.

22. Furthermore, with US\$60 billion maturing in 2011-12, both Dubai and Abu Dhabi face short-term rollover risk. Short-term roll-over risk may translate into a new shock in the cost of funding. The government and the companies might have to roll over debt at a higher cost and, in extreme cases, because of exceptionally large increases in government funding costs, might not be able to refund at all, ultimately putting further strains on fiscal accounts and on the financial system. 


\section{The recent GRE bailouts and the expansion of GRE borrowings in several} emirates underscore the need to have a proper risk management framework for GREs. Such a framework entails assessing, monitoring, and reporting of contingent liabilities arising from the GREs, and transparent reflection of GRE contingent liabilities in government accounts. To this end, the debt management offices should have dedicated units collecting frequent data on GRE outstanding liabilities, their maturity profile, income and cash-flow statements, and assessing potential contingent liabilities to the sovereign. The authorities should also consider including a statement of this contingent risk as part of the annual budget documents, including discussion of past experiences, forward-looking estimates as well as a presentation of as well as risk mitigation strategies.

\section{Containing GRE borrowing is a pre-condition for fiscal sustainability and} financial stability at the emirate level and requires a strong institutional framework. With nearly US\$60 billion of debt expected to mature over these two years, governments and corporates might have to roll over debt at a higher cost and, in extreme cases, because of exceptionally large increases in government funding costs, might not be able to refund at all, ultimately putting further strains on fiscal accounts and on the financial system. In order to contain further risk-taking, the authorities should consider introducing a mechanism to manage GRE borrowing (including through setting limits on changes in GRE borrowings or overall GRE liabilities) to avoid sustainability problems emerging from these entities over the medium term. Any GRE borrowing at the emirate level would then require the assent of the emirate finance department. This would provide a strong signal of debt sustainability and broader financial market stability.

\section{Improved corporate governance and transparency are also key for mitigating} the risks posed by GREs. An assessment of corporate governance against the OECD standard would be useful. In particular, it would be important to delineate clearly between the commercial and noncommercial operations carried by GREs, clarify the government support strategy to the GREs, and standardize the accounting, auditing, and financial reporting practices of GREs. The GAD has made important progress in this area by disclosing the list of GREs that it would support and including explicit transfer in the budget for the noncommercial operations of the GREs. Better information disclosure about GRE financial accounts would also help attract investors and ultimately translate into lower funding costs. 


\section{Ensuring Financial Sector StabiLITy In the United ARAB EMIRATeS ${ }^{7}$}

\section{A. Introduction}

26. Dubai embarked on large-scale property development and overseas investments to accelerate the diversification of its economy that led to boom and subsequent bust. Given the scale of financing needed relative to the small local banking system, Dubai's GREs borrowed abroad in the form of syndicated loans, bonds and Islamic sukuks (Figure II.1). Consequently, the surge in Dubai foreign borrowing led to significant roll-over risk (Figure II.2).

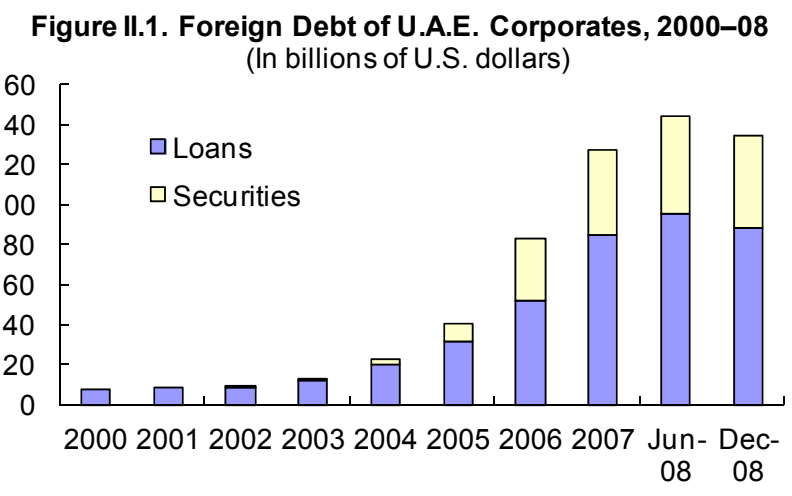

Sources: JEDH.org and Fund staff estimates and calculations.
Figure Il.2. Foreign Roll-Over Needs of Corporates, 2001-08

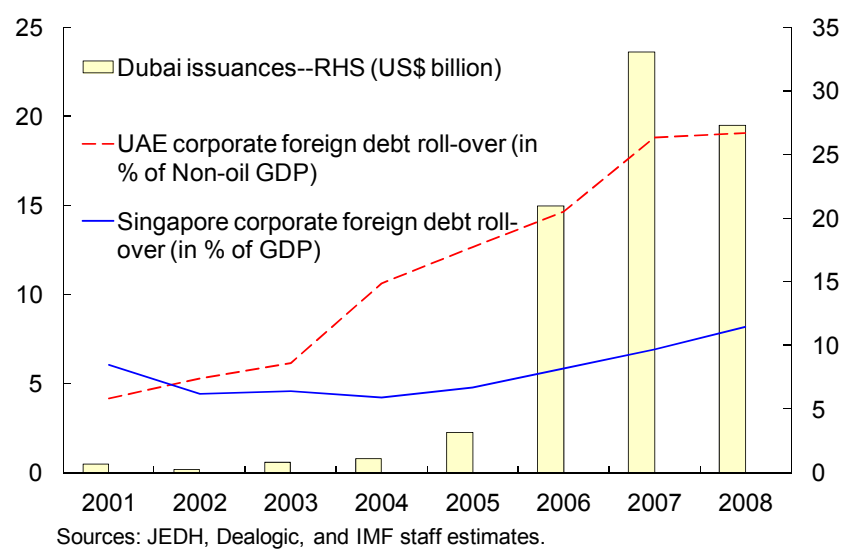

27. The U.A.E. banking sector played a role in the overheating cycle of Dubai. Domestic credit expanded on average at 40 percent per year during 2004-08, much above trend (Figure II.3) and out of line with other emerging markets (Figure II.4). At the same time, capital dropped from 19 percent of risk-weighted assets in 2003 to 13 percent in 2008. The credit surge, encouraged by negative real interest rates, went mainly to the suppliers of Dubai GREs and personal loans for business purposes (name lending).

Figure II.3. U.A.E.: Excess Credit, 1992-2008

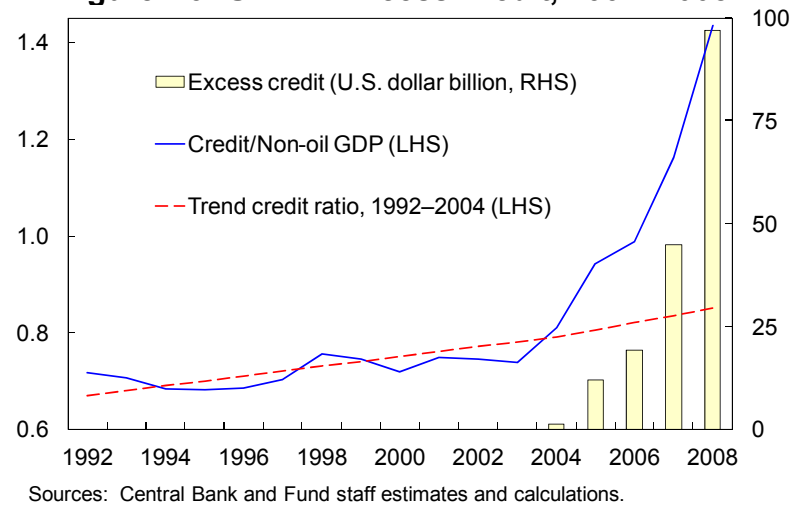

Figure II.4. Credit Growth and Capital Adequacy

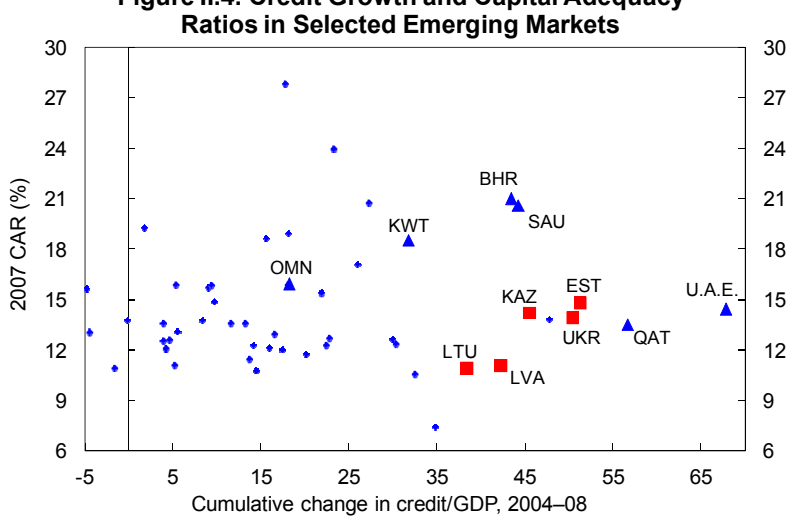

Source: Fund staff estimates.

\footnotetext{
${ }^{7}$ Prepared by Gabriel Sensenbrenner. Based on aggregate banking data up to end-December 2010.
} 
28. Short-lived speculative deposit inflows amplified the end of the cycle. The growing differential with U.S. inflation encouraged speculative bets on a currency appreciation starting in mid2007, in the form of deposits in local banks. These reversed abruptly in the second quarter of 2008 when it became clear that the commitment to the peg was strong. By then, loan/deposit ratios had risen above 100 percent (Figure II.5). ${ }^{8}$ The U.A.E. deposit base is skewed toward deposits from large corporates, as wage earners are primarily expatriates that remit

Figure II.5. U.A.E. Local Banks Capital and Liquidity Buffers, 2002-09

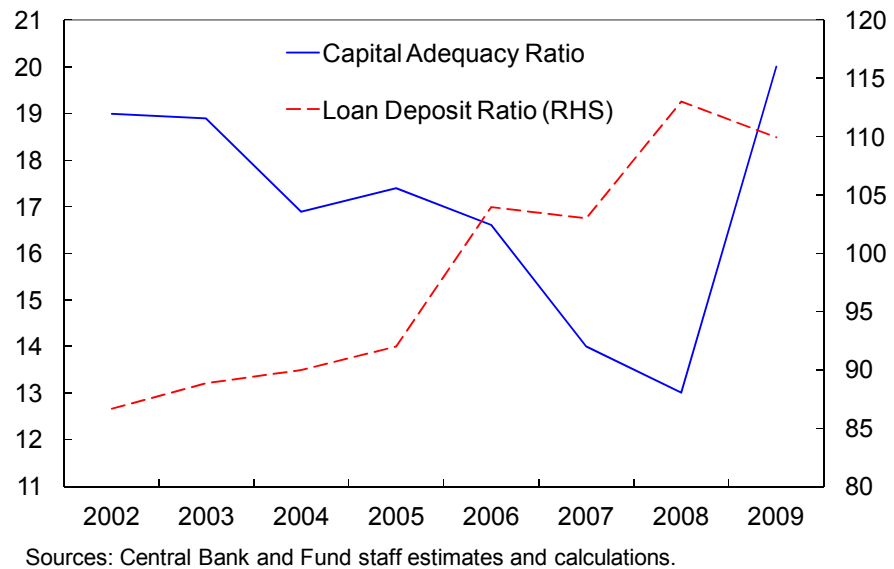
earnings abroad.

29. Looking forward, banks and the authorities need to prepare for aftershocks emanating from Dubai and the broader real estate sector. On-going debt restructurings in the Dubai GREs as well as further nonperforming loans (NPLs) from still falling property values will require more provisions and continue to dampen profitability, more so in Dubai banks than in Abu Dhabi banks. Banks with a greater proportion of restructured loans in their books should also be prepared to absorb the roll-over risk as these loans start to mature, and the scheduled decline in government capital support starting in 2012. Finally, banks will need to lengthen the maturity of their funding and improve its stability in light of the Basel III liquidity requirements.

30. The paper is organized as follows: Section B provides an overview of the policy responses to the crisis. Section $\mathrm{C}$ discusses current conditions and remaining vulnerabilities of the banking system. Section D highlights the main risks facing the system. Section E discusses policies to ensure the stability of the system.

\footnotetext{
${ }^{8} \mathrm{CBU}$ regulations impose a ceiling of 100 percent on the loan to stable resources ratio, where stable resources are defined as 85 percent of deposits plus market funding above six months.
} 


\section{B. Policy Responses to the Crisis}

\section{The crisis had three main phases:}

- The reversal of deposit inflows in the second quarter of 2008 and the correction in Dubai property prices (Figure II.6).

- $\quad$ The sharp increase in Dubai borrowing costs after Lehman Brothers (in the fourth quarter of 2008; Figure II.7) and the sudden shut-down of international debt markets for Dubai borrowers (Figure II.8).

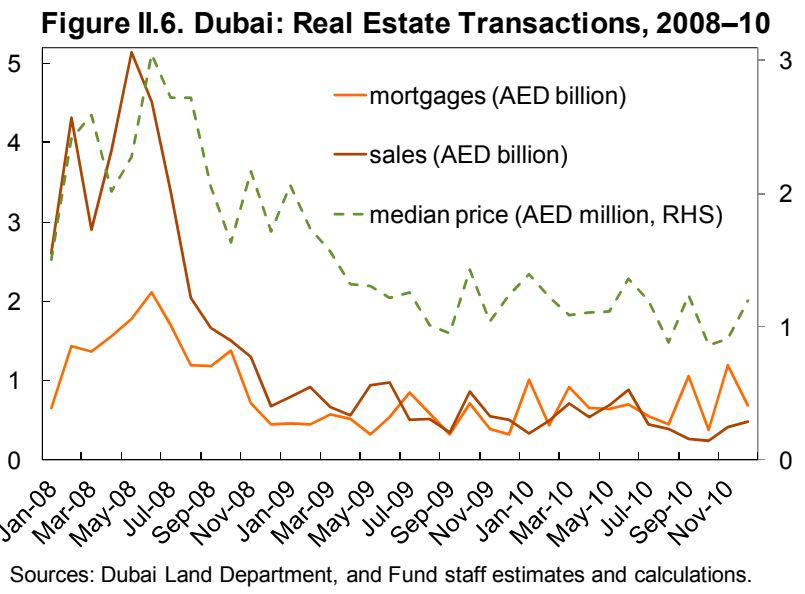

The Dubai World debt restructuring at the end of 2009.
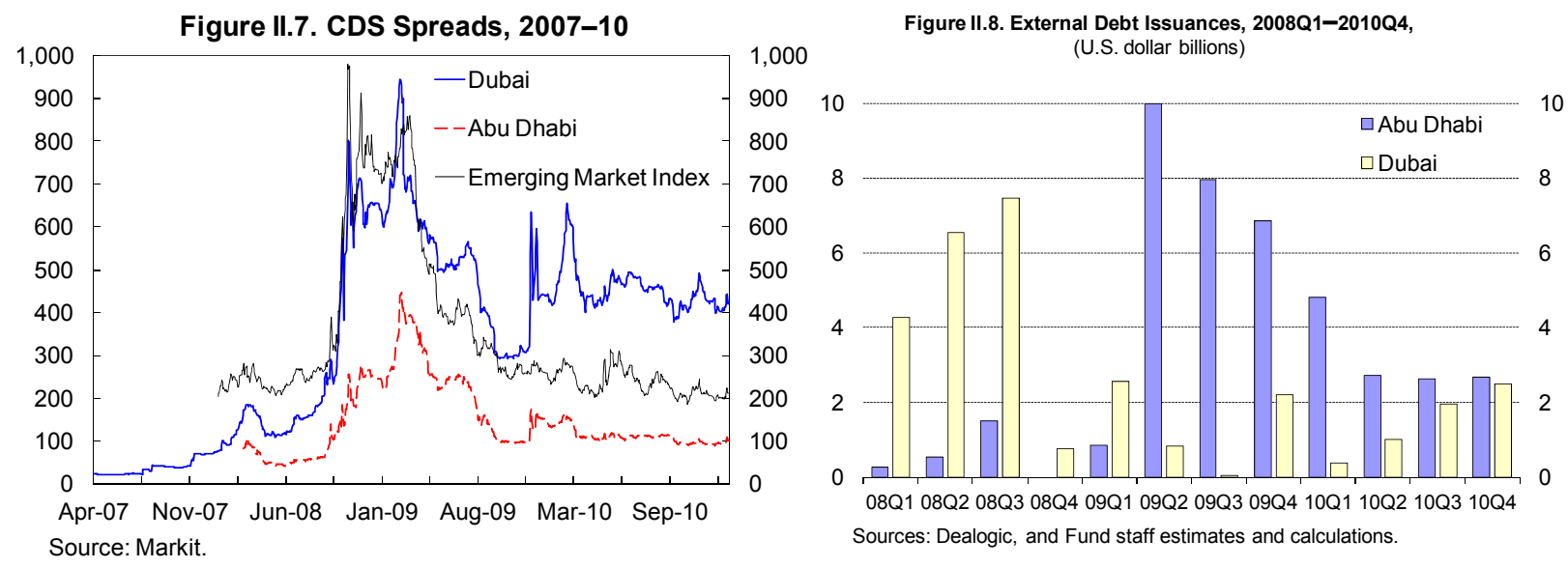

32. The authorities took swift action in 2008 and early 2009 to support the local banks.

- $\quad$ The CBU provided liquidity support (repos) to help banks handle the sharp reversal of deposit inflows, as seen in the drop of banks' holdings of central bank CDs. By end2008, central bank repos were replaced by government deposits funded by an AED 70 billion loan from the CBU to the federal government (Figure II.9).

- $\quad$ The authorities also recognized quickly that capital ratios of 13 percent would be too low in the new environment. A plan was put in place to boost capital. In the event, capital adequacy rose to 19 percent by mid-2009, a combination of tier 1 capital from emirate 
governments and conversion of federal and emirate government term deposits into tier 2 capital (Figure II.10). ${ }^{9}$

- A three-year blanket guarantee on bank liabilities was introduced. This guarantee has not been formalized and there is no levy on banks into an insurance fund.

Figure II.9. Bank Liquidity and CBU Support, 2007-10

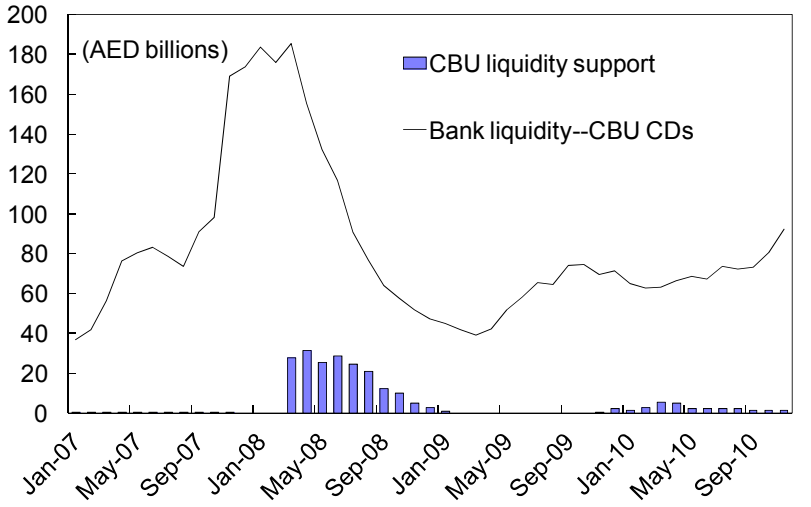

Figure II.10. GCC Bank Support Packages, 2008-09

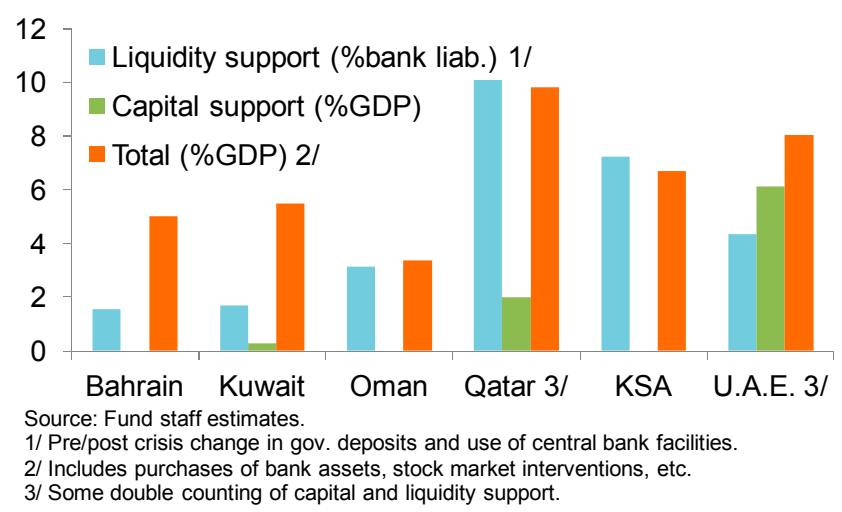

Sources: Central bank and Fund staff estimates and calculations.

\section{The local banks also benefitted from various official loans to the GD, which} benefited Dubai GREs, including Dubai World. The central bank bought a $\$ 10$ billion bond from the GD in the first quarter of 2009 which the GD lent on to its GREs. However, it became clear by the end of 2009 that most Dubai borrowers would not regain market access at reasonable cost. Abu Dhabi provided further loans to GD after Dubai World called a debt standstill in November 2009. The central bank and Abu Dhabi loans helped the GREs maintain some payment to contractors and suppliers and keep interest payments on bank loans current, thereby minimizing provisioning while negotiating debt restructuring. The restructuring deal for Dubai World that was agreed in mid-2010 allowed key developers to resume some activity and payments to the supply chain.

\footnotetext{
${ }^{9}$ Tier 1 support amounted to \$4 billion (mainly Abu Dhabi) and tier 2 was $\$ 16$ billion.
} 


\section{The DW debt restructuring has generated limited provisioning requirements for} local banks. The DW

restructuring has been used as a

Figure II.11. Maturity Profile of Dubai GRE Debt, 2011-30 template for other GREs. In broad terms, the template involves senior creditors extending principal by several years and haircuts that depend on a menu of interest rate options - the haircuts translate into net present value (NPV) losses that are recognized upfront as specific provisions under IFRS. In exchange, the GD increased its equity in the (In U.S. dollar billion)

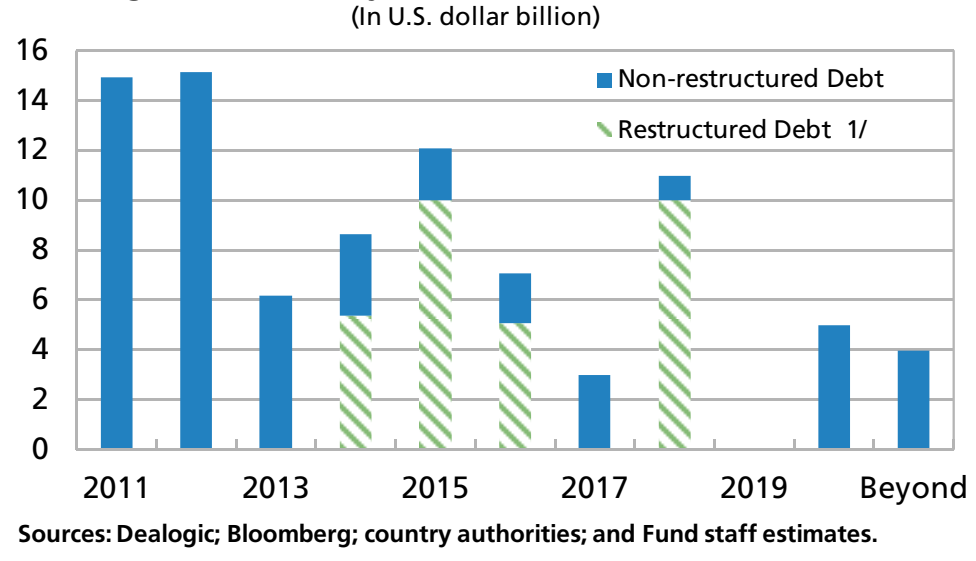

1/ Preliminary estimates based on public information about Dubai Holding and other GRE ongoing debt restructurings, as well as Dubai World's completed restructuring; including debt guaranteed by the Dubai government. companies. Bonded debt is paid in full and on time to minimize coordination delays and ensure that negotiations can focus on the larger bank debt. As a result, more than $\$ 30$ billion of Dubai GRE debt has been shifted from 2010-11 to 2014-18 (Figure II.11). Provisions for NPV losses for DW restructured loans amount to AED 1.8 billion for local banks, about 9 percent of the value of their exposure. It is expected that NPV losses/provisions on on-going GRE debt restructuring could be somewhat higher.

\section{Current Conditions and Vulnerabilities}

35. Although strong government backing is viewed as a source of strength in the current environment, the large public ownership of banks raises governance issues. Rating agencies consider that banks' intrinsic financial strength is moderate to weak, in line with other banks in the GCC. However, overall financial strength, taking into account Figure II.12. Government Ownership of Banks the presumption of government support, is the highest. Local banks are controlled substantially by governments, ruling families, or GREs, with the exception of one of the 10 largest banks, which is (Percent of assets) owned by a Dubai merchant family. Banks majority-owned by the public sector control 75 percent of local banking assets - 90 percent when including substantial minority shareholdings (Figure II.12). The central bank has regulatory caps on related-party and large exposures, but some banks have reportedly obtained exemptions. The international experience indicates that large public ownership dulls the incentives of management to protect the interests of the bank and minority shareholders. It can also distort the incentives of supervisors. It is worth noting that no bank has ever failed in the U.A.E. 


\section{The concentration of lending to GREs creates vulnerabilities for Dubai banks.}

Under conservative assumptions, an estimated 16 percent of Dubai banks' loans are to Dubai GREs; 4 percent for Abu Dhabi banks. Dubai banks show already NPL ratios almost twice as high as Abu Dhabi banks. NPLs would be higher if GRE restructured loans were classified systematically as nonperforming; DW and Dubai Holding restructured loans would push the system-wide NPL ratio from 6 percent (November 2010) to 10 percent. ${ }^{10}$ Exposure to GRE debt increases the potential for debt restructuring, hence for more provisions in 2011.

37. Exposure to real estate is higher in Islamic banks. The first comprehensive information on exposure to real estate risk for U.A.E. banks has become available at end-2010. This data comprises direct lending to individuals, corporate and developers for the purchase and construction of real estate, as well as indirect exposures (financial guarantees, loans to and shares in real estate investment companies). Exposure to real estate accounts for 38 percent of Islamic banks' lending; 29 percent for conventional banks (Figure II.13). Overall, U.A.E. banks would have the second highest exposure to real estate and construction in the GCC, after Kuwait (Figure II.14). The size of the property overhang in Dubai and the lack of transactions in less favorable locations imply that some of these exposures may have to be written down sharply. In some cases, this could happen over several years, as many loans to Dubai real estate-related GREs have been restructured to mature after 2014.

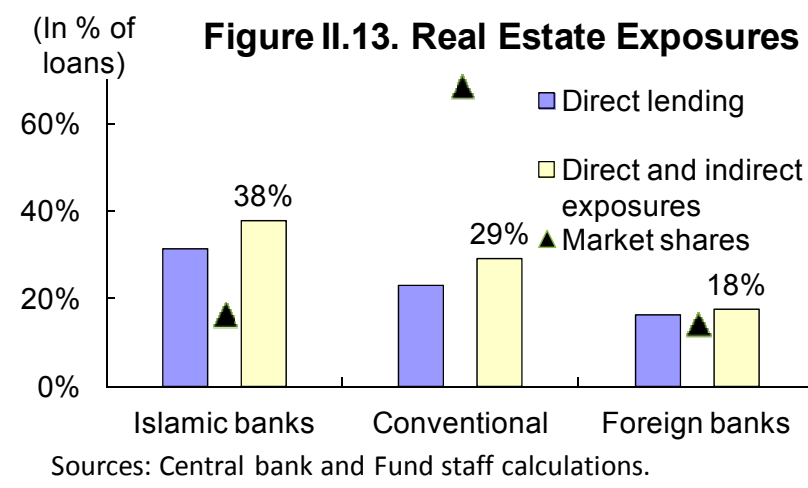

38. The CBU has issued new regulations to harmonize loan classification and provisioning practices across banks, and to move toward forward-looking provisioning. U.A.E. banks follow the International Financial Reporting Standard (IFRS) under which there are two categories of provisions: specific impairment; collective impairment (general

\footnotetext{
${ }^{10}$ Although auditors have advised banks to report DW loans as NPLs, reporting has been somewhat inconsistent, although the effects are disclosed in notes to financial statements. Banks that classified DW loans reported higher NPLs but lower provisioning ratios, because NPV losses have been low.
} 
provisions). ${ }^{11}$ Differences in banks' models and risk management protocols, as well as the relative importance of these categories in the mix of lending across banks, have made it difficult to compare the adequacy of such provisions under IFRS. To complement IFRS, the central bank issued in 2010 new loan classification and provisioning guidelines to help ensure greater uniformity across banks and increase the banks' forward looking general provisions (Box II.1). Preliminary indications from 2010 financial reports are that provisioning ratios have converged across local banks.

\section{Box II.1. Central Bank Regulations on Loan Classification and Provisioning}

Circular 28/2010 of November 11, 2010 can be summarized as follows:

- Corporate loans under banks' internal loan grading systems: a minimum of five loan buckets (normal; watch-list; substandard, doubtful, loss) and minimum provisioning for the bottom three categories $(25,50$, and 100 percent), as well as for accrued interest. Specific provisions must be booked in the quarter in which losses become quantifiable. In the past, some banks would wait to book provisions after discussions with auditors during the annual exercise. This implied that some provisions could "catch up" as late as four quarters after the fact;

- Guidelines on whether overdraft loans are considered performing;

- Consumer loans must be provisioned based on past due criteria (90, 120, 180 days);

- Greater uniformity in general provisions, which currently stand at 1.25 percent of riskweighted assets in the aggregate, but with significant variations across banks. New guidelines require each bank individually to have general provisions in excess of 1.5 percent by 2014 .

In a separate instruction, the CBU has increased its mandated provisioning on impaired Saudi corporate exposures from 50 percent at end- 2009 to 80 percent at end-2010.

\section{Outlook and Risks}

39. Local banks seem able to withstand further provisioning requirements in the short term from their core earnings. Classified loans have almost doubled since the crisis, the second highest increase in the GCC after Kuwait (Table II.1). Net interest margins have remained resilient so far, and have been sufficient to cover the associated provisions. As a result, banks have remained profitable in the aggregate both in 2009 and 2010 . The capital adequacy ratio has increased from the lowest in the GCC (13 percent in December 2008) to the highest (20.8 percent), mostly because of government support. ${ }^{12}$

\footnotetext{
${ }^{11}$ Specific provisions apply to loans that are monitored individually because they are materially significant; provisioning occurs when the loan is impaired and the loss is quantifiable. General provisions pertain to two types of exposures: (i) individually significant exposures for which loss is likely but cannot yet be quantified - this would have been the case for DW before terms were known; (ii) small loans of similar characteristics such as residential mortgage cohorts, credit card or car loans, where banks use models to calculate provisions.

${ }^{12}$ The regulatory minimum capital is 12 percent since June 2011, of which 8 percent must be tier 1 .
} 
Table II.1. GCC: Selected Financial Soundness Indicators 1/

(In percent)

\begin{tabular}{|c|c|c|c|c|c|c|c|c|c|c|}
\hline & \multicolumn{2}{|c|}{$\begin{array}{c}\text { Nonperforming } \\
\text { Loans }\end{array}$} & \multicolumn{2}{|c|}{$\begin{array}{c}\text { Capital } \\
\text { Adequacy }\end{array}$} & \multicolumn{2}{|c|}{$\begin{array}{l}\text { Provisioning } \\
\text { Rate }\end{array}$} & \multicolumn{2}{|c|}{$\begin{array}{c}\text { Return on } \\
\text { Assets }\end{array}$} & \multicolumn{2}{|c|}{$\begin{array}{l}\text { Return on } \\
\text { Equity }\end{array}$} \\
\hline & 2007 & Latest & 2007 & Latest & 2007 & Latest & 2007 & Latest & 2007 & Latest \\
\hline Bahrain & 2.3 & 3.9 & 21.0 & 19.6 & 74.0 & 60.3 & 1.2 & 1.2 & 18.4 & 10.6 \\
\hline Kuwait & 3.2 & 9.7 & 19.4 & 18.0 & 48.2 & 38.5 & 3.6 & 0.8 & 29.4 & 6.9 \\
\hline Oman & 3.2 & 3.5 & 15.8 & 15.5 & 111.8 & 104.0 & 2.1 & 1.4 & 14.3 & 10.0 \\
\hline Qatar & 1.5 & 1.7 & 13.5 & 16.1 & 90.7 & 84.5 & 3.6 & 2.6 & 30.4 & 19.3 \\
\hline Saudi Arabia & 2.1 & 3.3 & 20.6 & 16.5 & 142.9 & 89.8 & 2.8 & 2.0 & 28.5 & 25.8 \\
\hline U.A.E. 2/ & 2.9 & 5.9 & 14.0 & 20.8 & 100.0 & 88.6 & 2.0 & 1.4 & 19.3 & 8.4 \\
\hline
\end{tabular}

Source: Country authorities.

1/ End-2009, unless otherwise indicated

2/ Local banks, December 2010. Assuming half of 2010 profits retained. Provisions are collective and specific under IFRS.

\section{High capital and earnings for the aggregate banking system mask the greater}

pressure on Dubai-based banks (Table II.2). Dubai banks have NPLs almost twice as high as Abu Dhabi banks. The associated provisioning has dampened their profitability to half the level of Abu Dhabi banks. Efforts of Dubai banks to improve their liquidity profile, including by shrinking lending, have also weighed on profits. Provisioning ratios are identical across local banks; they are lower in foreign banks, reflecting possibly the reporting of DW loans.

\begin{tabular}{|c|c|c|c|c|c|}
\hline (in percent) & Dubai banks & Abu Dhabi banks & Other local banks & All local banks & Foreign banks \\
\hline \multicolumn{6}{|l|}{ Capital } \\
\hline Regulatory capital ratio $1 /$ & 20.2 & 20.3 & 28.0 & 20.8 & 16.5 \\
\hline Tier 1 ratio & 14.3 & 16.1 & 25.2 & 16.9 & 13.6 \\
\hline Risk-weighted assets/total assets & $75 \%$ & $81 \%$ & $78 \%$ & $78 \%$ & $72 \%$ \\
\hline \multicolumn{6}{|l|}{ Asset quality } \\
\hline Classified credit/total credit & 8.0 & 4.4 & 4.3 & 5.9 & 9.7 \\
\hline Provisions/classified credit & 87 & 89 & 98 & 89 & 68 \\
\hline \multicolumn{6}{|l|}{ Selected exposures (percent of loans) } \\
\hline Real estate (direct) $1 /$ & 23 & 25 & 17 & 23 & 17 \\
\hline Dubai GREs & 16 & 4 & 2 & .. &.. \\
\hline \multicolumn{6}{|l|}{ Liquidity/funding } \\
\hline Stable funding ratio per regulation & 88 & 91 & 85 & 87 & 77 \\
\hline Loan/deposit ratio & 97 & 108 & 101 & 103 & 84 \\
\hline Government deposits (\% of deposits) & 15 & 30 & .. & .. & .. \\
\hline \multicolumn{6}{|l|}{ Earnings } \\
\hline ROA & 0.8 & 1.6 & 2.7 & 1.4 & 1.5 \\
\hline ROE & 4.9 & 9.8 & 12.6 & 8.4 & 12.7 \\
\hline Leverage (equity/assets) & $16.3 \%$ & $16.3 \%$ & $21.4 \%$ & $16.7 \%$ & $11.8 \%$ \\
\hline \multicolumn{6}{|l|}{ Memo items } \\
\hline Loan market shares & $33 \%$ & $44 \%$ & $6 \%$ & $84 \%$ & $16 \%$ \\
\hline Deposit market shares & $34 \%$ & $41 \%$ & $6 \%$ & $81 \%$ & $19 \%$ \\
\hline Credit growth (Sep 2009/Sep 2010) & $-5.4 \%$ & $8.6 \%$ & $9.0 \%$ & $2.5 \%$ & $0.8 \%$ \\
\hline Deposit growth (Sep 2009/Sep 2010) & $-4.0 \%$ & $9.0 \%$ & $12.2 \%$ & $3.3 \%$ & $5.4 \%$ \\
\hline
\end{tabular}

Sources: Central Bank and Fund staff estimates and calculations

1/ Assuming half of 2010 profits retained.

41. Over the medium term, some banks may need to make up for the decline in capital support by the federal government. Federal government support in the form of capital notes qualifies as tier 2 capital until 2012. Thereafter, the notes amortize at the rate of 20 percent per year until maturity in 2017. The rate of amortization implies that banks' capital adequacy will 
decline by 1 percentage point per year between 2013 and 2017, which, all else equal, would reduce the current CAR from 21 percent to 16 percent. Banks could counter this erosion through retained earnings in order to replace the maturing notes with tier 1 equity. The relatively high interest rate of the capital notes provides strong banks with an incentive to exit government support: they have the option to pay back starting in 2014.

\section{Banks also need to prepare for a potential new bout of stress when restructured} loans mature in a few years. Real estate related loans are being restructured with longer maturities in Dubai on the premise that prices will have recovered in a few years. If wrong, there is a risk that these borrowers (GREs and private entities) will not be able to repay their loans when these start to mature after 2014. Thus, the potential scramble to sell property at that time to repay the loans, which coincides with the progressive decline of government capital support, could mean a further bout of pressure on banks.

\section{Credit risk}

43. Credit risk remains the dominant risk, a function of falling property prices and the associated impact on growth and employment. Real estate prices in Dubai have stabilized somewhat over the past year although less desirable locations have had continued price drops. Property brokers expect some further price deterioration before buyers come in, more on the commercial than on the residential side.

44. The experience of banking stress in markets with acute property bubbles has been used to gauge the potential for further loan deterioration. In these markets, NPLs currently range from 6 percent (Spain) to 10-11 percent (Florida, Ireland). Most of these markets have experienced more severe recessions than Dubai, as well as weaker growth prospects in 2011. In the U.S. markets, loan deterioration has peaked as a result of economic recovery. While Dubai's economy has entered a recovery phase, its property prices are still expected to fall, which could result in higher NPLs going forward.

\section{A severe stress scenario could boost NPLs to 15 percent, which would be higher} than currently in Ireland. A less severe scenario would push NPLs to 10 percent, or above current levels in Spain or U.S. states. (Figure II.15). At end-2010, NPL stood at 5.9 percent for the system as a whole and 8 percent for Dubai banks, up from less than 3 percent before the crisis in both cases. Under the scenarios, banks maintain the provisioning ratio at 90 percent (IFRS general and specific); provisions would need to be constituted in 2011; 2010 profits are 50 percent retained; and 2011 pre-provision earnings are half the levels of 2009-10 from a combination of higher funding costs and lower lending rates. The scenario subsumes further write-offs in the value of investments, which represent about 10 percent of bank assets. The test is conducted on the aggregate balance sheet of local banks and, separately, on the aggregate balance sheet of Dubai banks. 
Figure II.15 NPL Paths in Selected Banking Markets with Acute Property Bubbles
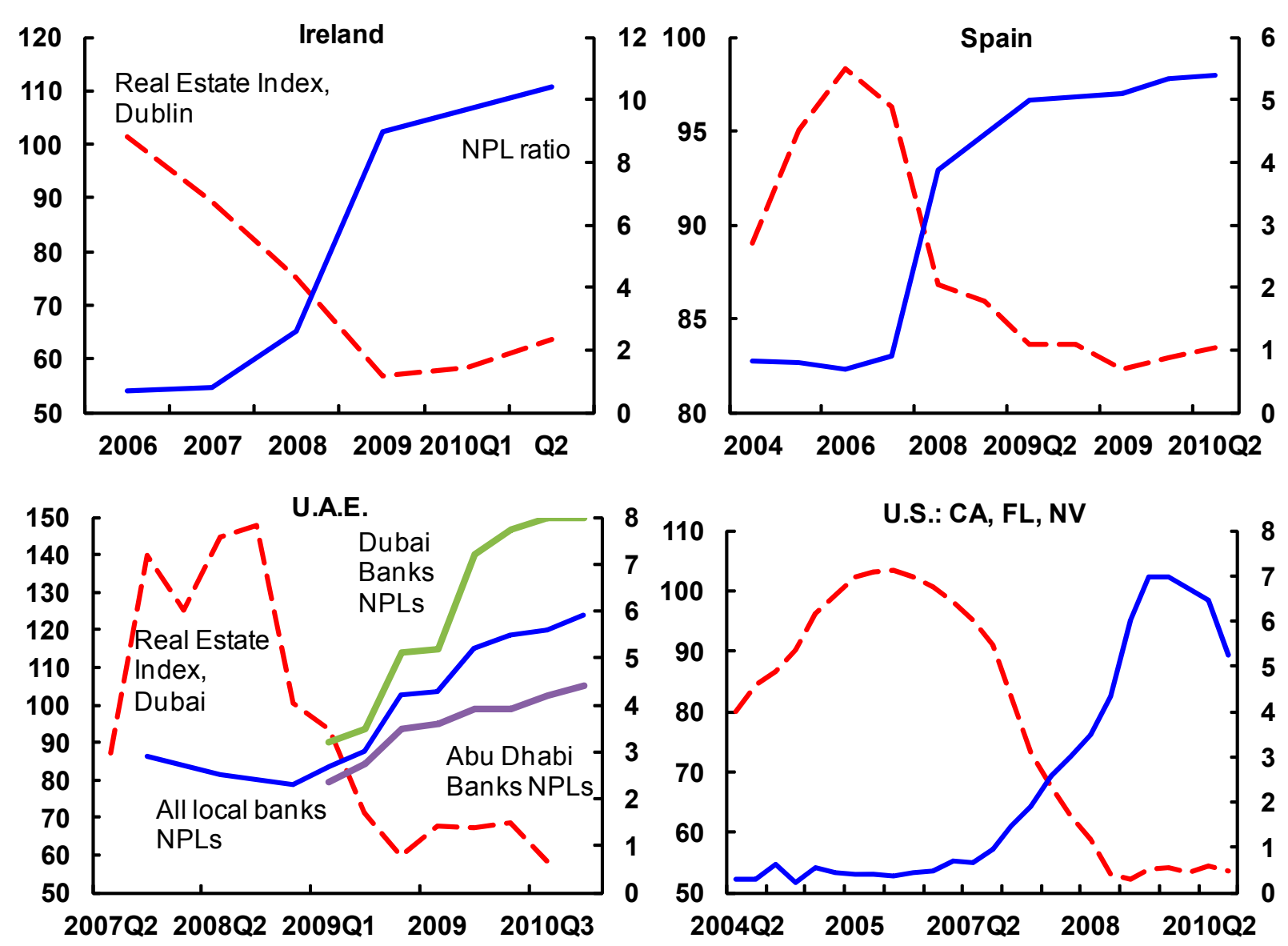

Sources: Haver; Case/Shiller (San Francisco, Los Angeles, San Diego, Miami, Tampa, Las Vegas); Dubai Land Dep.; Bank of Spain; Bankscope; GFSR; CBU.

46. The severe scenario on end-2010 data suggests that the system could withstand the stress. System CAR would fall to 14.8 percent under the severe scenario, and 10.9 percent for the tier 1 ratio (Table II.3). Banks are required to be above 12 percent and 8 percent respectively. Aggregate system capital would fall below levels of peers in the GCC assuming these other banking systems are immune from stress. 
Table II.3. U.A.E.: Stress Test for Aggregate Local Banks

\begin{tabular}{lccl} 
& Regulatory capital & Tier 1 capital & Comments \\
\hline 2009 CAR & $19.9 \%$ & $16.0 \%$ & tier 2 capital provided by government \\
2010 pre-provision earnings & 32,000 & 32000 & \\
2010 profits (AED millions) & 18,000 & 18,000 & \\
2010 CAR & $20.8 \%$ & $16.9 \%$ & assuming 50\% profits retained 1/ \\
NPL ratio (end-2010) & $5.9 \%$ & $5.9 \%$ & \\
Provision rate (end-2010) & $89 \%$ & $89 \%$ & IFRS general and specific \\
Provisions if NPLs rise to 10\% in 2011 & 38,000 & 38,000 & assuming provision rate of $90 \%$ on new NPLs 2/ \\
2011 CAR with NPLs of 10\% & $18.7 \%$ & $14.8 \%$ & assuming 50\% lower pre-provision earnings \\
2011 CAR with NPLs of 15\% & $14.8 \%$ & $10.9 \%$ & \\
Memo items & & & \\
Min regulatory capital & $12 \%$ & $8 \%$ & \\
Total assets (AED billions) & 1,352 & 1,352 & \\
Risk-weighted assets (AED billions) & 1,055 & 1,055 & \\
\hline
\end{tabular}

Sources: Central bank and Fund staff estimates and calculations.

$1 /$ In line with central bank instructions to limit distribution of 2010 profits.

$2 /$ Including Dubai Holding provisions of $20 \%$ of original principal.

\section{The severe scenario shows somewhat greater pressure on Dubai banks, particularly} as concerns tier 1 capital levels. CAR for Dubai banks would fall to 15.3 percent under the severe scenario, and 9.4 percent for the tier 1 ratio (Table II.4). Although Dubai banks would still meet the regulatory minima in the aggregate, it is possible that individual banks would not. Indeed, the test on aggregate data ignores idiosyncratic risks that could exist in individual banks, for example, from large exposures to troubled borrowers or sectors. The greater pressure on Dubai banks comes mainly from lower levels of tier 1 capital. It is worth pointing out that tier 2 capital is provided by the federal government, and could be readily converted into tier 1 . In case of such interventions, the share of government ownership would increase further, with the novelty that the federal government would now also have a direct stake.

Table II.4. U.A.E.: Stress Test for Aggregate Dubai Banks

\begin{tabular}{|c|c|c|c|}
\hline & Regulatory capital & Tier 1 capital & Comments \\
\hline 2009 CAR & $19.7 \%$ & $13.8 \%$ & tier 2 capital provided by government \\
\hline 2010 pre-provision earnings & 11,000 & 11,000 & \\
\hline 2010 profits (AED millions) & 4,500 & 4,500 & \\
\hline 2010 CAR & $20.2 \%$ & $14.3 \%$ & assuming $50 \%$ profits retained $1 /$ \\
\hline NPL ratio (end-2010) & $8.0 \%$ & $8.0 \%$ & \\
\hline Provision rate (end-2010) & $87 \%$ & $87 \%$ & IFRS general and specific \\
\hline Provisions if NPLs rise to $10 \%$ in 2011 & 10,000 & 10,000 & assuming provision rate of $90 \%$ on new NPLs $2 / 3 /$ \\
\hline 2011 CAR with NPLs of $10 \%$ & $19.2 \%$ & $13.3 \%$ & assuming $50 \%$ lower pre-provision earnings \\
\hline 2011 CAR with NPLs of $15 \%$ & $15.3 \%$ & $9.4 \%$ & \\
\hline \multicolumn{4}{|l|}{ Memo items } \\
\hline Min regulatory capital & $12 \%$ & $8 \%$ & \\
\hline Total assets (AED billions) & 550 & 550 & \\
\hline Risk-weighted assets (AED billions) & 411 & 411 & \\
\hline
\end{tabular}




\section{Liquidity risk}

48. The banking system would meet 69 percent of the Basel III requirement, compared to 98 percent under the Basel Committee impact study of comparable banks in the Committee's member countries. This assessment was done by the central bank on September 2010 data, using the Basel standard that will come into effect in $2015 .^{13}$ To meet the required 100 percent by 2015 , the system would need to hold an extra stock of high quality assets worth about 11 percent of GDP (Figure II.16). ${ }^{14}$ The central bank's impact study suggests that the opportunity cost of holding Figure II.16. Liquidity Coverage

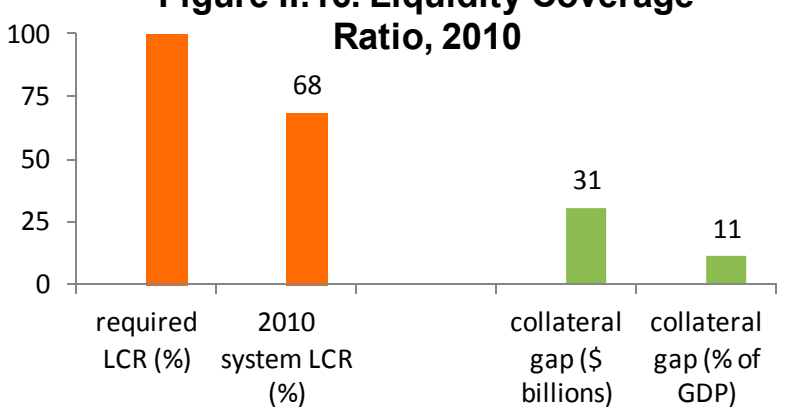

Sources: Central bank and Fund staff calculations. more high quality assets could lower aggregate bank earnings by about 20 percent.

49. The Dubai banks have less liquidity deficit than the Abu Dhabi banks. When measured by size of assets, the large Abu Dhabi banks have liquidity coverage ratios below 50 percent (Figure II.17). Their large ownership by the Abu Dhabi government allows them to operate with lower liquidity buffers. This reflects the financial wealth of the Abu Dhabi government.

Figure II.17. Distribution of Liquidity Coverage Ratios

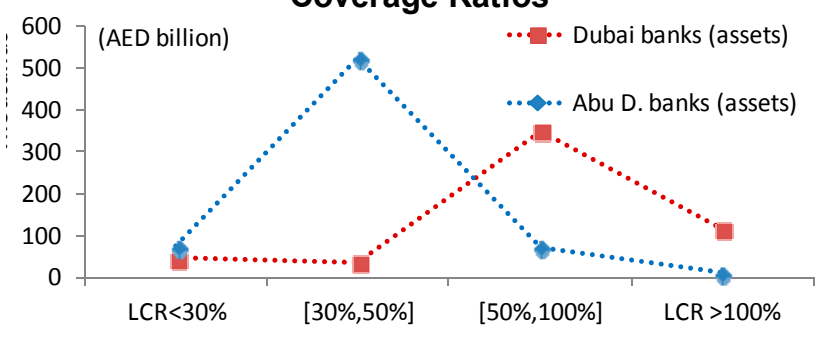

Sources: Central bank and Fund staff calculations.

\section{To help meet the Basel standard by 2015, the authorities are considering issuing} federal government securities for the first time. The authorities are about to promulgate a public debt law that would allow the federal government to issue local debt. The securities would be held on banks' balance sheet, hence would have limited liquidity. However, they would be eligible collateral for central bank liquidity in case of stress, as well as being collateral for secured term funding abroad and interbank repos. The issuance of federal government securities would however be hampered by the small revenue base of the federal government and

\footnotetext{
${ }^{13}$ The Basel III liquidity coverage ratio penalizes U.A.E. banks on two counts: (i) on the asset side, the lack of high quality collateral in the form of local government debt; (ii) a funding structure that features price-sensitive corporate deposits rather than stickier retail deposits (households and SMEs), which under the liquidity test, have differentiated drain rates.

${ }^{14}$ One-third of the banks met the liquidity coverage ratio requirement in September 2010.
} 
the low overall ceiling in the law. Accordingly, the potential additional volume appears limited. The need for high quality assets would be lower to the extent banks increase the proportion of retail deposits (considered more stable) or foreign term funding in their liability mix. However, the development of retail deposits is constrained by an economic model that relies on large-scale expatriate labor and remittances.

\section{E. Policies for Financial Stability}

51. There is merit in conducting an in-depth diagnostic of bank governance. The prevalence of government control of local banks, as well as concentration risk in some banks, highlights the potential for governance issues. Good governance complements effective supervision and is integral to the implementation of the risk-based approach to oversight. The diagnostic would evaluate specific aspects of the legal and regulatory framework and the way in which the supervisor emphasizes governance. The approach is based on the 2006 guidelines of the Basel Committee, "Enhancing Corporate Governance for Banking Organizations," and is conducted by the World Bank.

\section{Recent central bank measures to harmonize provisioning practices across banks} will help strengthen confidence. The 2010 CBU circulars on provisioning and loan classification will improve banks' financial strength by ensuring harmonization of practices across banks. The CBU could also require banks to report the restructured part of their loan book by sector and monitor the maturity profiles of such loans, with particular attention to bunching. On-site inspections should examine the classification and provisioning of loans that become serially restructured. In case of significant divergence of practices across banks, the CBU could consider minimum standards for the classification and provisioning of such loans. With the more comprehensive data on real estate exposure now available, the CBU should also monitor closely the risk management practices of banks with large exposure to real estate risk.

\section{The central bank could contain dividend distribution over the next few years to ensure that the banks are ready for an eventual roll-over risk without new government} support. To this end, the CBU could run stress tests with a uniform set of parameters across the industry and link the approval of dividend distribution to the results of these tests. A push to retain earnings and provision in line with risks will provide a strong signal of confidence to depositors and investors, while preparing banks to absorb the potential release of losses should risks related to restructured loans materialize in a few years.

\section{The CBU could consider additional measures to prepare for the Basel III liquidity} standard that would come into effect in 2015. Given the limited role that federal debt can play in improving bank liquidity, the authorities could explore the possibility of a greater role for term funding from non-traditional sources, such as government sources. 


\section{Fiscal Policy and Fiscal CoOrdination in the United Arab Emirates: DraWing LesSONS From THE CRISIS ${ }^{15}$}

\section{A. Introduction}

55. Procyclical fiscal policies and the build-up of contingent liabilities during the boom years exacerbated the severity of the crisis. ${ }^{16}$ Since the U.A.E. has a pegged exchange rate and consequently a limited capacity to use monetary policy, the onus of macroeconomic stabilization falls on fiscal policy. The excessive fiscal stimulus prior to the crisis, however, exacerbated the economic cycle and contributed to the build-up of vulnerabilities. With the global financial crisis, the unraveling of Dubai's growth model has also raised concerns over the sustainability of public finances, especially in light of the risks stemming from governmentrelated entities (GREs). In addition to the contingent liabilities that contaminated the sovereign balance sheet, the crisis revealed the predicament of implicit government guarantees - a manifestation of moral hazard in a federal system with an asymmetric distribution of resources.

56. This paper analyses fiscal policy in the run-up and after the crisis and suggests a set of measures to strengthen fiscal policy management in the U.A.E. As the crisis is partly a materialization of heterogeneous and diverging sub-national fiscal capabilities, Section B describes the main institutional features of fiscal federalism in the U.A.E. Section $C$ presents estimates of the cyclically-adjusted nonhydrocarbon primary budget balance before and after the crisis at the consolidated and sub-national level. Section D contains an analysis of fiscal sustainability in the U.A.E. as a whole and in the Emirate of Dubai. Finally, Section E sets out policy lessons to develop a set of rules to anchor fiscal policy and to improve coordination between the various levels of government.

\section{B. Fiscal Federalism in the U.A.E.}

57. The U.A.E. is a confederation of emirates, with each maintaining full autonomy over hydrocarbon resources and fiscal policies. In 1971, the seven emirates-Abu Dhabi, Ajman, Dubai, Fujairah, Ras al-Khaimah, Sharjah and Umn al-Qaiwain - formed the U.A.E. with a provisional constitution. Each emirate can exercise power in all matters that are not assigned to the jurisdiction of the federal government, and the natural resources and wealth in each emirate are the public property of that emirate. As a result, while monetary and exchange rate policy is managed on a federal basis by the Central Bank of the U.A.E., each emirate manages its own budget on an independent basis and no emirate has an obligation to contribute to the budget of any other emirate.

\footnotetext{
${ }^{15}$ Prepared by Serhan Cevik.

${ }^{16}$ After a decade-long above-trend expansion at an annual real GDP growth rate of 7 percent between 1999 and 2008, the U.A.E. economy is estimated to have contracted by 2.6 percent in 2009 as lower hydrocarbon prices and the shutdown of international capital markets led to a sharp correction in real estate prices.
} 


\section{The U.A.E. federal government lacks an independent fiscal base and remains} dependent on transfers from Abu Dhabi and Dubai. The largest and wealthiest emirates of Abu Dhabi and Dubai make contributions to the federal budget in agreed amounts, and Abu Dhabi also separately contributes to fund security and defense, which are federal responsibilities but managed by Abu Dhabi. The federal government has a limited revenue base, with its budget amounting to about 4 percent of GDP and 10 percent of total public expenditure in the U.A.E.

\section{Cyclicality of Fiscal Policy Before and After the Crisis}

59. The cyclically-adjusted nonhydrocarbon primary balance is the appropriate measure of the fiscal stance in a hydrocarbon-based economy. The overall and primary fiscal balances are widely used indicators to assess the government's net financing requirement - or accumulation of net financial assets - and its fiscal vulnerability. Because of the volatility of oil prices, however, it can give a misleading picture of the underlying fiscal stance and possible structural imbalances in a hydrocarbon-based economy (Figure III.1). The nonhydrocarbon primary balance, factoring out resource-based revenue, including investment income of the sovereign wealth fund, provide a better indication of the fiscal stance ${ }^{17}$ Furthermore, since the actual balance reflects cyclical or temporary effects on the budget, as well as structural or permanent influences, it is important to refine the measurement of the fiscal stance further by constructing a cyclically-adjusted nonhydrocarbon primary balance, which reflects government revenues and expenditures adjusted for the impact of the economic cycle.

Figure III.1. The U.A.E.: Oil Price and Budget Balances, 1990-2010
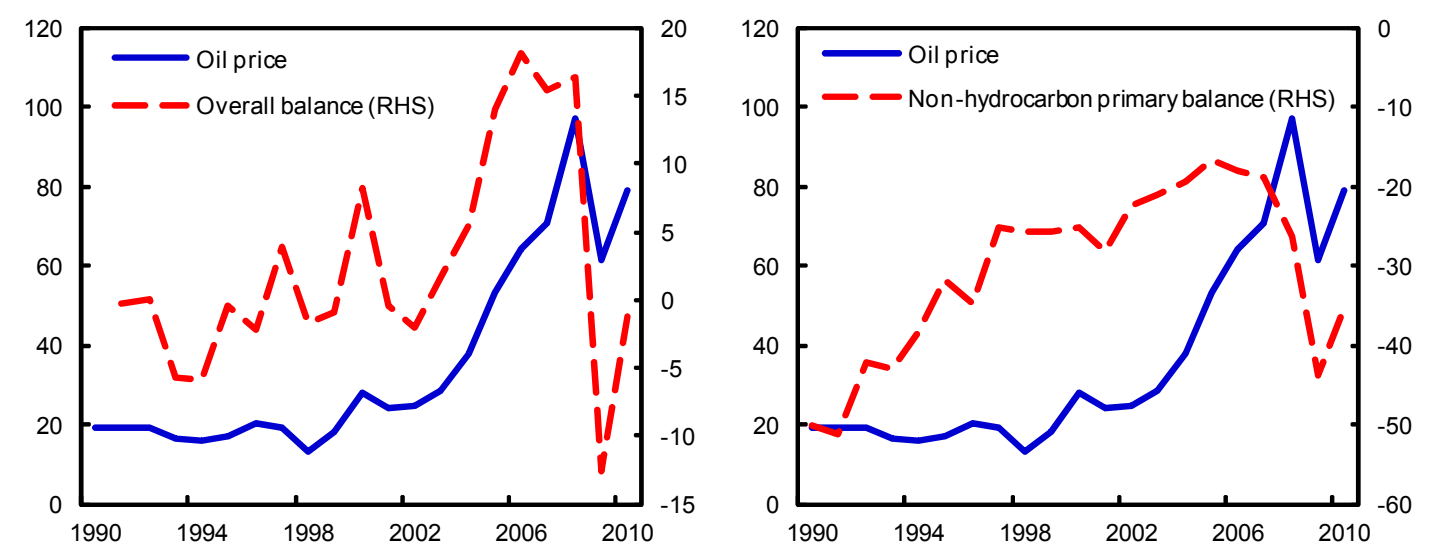

Source: Author's calculations.

\footnotetext{
${ }^{17}$ Investment income is usually reinvested abroad and therefore does not influence domestic aggregate demand.
} 
60. Fiscal policy is expansionary (contractionary) when the change in the cyclicallyadjusted nonhydrocarbon primary balance is negative (positive). After separating the change in the nonhydrocarbon primary balance into the change in the cyclical nonhydrocarbon primary balance and the change in the cyclically-adjusted nonhydrocarbon primary balance, we can define fiscal policy as expansionary (contractionary) when the change in cyclicallyadjusted nonhydrocarbon primary balance is negative (positive). To assess whether fiscal policy is countercyclical (procyclical), we have to examine the link between changes in the output gap and the change in the cyclically-adjusted primary balance. Expansionary (contractionary) fiscal policy when the change in the output gap is positive (negative) would be procyclical, exacerbating pressures in the economy, while expansionary (contractionary) policy when the change in the output gap is negative (positive) is countercyclical, dampening cyclical fluctuations in the economy.

\section{Estimates of potential output are subject to uncertainty in an economy like the} U.A.E. with a perfectly elastic labor supply. The U.A.E. economy moved from below potential growth during 1998-2004 to above potential growth in 2005-08. The boom period, starting in 2003, led to a swing of more than 19 percentage points in the output gap from -11.8 percent of nonhydrocarbon GDP in 2002 to 7.3 percent in 2008. However, output gap estimates are subject to uncertainty, especially with a short time series and in an economy with a highly elastic labor supply (Figure III.2). When expatriate workers account for about 90 percent of the workforce, the concept of the "natural rate of unemployment" is not informative as to whether the economy is operating below or above its potential. Furthermore, the estimated increase in potential GDP during the boom years may have been partly a result of the easy availability of credit and the real estate bubble, and consequently not as sustainable as a productivity-driven improvement. Nevertheless, despite the empirical shortcomings, estimates of potential GDP and output gap are consistent with inflation trends before, during and after the crisis, and therefore present a reasonable gauge of deviation from trend growth.

Figure III.2. The U.A.E.: Output Gap, Inflation and Expatriate Workers
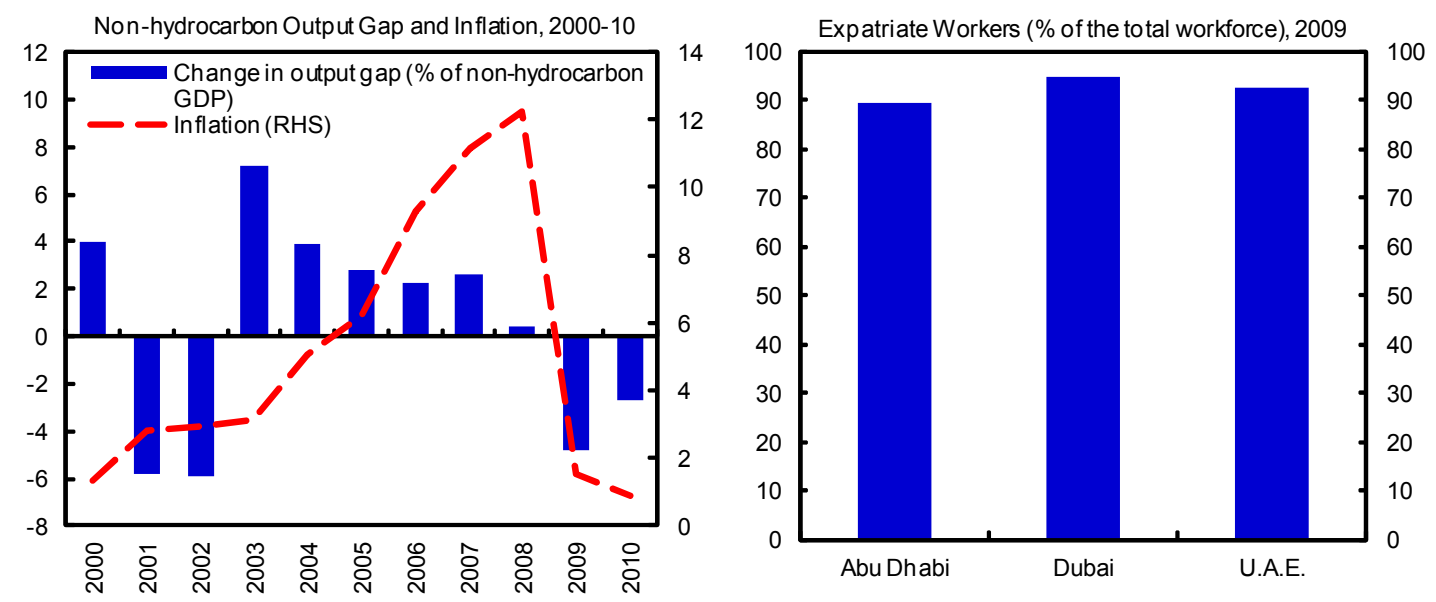

Sources: National Bureau of Statistics, Ministry of Labor, author's calculations. 
62. The U.A.E.'s consolidated fiscal stance has been expansionary before and after the crisis, irrespective of measurement techniques. The nonhydrocarbon primary budget deficit, excluding investment income, widened from 16.5 percent of nonhydrocarbon GDP in 2005 to 26.3 percent in 2008 , while the cyclically-adjusted nonhydrocarbon primary deficit increased from 17 percent to 28.8 percent. As a result, the fiscal impulse - measured by the change in the cyclically-adjusted nonhydrocarbon primary balance as a share of nonhydrocarbon potential GDP - amounted to 11.8 percentage points on a cumulative basis over this period (Figure III.3). Facing a steep economic downturn, the authorities responded with countercyclical measures, pushing the cyclically-adjusted nonhydrocarbon primary deficit to 45.2 percent of nonhydrocarbon GDP in 2009.

63. Comparing the change in the cyclically-adjusted nonhydrocarbon primary balance and the output gap shows the cyclicality of fiscal policy. The combination of positive changes in the output gap with positive fiscal impulse implies a procyclical fiscal policy stance. Using this methodology, we find that fiscal policy was procyclical prior to the crisis when the U.A.E. economy experienced an unprecedented above-potential boom and sustained inflationary pressures. After the crisis, facing a negative output gap, the authorities adopted a countercyclical stance and raised the cyclically-adjusted nonhydrocarbon primary budget deficit to 45.2 percent of nonhydrocarbon GDP in 2009. However, in 2010, the fiscal policy stance turned contractionary and procyclical, with the cyclically-adjusted nonhydrocarbon primary deficit narrowing to 35.1 percent of nonhydrocarbon GDP.

Figure III.3. The U.A.E.: Fiscal Policy Stance, 2000-10
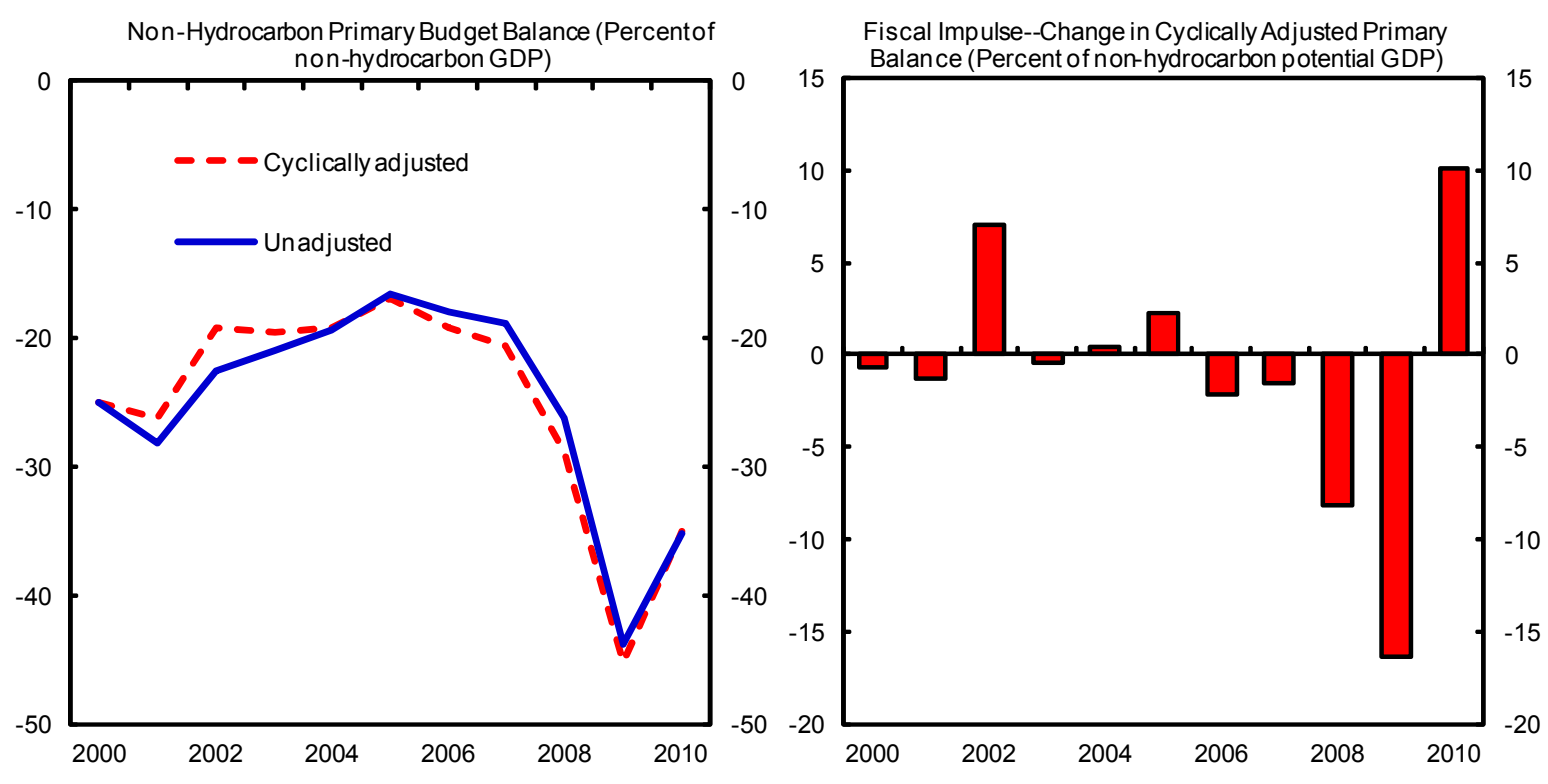

Source: Author's calculations. 


\section{Both Abu Dhabi and Dubai adopted procyclical fiscal policies prior to the crisis.}

- $\quad$ Abu Dhabi, accounting for almost 70 percent of government revenues, dominates the U.A.E.'s consolidated fiscal position. Abu Dhabi is the largest and most wealthy emirate, controlling more than 95 percent of the country's hydrocarbon reserves, and therefore enjoys abundant fiscal space relative to other emirates. The nonhydrocarbon primary budget deficit widened by 19.2 percentage points of Abu Dhabi nonhydrocarbon GDP in 2006-08; and the cyclically-adjusted nonhydrocarbon primary budget deficit, excluding investment income, also shows a fiscal impulse of 21.7 percentage points of Abu Dhabi nonhydrocarbon potential GDP during the same period (Figure III.4).

- $\quad$ Dubai has a relatively more diversified economy with nonhydrocarbon sectors representing over 95 percent of GDP. Nevertheless, the development of its revenue mobilization capabilities have not developed rapidly when compared to other diversified emerging market economies. Similar to Abu Dhabi, the cyclically-adjusted nonhydrocarbon primary deficit widened by 4 percentage points of Dubai and northern emirates GDP on a cumulative basis during 2004-08. However, these figures may significantly underestimate the extent of expansionary fiscal operations in Dubai where GRE investments were substantial (Figure III.5).

Figure III.4. Abu Dhabi: Fiscal Policy Stance, 2000-10
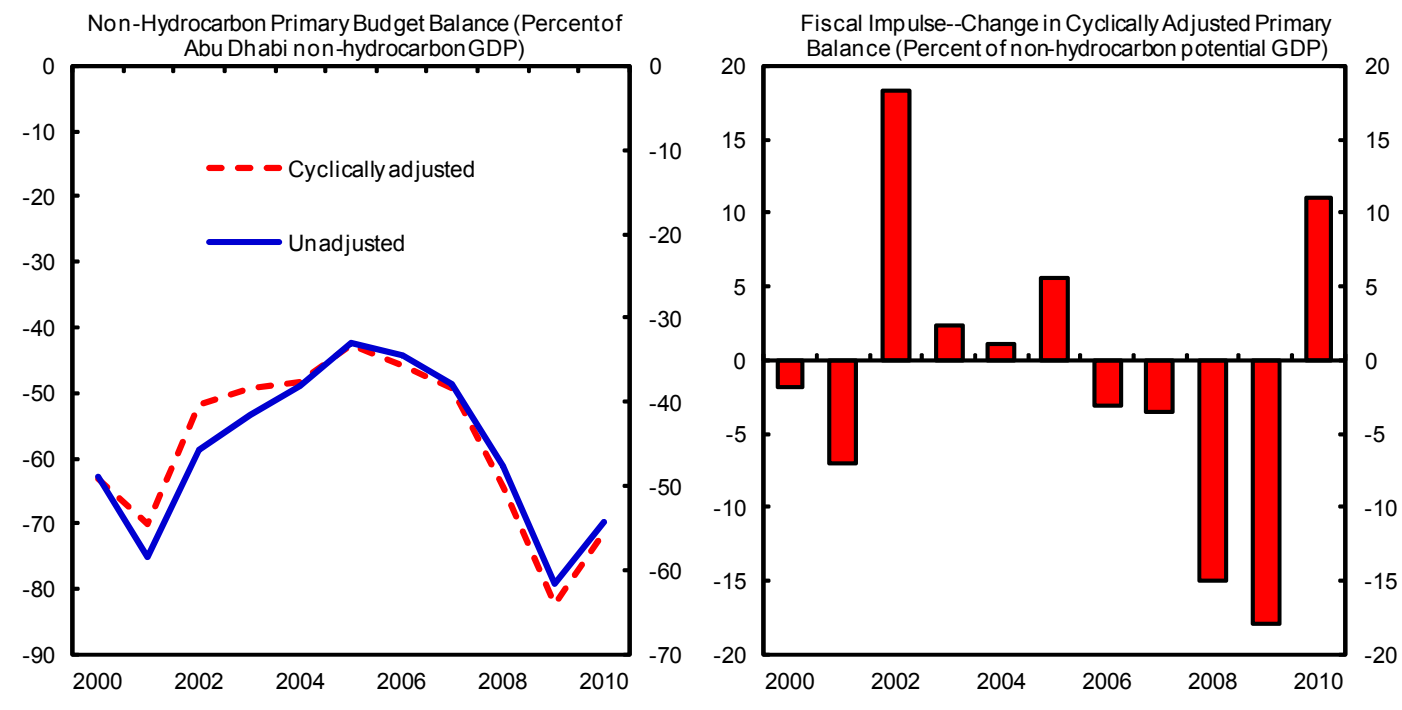

Source: Author's calculations. 
Figure III.5. Dubai: Fiscal Policy Stance, 2000-10
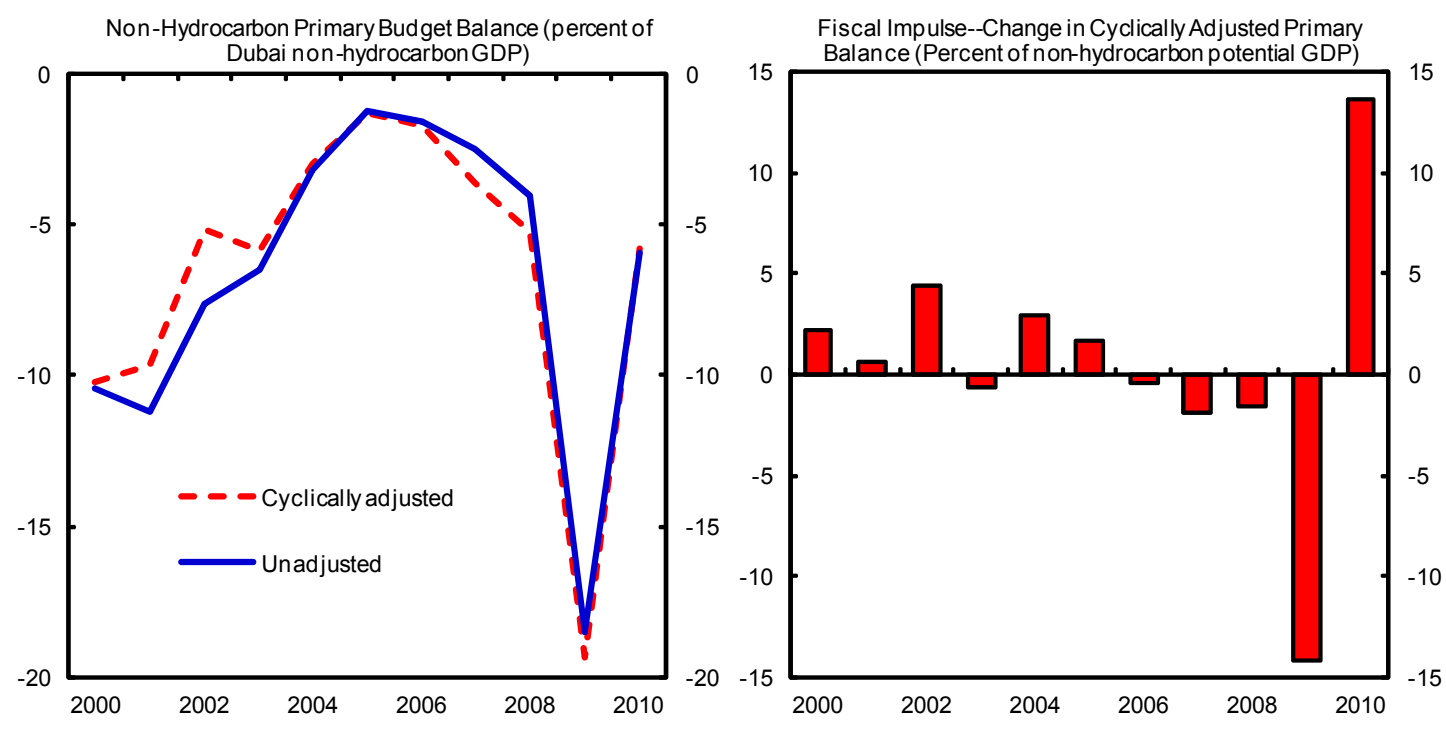

Source: Author's calculations.

65. Following the crisis, both Abu Dhabi and Dubai adopted countercyclical policies in 2009 and returned to the procyclical stance in 2010.

- In the wake of the global shock, the government of Abu Dhabi introduced a fiscal impulse of 18 percentage points of Abu Dhabi nonhydrocarbon potential GDP, which consequently led the cyclically-adjusted nonhydrocarbon primary deficit to an estimated 82.3 percent of Abu Dhabi nonhydrocarbon GDP in 2009. Moreover, these figures may not reflect the true extent of expansionary fiscal operations, given the significant role of GREs in the economy. The high share of GREs in Abu Dhabi's total public sector debt_-about 70 percent - implies that the fiscal impulse would be even greater if GRE spending were accounted for. In 2010, however, Abu Dhabi's fiscal policy stance turned contractionary and procyclical, with the cyclically-adjusted nonhydrocarbon primary deficit narrowing by more than 11 percentage points to 71.2 percent of Abu Dhabi's nonhydrocarbon GDP.

- Dubai's cyclically-adjusted nonhydrocarbon primary deficit widened to 14.1 percent of Dubai and northern emirates GDP in 2009. Although Dubai's fiscal stance turned countercyclical after the crisis, the shift was made possible by the financial support from Abu Dhabi and the Central Bank of the U.A.E., which accounted for 45 percent of government spending - and 9.6 percent of Dubai and northern emirates nonhydrocarbon GDP - in 2009. Accordingly, Dubai's fiscal policy stance became contractionary in 2010, with the cyclically-adjusted nonhydrocarbon primary deficit narrowing by 13.6 percentage points to 5.8 percent of Dubai and northern emirates GDP. 


\section{Fiscal Sustainability}

66. Fiscal sustainability has moved to center stage in light of the post-crisis contamination of the sovereign balance sheet by the materialization of contingent

liabilities. Gross government debt, excluding bank bilateral loans, rose from 3.6 percent of GDP in 2007 to 6.6 percent in 2008 and 15.8 percent in 2010 . Though debt sustainability is not an immediate issue for the U.A.E. as a whole, there are considerable differences at sub-national level. For example, Abu Dhabi, with its substantial hydrocarbon reserves and accumulated financial wealth, does not have a medium-term sustainability problem, whereas the built-up of contingent liabilities during the boom years has made Dubai more vulnerable.

67. The U.A.E. is estimated to have a nonhydrocarbon primary deficit more than the equilibrium level. The fiscal sustainability analysis based on permanent income hypothesis suggests that government spending at the consolidated level should be reduced over the medium term to ensure long-term sustainability and intergenerational equity (Figure III.6). Assuming constant real per capita government spending that delivers a constant per capita annuity after the depletion of hydrocarbon resources, the nonhydrocarbon primary deficit is estimated to be 4 percentage points higher than its equilibrium value in 2011, with the gap staying virtually unchanged at 3.9 percentage points by end-2016.

Figure III 6. The U.A.E.: Fiscal Sustainability Analysis, 2010-16

(Percent of non-hydrocarbon GDP)

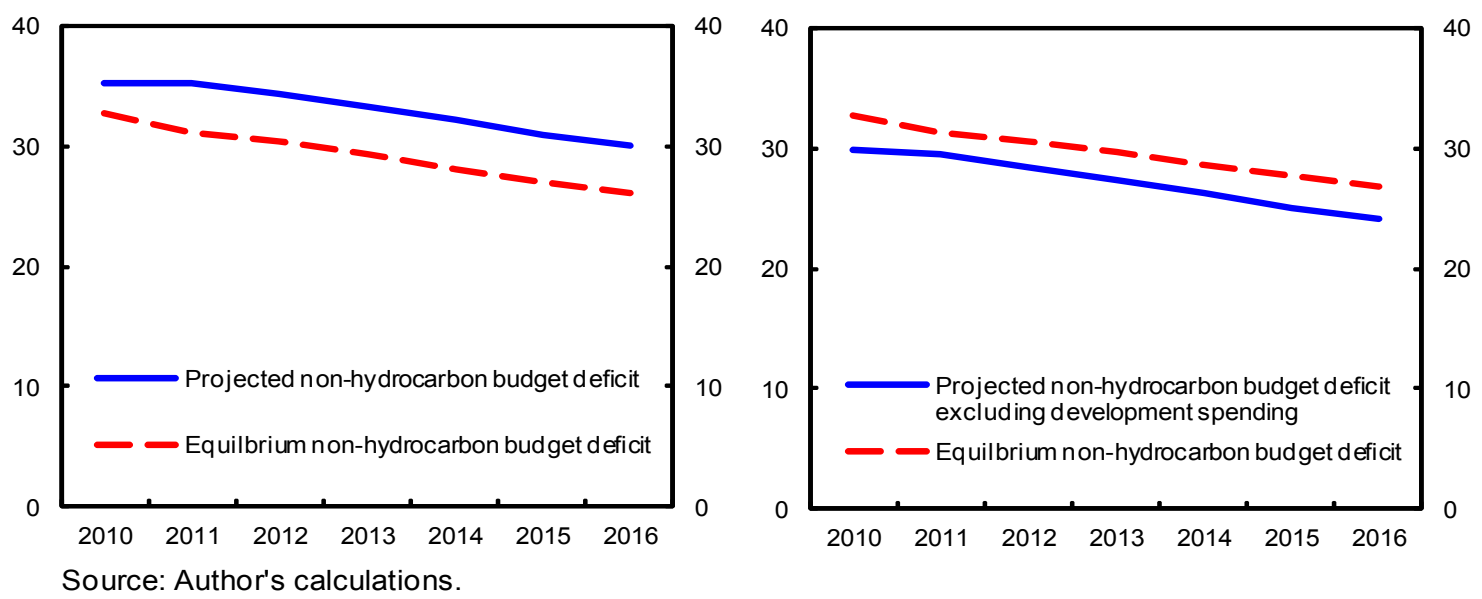

68. Alternative assumptions yield more favorable assessment of fiscal sustainability, but the results still indicate a need for fiscal prudence. Excluding development spending that may yield a return on investment equal to the discount rate used in the annuity calculation, the nonhydrocarbon primary deficit is estimated to be 2.9 percentage points below its equilibrium value in 2011 and remaining at 2.8 percentage points below the estimated 
equilibrium threshold by 2016 . While the results are sensitive to the parameter assumptions, they indicate a need for fiscal prudence from an intergenerational perspective. ${ }^{18}$

\section{Contingent liabilities stemming from underperforming GREs have raised Dubai's}

total public sector debt ratio. While the U.A.E. as a whole does not appear to have a sustainability problem over the medium term, the built-up of contingent liabilities leaves Dubai's fiscal performance at risk. Gross government debt, including government guarantees but excluding domestic bank loans to the government, increased from 1.6 percent of Dubai and northern emirates GDP in 2007 to 10.3 percent in 2008 and 34 percent as of end-2010. This was mainly due to the bailout of GREs, which was financed through sovereign borrowing. Government debt figures, however, still underestimate Dubai's total public sector debt by omitting quasi-sovereign liabilities. While variable financial conditions suggest that not all across GREs should be considered as a source of fiscal risk, most entities operating in the real estate sector appear to fall in this category. Accordingly, we assume that the debt issued by real estate GREs or their subsidiaries, together with that of those entities currently reporting financial losses, represent a contingent liability to the sovereign balance sheet. On this basis, at least US\$11 billion of contingent risk can be foreseen for the Dubai government by end-2016, with more than 70 percent of that debt coming due in $2011-12 .{ }^{19}$ That would raise the total debt-to-GDP ratio to 47.4 percent in 2012, compared to 34.6 percent for the government alone (Figure III.7). Furthermore, by accounting for all maturing GRE debt as a contingent liability, Dubai's total public sector debt would grow to 62.5 percent of Dubai and northern emirates GDP as of end-2012.

\section{Dubai's debt-to-GDP ratio remains on an increasing path over the medium term.}

Despite gradual fiscal consolidation projected in the baseline scenario, Dubai's government debt is estimated to increase to 41 percent of GDP by the end of 2016. In the absence of fiscal consolidation (i.e., without policy change compared to 2005-09), however, it is projected to reach 53 percent by 2016 . Furthermore, including the potential contingent liabilities as

\footnotetext{
${ }^{18}$ The calculations assume long-term values of the real rate of assets, inflation, and population growth of U.A.E. nationals of 4 percent, 2 percent, and 1.5 percent, respectively. Hydrocarbon reserves are assumed to be depleted by 2082 , and the price of oil is projected to be $\$ 106$ per barrel in 2016 and remain constant in real terms thereafter. A limitation of this analysis is the use of proven hydrocarbon reserves to derive the estimates of long-term fiscal sustainability. This does not account for the possibility that the resource base could be extended and broadened through technological developments and the exploitation of "probable" reserves.

${ }^{19}$ This amount should be regarded as a minimum level of contingent risk. First, the performance of profitable companies operating outside the real estate sector may also be subject to deterioration over the coming years, ultimately triggering sovereign support. Second, other companies, primarily non-listed entities, which do not disclose financial statements, may also be registering losses. Third, for several GREs, the liabilities requiring sovereign support may exceed significantly the level of publicly held debt. Finally, sovereign support may well go beyond guaranteeing the stock of outstanding liabilities and require capital injection. While all these factors should be taken into account when assessing the perimeter of contingent risk, on a more positive note, the net impact of GREs on the sovereign balance sheet might be somewhat lower when assets are accounted for.
} 
estimated above and with the baseline profile for fiscal adjustment, the total debt-to-GDP ratio would increase to 54.3 percent - and 62.5 percent without fiscal consolidation - by the end of 2016. As an extension, including all maturing quasi-sovereign debt would raise Dubai's total public sector debt to 88.6 percent of GDP by 2016. These estimates imply large fiscal costs in case the government needs to support GREs and make fiscal sustainability a serious challenge for Dubai (for detailed projections, see Appendix III.1).

Figure III.7. Dubai: Public Sector Debt Sustainability Analysis, 2002-16
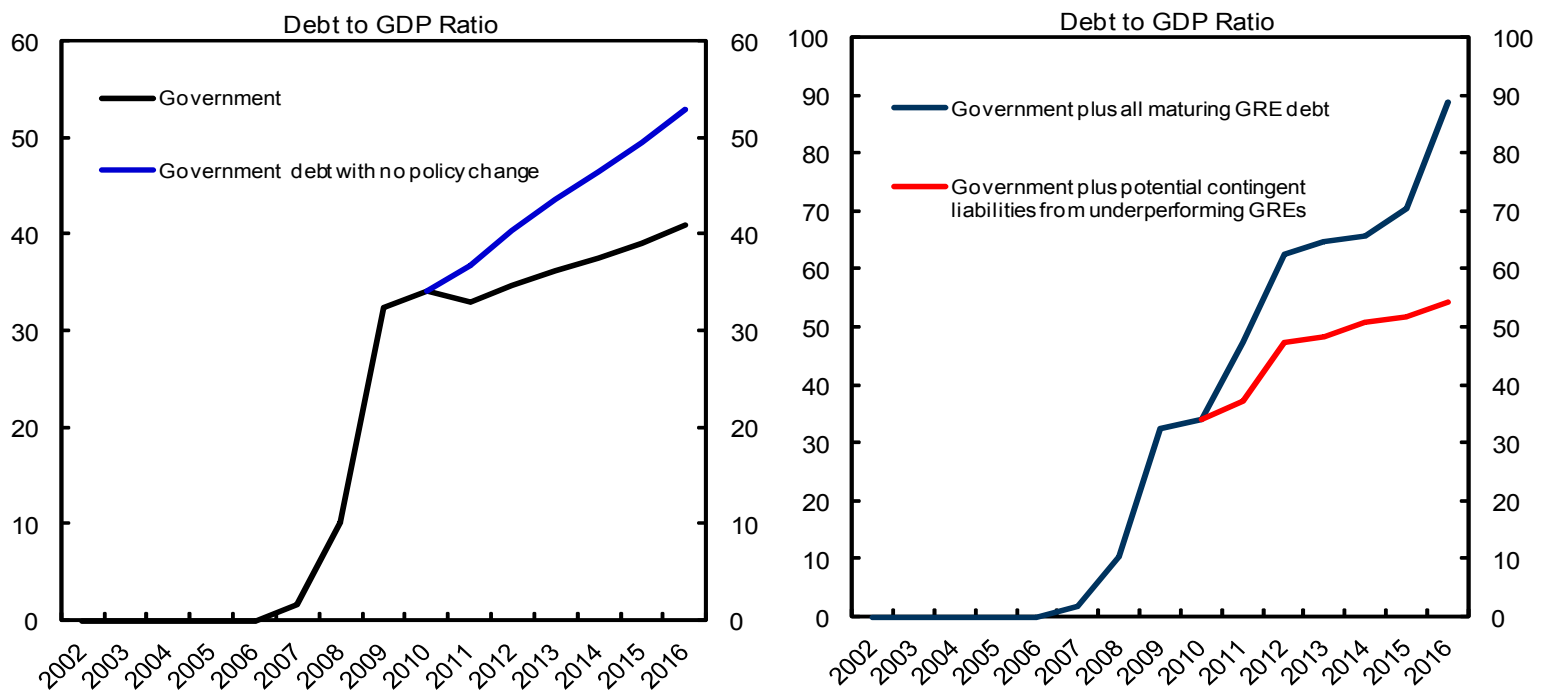

Source: Author's calculations

\section{E. Policy Issues}

71. The expansionary and procyclical fiscal stance aggravated the severity of the crisis. The findings of this paper indicate that the fiscal policy stance has been expansionary and procyclical at the consolidated and sub-national levels prior to the crisis and in 2010 . However, the fiscal policy response to the economic downturn triggered by the global financial crisis was countercyclical in 2009 and has differed substantially from the past and between the emirates, with greater fiscal space for countercyclical measures in the resource-rich emirate of Abu Dhabi. Furthermore, even though the sustainability of public debt is not an immediate issue for the U.A.E. as a whole, there are considerable differences at the sub-national level, especially in view of the build-up of contingent liabilities during the boom years.

\section{Diverging sub-national fiscal performance calls for closer fiscal policy} coordination among the emirates. A medium-term fiscal framework should guide Abu Dhabi's fiscal policy with a view to ensuring long-term sustainability and delinking it from fluctuations in hydrocarbon prices, while the imperative for Dubai should be implement fiscal consolidation to achieve a comfortable debt level over the medium term. These frameworks would need to be complemented at the federal level through a coordination mechanism to avoid procyclicality and reduce fiscal risks. Such coordination requires timely and adequately reliable 
information, particularly on emirates' medium-term fiscal frameworks, annual budgets and their execution, as well as consolidated fiscal accounts to inform policy making.

73. Broader coverage of the public sector is important to contain the fiscal risks of quasi-sovereign entities. The recent GRE bailouts underscore that entities outside the general government can undermine the credibility of fiscal policy if they entail large contingent liabilities. Accordingly, coverage should extend to the broader public sector, along with timely reporting based on a harmonized classification system. To this end, the debt management offices should have dedicated units collecting data on the outstanding GRE liabilities, their maturity profile, and income and cash-flow statements. The authorities should also consider including, as a part of the annual budget documents, a statement of fiscal risks, a discussion on the materialization of risks and forward-looking estimates of risks posed by problematic GREs, and a presentation of policies to mitigate and manage risks. ${ }^{20}$

${ }^{20}$ For an overview of best practices in disclosing fiscal risks, see Everaert, Fouad, Martin, and Velloso (2009). 
Appendix III.1 Dubai: Public Sector Debt Sustainability Framework, 2007-2016

(Percent of Dubai GDP, unless otherwise indicated)

\begin{tabular}{|c|c|c|c|c|c|c|c|c|c|c|}
\hline & \multicolumn{3}{|c|}{ Actual } & \multicolumn{7}{|c|}{ Projections } \\
\hline & 2007 & 2008 & 2009 & 2010 & 2011 & 2012 & 2013 & 2014 & 2015 & 2016 \\
\hline $\begin{array}{l}\text { Baseline: Public sector debt } 1 / \\
\text { o/w foreign-currency denominated }\end{array}$ & $\begin{array}{l}1.6 \\
1.6\end{array}$ & $\begin{array}{l}10.3 \\
10.3\end{array}$ & $\begin{array}{l}32.4 \\
32.4\end{array}$ & $\begin{array}{l}34.0 \\
34.0\end{array}$ & $\begin{array}{l}32.9 \\
32.9\end{array}$ & $\begin{array}{l}34.6 \\
34.6\end{array}$ & $\begin{array}{l}36.1 \\
36.1\end{array}$ & $\begin{array}{l}37.4 \\
37.4\end{array}$ & $\begin{array}{l}39.0 \\
39.0\end{array}$ & $\begin{array}{l}41.0 \\
41.0\end{array}$ \\
\hline Change in public sector debt & 1.6 & 8.6 & 22.2 & 1.6 & -1.2 & 1.7 & 1.5 & 1.3 & 1.6 & 2.0 \\
\hline Identified debt-creating flows $(4+7+12)$ & 0.2 & 1.0 & 15.3 & 2.4 & -4.4 & 2.0 & 2.3 & 1.9 & 2.0 & 2.3 \\
\hline Primary deficit & 0.2 & 1.2 & 12.9 & 2.9 & -0.9 & 1.2 & 1.4 & 1.4 & 1.5 & 1.6 \\
\hline Revenue and grants & 6.6 & 7.5 & 10.6 & 10.8 & 10.7 & 8.2 & 7.8 & 7.5 & 7.1 & 6.8 \\
\hline Primary (noninterest) expenditure & 6.8 & 8.7 & 23.5 & 13.7 & 9.8 & 9.4 & 9.2 & 8.9 & 8.7 & 8.4 \\
\hline Automatic debt dynamics $2 /$ & 0.0 & -0.2 & 2.4 & -0.5 & -3.5 & 0.8 & 0.9 & 0.5 & 0.5 & 0.6 \\
\hline Contribution from interest rate/growth differential $3 /$ & 0.0 & -0.2 & 2.4 & -0.5 & -3.5 & 0.8 & 0.9 & 0.5 & 0.5 & 0.6 \\
\hline Of which contribution from real interest rate & 0.0 & -0.2 & 2.1 & -0.4 & -2.7 & 1.9 & 2.3 & 1.9 & 2.0 & 2.2 \\
\hline Of which contribution from real GDP growth & 0.0 & 0.0 & 0.3 & -0.2 & -0.8 & -1.1 & -1.3 & -1.4 & -1.5 & -1.6 \\
\hline Contribution from exchange rate depreciation $4 /$ & 0.0 & 0.0 & 0.0 & & & & & $\ldots$ & & \\
\hline Other identified debt-creating flows & 0.0 & 0.0 & 0.0 & 0.0 & 0.0 & 0.0 & 0.0 & 0.0 & 0.0 & 0.0 \\
\hline Residual, including asset changes (2-3) 5/ & 1.4 & 7.6 & 6.8 & -0.7 & 3.2 & -0.3 & -0.8 & -0.6 & -0.4 & -0.3 \\
\hline Public sector debt-to-revenue ratio $1 /$ & 24.9 & 137.1 & 306.6 & 315.5 & 307.7 & 421.0 & 462.7 & 500.4 & 547.6 & 601.1 \\
\hline Gross financing need $6 /$ & 0.5 & 2.6 & 20.2 & 21.2 & 18.2 & 19.1 & 20.8 & 25.5 & 21.7 & 23.1 \\
\hline in billions of U.S. dollars & 0.6 & 3.1 & 21.1 & 22.4 & 20.9 & 23.3 & 27.2 & 35.8 & 32.8 & 37.5 \\
\hline \multicolumn{11}{|l|}{ Key Macroeconomic and Fiscal Assumptions Underlying Baseline } \\
\hline Real GDP growth (in percent) & 18.1 & 3.2 & -2.4 & 0.5 & 2.8 & 3.4 & 4.1 & 4.2 & 4.4 & 4.4 \\
\hline Average nominal interest rate on public debt (in percent) $8 /$ & 6.4 & 4.3 & 6.5 & 6.9 & 7.7 & 7.9 & 7.7 & 7.1 & 7.7 & 8.3 \\
\hline Average real interest rate (nominal rate minus change in GDP deflator, in percent) & -2.7 & -11.5 & 17.8 & -1.3 & -9.0 & 6.1 & 7.0 & 5.7 & 5.7 & 6.2 \\
\hline Nominal appreciation (increase in US dollar value of local currency, in percent) & 0.0 & 0.0 & 0.0 & & & & & & & \\
\hline Inflation rate (GDP deflator, in percent) & 9.1 & 15.8 & -11.3 & 8.2 & 16.7 & 1.8 & 0.7 & 1.4 & 2.0 & 2.1 \\
\hline Growth of real primary spending (deflated by GDP deflator, in percent) & 40.2 & 23.8 & 167.8 & -45.4 & -33.6 & 0.3 & 3.7 & 3.2 & 2.3 & 2.6 \\
\hline Primary deficit & 0.2 & 1.2 & 12.9 & 2.9 & -0.9 & 1.2 & 1.4 & 1.4 & 1.5 & 1.6 \\
\hline \multicolumn{11}{|l|}{ A. Alternative Scenarios } \\
\hline A1. No policy change (constant & & & & 34.0 & 36.7 & 40.3 & 43.5 & 46.4 & 49.5 & 52.9 \\
\hline A2. Government plus potential contingent liabilities & & & & 34.0 & 37.0 & 47.4 & 48.2 & 50.7 & 51.7 & 54.3 \\
\hline A3. Government plus 100 percent of maturing GRE debt & & & & 34.0 & 47.4 & 62.5 & 64.6 & 65.7 & 70.4 & 88.6 \\
\hline \multicolumn{11}{|l|}{ B. Bound Tests } \\
\hline B1. Real interest rate & & & & 34.0 & 34.2 & 37.5 & 40.8 & 44.0 & 47.6 & 51.8 \\
\hline B2. Real GDP growth is at historical average minus one standard deviation & & & & 34.0 & 33.3 & 36.2 & 39.6 & 43.3 & 48.0 & 53.6 \\
\hline B3. Primary balance is at historical average minus one standard deviation & & & & 34.0 & 35.0 & 38.9 & 42.7 & 46.2 & 50.0 & 54.3 \\
\hline B4. Combination of B1-B3 using $1 / 2$ standard deviation shocks & & & & 34.0 & 34.9 & 39.3 & 43.7 & 47.9 & 52.7 & 58.1 \\
\hline B5. One time 30 percent real depreciation in 2006 10/ & & & & 34.0 & 59.6 & 62.0 & 64.3 & 66.0 & 67.9 & 70.4 \\
\hline B6. 10 percent of GDP increase in other debt-creating flows in 2006 & & & & 34.0 & 42.9 & 44.8 & 46.7 & 48.1 & 49.8 & 52.0 \\
\hline
\end{tabular}

$1 /$ Indicate coverage of public sector, e.g., general government or nonfinancial public sector. Also whether net or gross debt is used.

2/ Derived as $[(r-\pi(1+g)-g+\alpha \varepsilon(1+r)] /(1+g+\pi+g \pi))$ times previous period debt ratio, with $r=$ interest rate; $\pi=$ growth rate of GDP deflator; $g=$ real GDP growth rate; $\alpha=$ share

of foreign-currency denominated debt; and $\varepsilon=$ nominal exchange rate depreciation (measured by increase in local currency value of U.S. dollar).

$3 /$ The real interest rate contribution is derived from the denominator in footnote $2 / \mathrm{as} r-\pi(1+\mathrm{g})$ and the real growth contribution as $-\mathrm{g}$.

$4 /$ The exchange rate contribution is derived from the numerator in footnote $2 /$ as $\alpha \varepsilon(1+r)$.

$6 /$ Defined as public sector deficit, plus amortization of medium and long-term public sector debt, plus short-term debt at end of previous period.

7/ The key variables include real GDP growth; real interest rate; and primary balance in percent of GDP.

8/ Derived as nominal interest expenditure divided by previous period debt stock.

9/ Assumes that key variables (real GDP growth, real interest rate, and other identified debt-creating flows) remain at the level of the last projection year. 


\section{REFERENCES}

Abdih, Y., P. Lopez-Murphy, A. Roitman, and R. Sahay, 2010, "The Cyclicality of Fiscal Policy in the Middle East and Central Asia: Is the Current Crisis Different?," IMF Working Paper, No. WP/10/68.

Baskaran, T., and L. Feld, 2009, "Fiscal Decentralization and Economic Growth in OECD Countries: Is There a Relationship?,” CESIFO Working Paper, No. 2721.

Baxter, M., and R. King, 1999, "Measuring Business Cycles: Approximate Band-Pass Filters for Economic Time Series," Review of Economics and Statistics, Vol. 81, pp. 573-593.

Crivelli, E., and K. Staal, 2006, "Size and Soft Budget Constraints," CESIFO Working Paper, No. 1858.

Davoodi, H., and H. Zou, 1998, "Fiscal Decentralization and Economic Growth: A CrossCountry Study,” Journal of Urban Economics, Vol. 43, pp. 244-257.

Everaert, G., M. Fouad, E. Martin, and R. Velloso, 2009, "Disclosing Fiscal Risks in the Post-Crisis World," IMF Staff Position Note, SPN/09/18.

Filc, G., and C. Scartascini, 2007, "Budgetary Institutions," in The State of State Reform in Latin America, edited by E. Lora, Washington, DC: Inter-American Development Bank.

Gramlich, E., 1977, "Intergovernmental Grants: A Review of the Empirical Literature," in The Political Economy of Fiscal Federalism, edited by W. Oates, Lexington, Mass.: Lexington Press.

Hodrick, R., and E. Prescott, 1997, "Post-war Business Cycles: An Empirical Investigation," Journal of Money, Credit, and Banking, Vol. 29, pp. 1-16.

Horton, M., M. Kumar, and P. Mauro, 2009, “The State of Public Finances: A Cross Country Fiscal Monitor," IMF Staff Position Note, No. 09/21.

Hunter, J., 1974, "Vertical Intergovernmental Financial Imbalance: A Framework for Evaluation," Finanzarchiv, No. 2, pp. 481-492.

Musgrave, R., 1959, The Theory of Public Finance, New York: McGraw Hill.

Oates, W., 1972, Fiscal Federalism, New York: Harcourt Brace Jovanovich. 
Ravn, M., and H. Uhlig, 2002, "On Adjusting the Hodrick-Prescott Filter for the Frequency of Observations," Review of Economics and Statistics, Vol. 85, pp. 235-243.

Rodriguez-Pose, A., and A. Bwire, 2004, "The Economic (In) efficiency of Devolution," Environment and Planning, Vol. 36, pp. 1907-1928.

Rubinfield, D., 1987, "The Economics of the Local Public Sector," in Handbook of Public Economics, edited by A. Auerbach and M. Feldstein, Amsterdam: North-Holland.

Ter-Minassian, T., 2006, "Fiscal Rules for Subnational Governments: Can They Promote Fiscal Discipline," OECD Journal on Budgeting, Vol. 6, No. 3, pp. 111-121.

Tiebout, C., 1956, “A Pure Theory of Local Expenditures,” Journal of Political Economy, Vol. 64, No. 5, pp. 416-424.

Wildasin, D., 1997, "Externalities and Bailouts: Hard and Soft Budget Constraints in Intergovernmental Fiscal Relations," World Bank Policy Research Working Paper, No. 1843.

Wilde, J., 1971, “Grants-in-Aid: The Analytics of Designs and Response," National Tax Journal, Vol. 24, pp. 143-155.

Woller, G., and K. Phillips 1998, "Fiscal Decentralization and Economic Growth: An Empirical Investigation,” Journal of Development Studies, Vol. 34, pp. 139-148. 


\section{Statistical ApPendix}

Table 1. United Arab Emirates: Sectoral Origin of GDP at Current Prices, 2002-10 ${ }^{1}$

(Millions of U.A.E. dirhams)

\begin{tabular}{|c|c|c|c|c|c|c|c|c|c|}
\hline & 2002 & 2003 & 2004 & 2005 & 2006 & 2007 & 2008 & 2009 & 2010 \\
\hline Gross domestic product & 403,300 & 456,662 & 542,885 & 663,316 & 815,684 & 948,056 & $1,156,267$ & 992,805 & 1093114 \\
\hline Crude oil production (including natural gas) & 93,705 & 114,781 & 158,087 & 227,231 & 304,762 & 320,349 & 427,666 & 287,206 & 343,932 \\
\hline Other production (sum) & 321,524 & 355,334 & 400,384 & 458,194 & 535,541 & 662,275 & 773,879 & 752,321 & 797,325 \\
\hline Agriculture & 8,886 & 8,803 & 9,041 & 9,256 & 8,926 & 9,251 & 9,585 & 9,581 & 9,590 \\
\hline Industry (sum) & 98,047 & 109,536 & 122,467 & 141,862 & 167,568 & 199,096 & 243,903 & 242,811 & 263,015 \\
\hline Quarrying & 701 & 747 & 825 & 974 & 1,289 & 1,496 & 1,439 & 1,377 & 1,436 \\
\hline Manufacturing $^{2}$ & 52,685 & 55,998 & 62,499 & 70,365 & 78,774 & 85,490 & 99,641 & 100,345 & 106,263 \\
\hline Electricity, gas and water & 6,917 & 8,703 & 10,129 & 12,611 & 15,096 & 17,396 & 20,581 & 23,818 & 27,983 \\
\hline Construction & 37,744 & 44,088 & 49,014 & 57,912 & 72,408 & 94,714 & 122,242 & 117,270 & 127,333 \\
\hline Services (sum) & 214,591 & 236,995 & 268,876 & 307,075 & 359,047 & 453,928 & 520,392 & 499,929 & 524,720 \\
\hline Trade & 83,684 & 90,040 & 95,647 & 103,466 & 123,093 & 150,105 & 168,946 & 154,258 & 163,075 \\
\hline Wholesale and retail trade & 73,215 & 78,797 & 83,738 & 90,108 & 107,262 & 132,166 & 147,590 & 133,555 & 139,959 \\
\hline Restaurants and hotels & 10,469 & 11,243 & 11,908 & 13,358 & 15,831 & 17,939 & 21,356 & 20,702 & 23,116 \\
\hline $\begin{array}{l}\text { Transportation, storage, } \\
\text { and communication }\end{array}$ & 34,235 & 37,731 & 46,344 & 52,196 & 61,989 & 76,088 & & 92,482 & 98,978 \\
\hline Finance and insurance & 22,041 & 24,929 & 29,791 & 42,195 & 51,090 & 67,872 & 73,185 & 71,842 & 74,320 \\
\hline business services & 45,549 & 52,422 & 62,802 & 71,171 & 81,495 & 111,180 & 125,697 & 106,685 & 108,413 \\
\hline Government & 18,410 & & 20,881 & 23 , & 24,478 & 28,434 & & 47,809 & 49,865 \\
\hline Other & 10,671 & 11,956 & & $14, \varsigma$ & 16,903 & 20,248 & 25 , & 26,853 & 30,069 \\
\hline Social and personal se & 8,646 & 9,781 & 11,163 & 12,147 & 13,736 & 16,666 & 20,859 & 22,587 & 25,936 \\
\hline Domestic household services & 2,025 & 2,175 & 2,249 & 2,769 & 3,166 & 3,582 & 4,158 & 4,266 & 4,133 \\
\hline Less: imputed bank charges & 11,930 & 13,453 & 15,586 & 22,109 & 24,619 & 34,567 & 45,277 & 46,722 & 48,143 \\
\hline
\end{tabular}

Source: National Bureau of Statistics.

${ }^{1} \mathrm{GDP}$ at Market prices

${ }^{2}$ Includes natural gas and petrolemum processing industries. 
Table 2. United Arab Emirates: Use of Resources at Current Prices, 2002-10

(Millions of U.A.E. dirhams)

\begin{tabular}{|c|c|c|c|c|c|c|c|c|c|}
\hline & 2002 & 2003 & 2004 & 2005 & 2006 & 2007 & 2008 & 2009 & 2010 \\
\hline Total consumption & 291,513 & 315,172 & 380,986 & 432,086 & 522,122 & 647,294 & 789,219 & 701,402 & 716,547 \\
\hline Public & 35,388 & 38,661 & 42,286 & 45,544 & 50,961 & 56,190 & 66,570 & 89,301 & 90,141 \\
\hline Private & 256,125 & 276,511 & 338,700 & 386,542 & 471,161 & 591,104 & 722,649 & 612,101 & 626,406 \\
\hline Total fixed investment & 84,981 & 94,947 & 101,433 & 121,911 & 141,822 & 217,835 & 244,967 & 221,252 & 260,230 \\
\hline Public & 36,019 & 40,649 & 43,602 & 46,551 & 54,690 & 64,189 & 85,073 & 89,857 & 94,401 \\
\hline Private & 48,962 & 54,298 & 57,831 & 75,360 & 87,132 & 153,646 & 159,894 & 131,395 & 165,829 \\
\hline Change in inventories & 2,870 & 2,950 & 3,392 & 5,724 & 6,663 & 7,435 & 15,235 & 15,728 & 16,023 \\
\hline Gross capital formation & 87,851 & 97,897 & 104,825 & 127,635 & 148,485 & 225,270 & 260,202 & 236,980 & 276,253 \\
\hline Domestic expenditure & 379,364 & 413,069 & 485,811 & 559,721 & 670,607 & 872,564 & $1,049,421$ & 938,382 & 992,800 \\
\hline Net exports of goods \& services & 23,936 & 43,594 & 57,073 & 103,595 & 145,076 & 75,492 & 106,847 & 54,423 & 100,314 \\
\hline Exports & 199,647 & 255,380 & 345,100 & 448,305 & 559,813 & 685,620 & 913,748 & 741,694 & 851,939 \\
\hline Goods & 190,142 & 245,160 & 334,013 & 430,737 & 534,666 & 656,020 & 878,508 & 704,394 & 811,339 \\
\hline Hydrocarbons & 83,755 & 107,175 & 142,496 & 202,277 & 257,442 & 271,128 & 374,915 & 249,273 & 307,400 \\
\hline Other goods exports & 106,387 & 137,985 & 191,517 & 228,460 & 277,224 & 384,892 & 503,593 & 455,121 & 503,939 \\
\hline Services & 9,505 & 10,220 & 11,087 & 17,568 & 25,147 & 29,600 & 35,240 & 37,300 & 40,600 \\
\hline Imports & 175,711 & 211,786 & 288,027 & 344,710 & 414,737 & 610,128 & 806,901 & 687,271 & 751,625 \\
\hline Goods & 156,641 & 191,241 & 264,361 & 310,890 & 367,459 & 551,328 & 735,701 & 624,771 & 673,625 \\
\hline Services & 19,070 & 20,545 & 23,666 & 33,820 & 47,278 & 58,800 & 71,200 & 62,500 & 78,000 \\
\hline GDP at market prices & 403,300 & 456,662 & 542,885 & 663,316 & 815,684 & 948,056 & $1,156,267$ & 992,805 & $1,093,114$ \\
\hline
\end{tabular}

Source: National Bureau of Statistics. 
Table 3. United Arab Emirates: Oil and Gas Production, Exports, and Prices, 2002-10

\begin{tabular}{|c|c|c|c|c|c|c|c|c|c|}
\hline & 2002 & 2003 & 2004 & 2005 & 2006 & 2007 & 2008 & 2009 & 2010 \\
\hline & \multicolumn{9}{|c|}{ (In million barrels per day) } \\
\hline \multicolumn{10}{|l|}{ Oil production } \\
\hline Crude oil, incld condensates & 2.26 & 2.59 & 2.66 & 2.68 & 2.89 & 2.80 & 2.84 & 2.61 & 2.75 \\
\hline Crude oil & 1.93 & 2.26 & 2.33 & 2.38 & 2.60 & 2.53 & 2.57 & 2.32 & 2.39 \\
\hline Abu Dhabi & 1.77 & 2.10 & 2.17 & 2.24 & 2.46 & 2.42 & 2.49 & 2.24 & 2.31 \\
\hline Dubai, Sharjah, and Ras AI Khaimah & 0.16 & 0.16 & 0.16 & 0.14 & 0.14 & 0.11 & 0.08 & 0.08 & 0.08 \\
\hline Condensates & 0.33 & 0.33 & 0.33 & 0.30 & 0.29 & 0.27 & 0.27 & 0.29 & 0.36 \\
\hline Refinery output & 0.56 & 0.56 & 0.56 & 0.54 & 0.59 & 0.57 & 0.56 & 0.57 & 0.57 \\
\hline Oil and product exports & 2.18 & 2.48 & 2.47 & 2.46 & 2.65 & 2.53 & 2.58 & 2.19 & 2.25 \\
\hline Crude oil \& condensates & 1.85 & 2.16 & 2.19 & 2.21 & 2.43 & 2.36 & 2.42 & 2.09 & 2.15 \\
\hline Abu Dhabi & 1.61 & 1.92 & 2.01 & 2.05 & 2.27 & 2.23 & 2.33 & 2.00 & 2.06 \\
\hline Dubai, Sharjah, and Ras AI Khaimah & 0.16 & 0.16 & 0.16 & 0.14 & 0.14 & 0.11 & 0.08 & 0.08 & 0.08 \\
\hline Condensates & 0.08 & 0.08 & 0.02 & 0.02 & 0.02 & 0.02 & 0.01 & 0.01 & 0.01 \\
\hline \multirow[t]{2}{*}{ Refined products } & 0.33 & 0.32 & 0.28 & 0.25 & 0.22 & 0.17 & 0.16 & 0.10 & 0.10 \\
\hline & \multicolumn{9}{|c|}{ (In billion cubic meters) } \\
\hline Natural gas production & 43.40 & 44.40 & 46.30 & 47.80 & 49.00 & 50.40 & 50.20 & 51.70 & 54.29 \\
\hline LNG exports & 7.11 & 7.40 & 7.41 & 7.50 & 7.77 & 7.72 & 7.57 & 7.69 & 7.98 \\
\hline NGL exports & 11.92 & 13.10 & 12.86 & 13.24 & 13.57 & 12.50 & 12.41 & 12.79 & 13.43 \\
\hline \multirow[t]{2}{*}{ Domestic gas consumption } & 36.40 & 37.50 & 40.20 & 42.10 & 43.40 & 49.30 & 58.10 & 62.75 & 69.02 \\
\hline & \multicolumn{9}{|c|}{ (In U.S. dollar million) } \\
\hline Oil and product exports & 19,556 & 25,322 & 34,027 & 49,307 & 62,935 & 65,682 & 91,446 & 59,571 & 66,769 \\
\hline Crude oil \& condensates & 16,050 & 21,592 & 29,875 & 43,867 & 57,230 & 60,819 & 85,428 & 54,125 & 60,089 \\
\hline Abu Dhabi & 13,969 & 19,272 & 27,602 & 40,845 & 53,574 & 57,679 & 82,210 & 51,819 & 57,344 \\
\hline Dubai and others & 1,341 & 1,539 & 2,046 & 2,619 & 3,191 & 2,727 & 2,736 & 2,032 & 2,493 \\
\hline Condensates & 740 & 781 & 227 & 403 & 465 & 413 & 482 & 274 & 252 \\
\hline \multirow[t]{2}{*}{ Refined products } & 3,506 & 3,730 & 4,152 & 5,440 & 5,705 & 4,863 & 6,018 & 5,446 & 6,680 \\
\hline & \multicolumn{9}{|c|}{ (In U.S. dollar million) } \\
\hline LNG and NGL exports & 3,250 & 3,861 & 4,773 & 5,771 & 7,165 & 8,145 & 11,546 & 8,577 & 10,744 \\
\hline LNG exports & 1,221 & 1,182 & 1,506 & 1,601 & 2,047 & 2,511 & 4,567 & 3,395 & 4,605 \\
\hline NGL exports & 2,029 & 2,679 & 3,267 & 4,170 & 5,118 & 5,634 & 6,979 & 5,182 & 6,139 \\
\hline \multirow[t]{2}{*}{ Total hydrocarbon exports } & 22,806 & 29,183 & 38,800 & 55,078 & 70,100 & 73,827 & 102,992 & 68,148 & 77,512 \\
\hline & \multicolumn{9}{|c|}{ (In U.S. dollar per barrel) } \\
\hline \multicolumn{10}{|l|}{ Memorandum item: } \\
\hline Average UAE oil export prices & 24.64 & 28.24 & 35.87 & 52.32 & 63.54 & 71.08 & 96.70 & 62.79 & 77.02 \\
\hline Avg Abu Dhabi crude oil export price & 24.64 & 27.96 & 36.11 & 52.52 & 63.67 & 71.34 & 96.66 & 62.79 & 77.01 \\
\hline
\end{tabular}

Sources: ADNOC; Fund staff estimates. 
Table 4. United Arab Emirates: Population by Emirate, 2002-09

(In thousands)

\begin{tabular}{lrrrrrrrr}
\hline & 2002 & 2003 & 2004 & 2005 & 2006 & 2007 & 2008 & 2009 \\
\hline Abu Dhabi & 1,204 & 1,257 & 1,312 & 1,399 & 1,430 & 1,493 & 1,559 & 1,628 \\
Dubai & 1,020 & 1,098 & 1182 & 1321 & 1,372 & 1,478 & 1,596 & 1,722 \\
Sharjah & 623 & 667 & 715 & 794 & 821 & 882 & 946 & 1,017 \\
Ajman & 171 & 182 & 190 & 207 & 212 & 224 & 237 & 250 \\
Umm al Qaiwan & 43 & 46 & 48 & 49 & 50 & 52 & 53 & 56 \\
Ras al Khaimah & 184 & 191 & 198 & 210 & 214 & 222 & 231 & 241 \\
Fujaira & 104 & 110 & 116 & 126 & 130 & 137 & 143 & 152 \\
Total & 3,349 & 3,551 & 3,761 & 4,106 & 4,229 & 4,488 & 4,765 & 5,066 \\
\hline
\end{tabular}

Source: National Bureau of Statistics.

Table 5. United Arab Emirates: Sectoral Distribution of Civilian Employment, 2002-08 (In thousands)

\begin{tabular}{lrrrrrrr}
\hline & 2002 & 2003 & 2004 & 2005 & 2006 & 2007 & 2008 \\
\hline Civilian employment & 2,176 & 2,334 & 2,461 & 2,623 & 2,844 & 3,096 & 3,397 \\
Oil sector & 27 & 28 & 30 & 33 & 33 & 39 & 40 \\
Other sectors & 2,149 & 2,306 & 2,431 & 2,590 & 2,811 & 3,057 & 3,357 \\
Agriculture & 163 & 166 & 169 & 191 & 193 & 225 & 233 \\
Industry & 728 & 806 & 852 & 901 & 1,049 & 1,064 & 1,234 \\
$\quad$ Mining and quarrying & 5 & 5 & 6 & 5 & 6 & 6 & 7 \\
Manufacturing 2 & 276 & 299 & 319 & 333 & 362 & 393 & 431 \\
Electricity, gas, and water & 27 & 28 & 29 & 34 & 34 & 40 & 39 \\
Construction & 420 & 474 & 498 & 529 & 647 & 624 & 757 \\
Services & 1,258 & 1,334 & 1,410 & 1,498 & 1,569 & 1,768 & 1,891 \\
$\quad$ Trade & 511 & 549 & 589 & 612 & 643 & 723 & 789 \\
$\quad$ Wholesale and retail trade & 416 & 450 & 479 & 497 & 519 & 587 & 643 \\
$\quad$ Restaraunts and hotels & 95 & 99 & 110 & 115 & 124 & 136 & 146 \\
$\quad$ Transport and communications & 131 & 143 & 148 & 161 & 174 & 190 & 204 \\
Finance and insurance & 26 & 26 & 27 & 31 & 37 & 41 & 42 \\
Real estate & 64 & 67 & 74 & 77 & 84 & 90 & 97 \\
Government services & 237 & 250 & 265 & 283 & 284 & 329 & 353 \\
Social and personal services & 91 & 99 & 107 & 114 & 121 & 134 & 142 \\
$\quad$ Domestic households sevices & 198 & 200 & 200 & 220 & 226 & 260 & 264 \\
\hline
\end{tabular}

Source: Ministry of Planning.

${ }^{1}$ Excludes defence personnel and visitors to the U.A.E.

${ }^{2}$ Includes natural gas and petroleum processing industries. 
Table 6. United Arab Emirates: Consumer Price Index by Major Components, 2009-10

(Index 2007=100)

\begin{tabular}{|c|c|c|c|c|c|c|c|c|c|c|c|c|c|}
\hline \multicolumn{14}{|c|}{2009} \\
\hline & Weights & Jan & Feb & Mar & Apr & May & Jun & Jul & Aug & Sep & Oct & Nov & Dec \\
\hline All Items & 100.0 & 114.7 & 114.3 & 113.4 & 113.2 & 113.0 & 113.1 & 113.5 & 114.0 & 114.7 & 114.6 & 115.1 & 114.4 \\
\hline Food \& beverages & 13.9 & 117.8 & 117.2 & 114.7 & 114.3 & 115.1 & 115.9 & 116.7 & 118.3 & 118.3 & 118.8 & 119.6 & 119.7 \\
\hline Alcohol \& beverages & 0.2 & 111.4 & 112.9 & 112.9 & 115.5 & 115.5 & 115.6 & 115.5 & 115.6 & 115.6 & 115.6 & 115.6 & 115.6 \\
\hline Clothing \& footwear & 7.6 & 117.4 & 116.6 & 115.1 & 115.9 & 114.8 & 113.8 & 113.6 & 112.2 & 113.8 & 111.6 & 112.3 & 111.6 \\
\hline Housing & 39.3 & 115.4 & 115.2 & 113.6 & 113.3 & 112.1 & 112.1 & 112.9 & 114.3 & 114.8 & 114.9 & 114.9 & 113.5 \\
\hline Furniture and other items & 4.2 & 112.0 & 108.8 & 110.0 & 110.4 & 113.3 & 113.7 & 115.9 & 114.4 & 114.3 & 113.7 & 119.2 & 117.2 \\
\hline Medical care \& health services & 1.1 & 108.4 & 108.4 & 106.9 & 106.5 & 106.1 & 105.9 & 104.8 & 105.8 & 105.0 & 105.9 & 106.1 & 104.4 \\
\hline Transportation & 9.9 & 111.4 & 111.4 & 111.8 & 111.5 & 111.8 & 111.8 & 111.3 & 110.7 & 109.9 & 109.4 & 109.2 & 109.5 \\
\hline Communication & 6.9 & 104.2 & 104.2 & 104.2 & 104.1 & 104.1 & 104.1 & 104.1 & 104.1 & 104.2 & 104.2 & 104.2 & 104.2 \\
\hline Recreation \& cultural services & 3.1 & 103.2 & 102.7 & 103.7 & 102.6 & 104.7 & 104.8 & 105.0 & 104.8 & 104.7 & 105.0 & 105.7 & 106.0 \\
\hline Education & 4.0 & 115.2 & 115.2 & 115.2 & 115.2 & 115.2 & 115.2 & 115.2 & 115.2 & 127.3 & 127.3 & 127.3 & 127.3 \\
\hline Hotels \& restaurants & 4.4 & 128.7 & 128.7 & 129.7 & 129.0 & 130.1 & 130.1 & 129.8 & 129.9 & 130.1 & 130.3 & 130.3 & 129.8 \\
\hline Other goods \& services & 5.3 & 115.9 & 115.9 & 115.3 & 115.6 & 116.1 & 116.4 & 115.7 & 115.4 & 114.8 & 114.6 & 116.0 & 116.5 \\
\hline
\end{tabular}

\begin{tabular}{|c|c|c|c|c|c|c|c|c|c|c|c|c|c|}
\hline & Weights & Jan & Feb & Mar & Apr & May & Jun & Jul & Aug & Sep & Oct & Nov & Dec \\
\hline All Items & 100.0 & 114.2 & 114.0 & 114.1 & 114.1 & 114.0 & 114.1 & 114.5 & 115.1 & 116.1 & 116.7 & 116.8 & 116.4 \\
\hline Food \& beverages & 13.9 & 119.8 & 118.9 & 118.0 & 119.5 & 120.9 & 121.0 & 121.0 & 123.3 & 126.7 & 127.2 & 127.4 & 125.4 \\
\hline Alcohol \& beverages & 0.2 & 115.9 & 116.1 & 116.1 & 116.1 & 116.1 & 116.1 & 116.1 & 116.5 & 116.5 & 116.5 & 116.5 & 116.5 \\
\hline Clothing \& footwear & 7.6 & 111.5 & 110.4 & 110.3 & 109.3 & 109.4 & 109.2 & 107.9 & 107.0 & 107.1 & 106.6 & 106.8 & 105.4 \\
\hline Housing & 39.3 & 114.0 & 113.6 & 114.2 & 113.4 & 112.8 & 113.1 & 112.8 & 112.8 & 113.0 & 114.4 & 114.4 & 114.3 \\
\hline Furniture and other items & 4.2 & 118.2 & 118.0 & 118.0 & 118.4 & 118.2 & 117.6 & 118.5 & 119.8 & 119.3 & 120.1 & 120.2 & 120.2 \\
\hline Medical care \& health services & 1.1 & 104.9 & 105.1 & 105.3 & 105.3 & 105.3 & 105.3 & 105.3 & 105.3 & 105.3 & 105.3 & 105.3 & 105.3 \\
\hline Transportation & 9.9 & 109.4 & 110.3 & 110.3 & 111.5 & 112.0 & 112.4 & 116.3 & 117.0 & 118.9 & 118.8 & 118.7 & 119.0 \\
\hline Communication & 6.9 & 98.0 & 98.4 & 98.4 & 97.8 & 97.6 & 97.6 & 97.6 & 98.4 & 98.4 & 98.5 & 98.4 & 98.2 \\
\hline Recreation \& cultural services & 3.1 & 106.3 & 106.7 & 106.9 & 106.3 & 106.3 & 106.3 & 106.6 & 111.3 & 113.7 & 114.0 & 113.8 & 113.8 \\
\hline Education & 4.0 & 127.3 & 127.3 & 127.3 & 127.3 & 127.6 & 127.4 & 127.4 & 127.4 & 131.9 & 131.9 & 131.9 & 131.9 \\
\hline Hotels \& restaurants & 4.4 & 129.5 & 130.2 & 130.2 & 130.2 & 131.1 & 131.3 & 131.2 & 131.3 & 131.3 & 131.3 & 131.3 & 131.3 \\
\hline Other goods \& services & 5.3 & 116.5 & 116.5 & 116.6 & 117.7 & 115.2 & 115.6 & 117.0 & 117.4 & 117.9 & 118.7 & 119.0 & 119.6 \\
\hline
\end{tabular}

Source: National Bureau of Statistics. 
Table 7. United Arab Emirates: Consolidated Government Finances, 2002-10

(Millions of U.A.E. dirhams)

\begin{tabular}{|c|c|c|c|c|c|c|c|c|c|}
\hline & 2002 & 2003 & 2004 & 2005 & 2006 & 2007 & 2008 & 2009 & 2010 \\
\hline Total revenue & 77,509 & 99,490 & 125,978 & 196,740 & 275,047 & 313,387 & 446,795 & 250,914 & 315,048 \\
\hline Hydrocarbon ${ }^{1}$ & 54,631 & 75,162 & 98,584 & 150,664 & 216,559 & 233,626 & 361,515 & 174,091 & 239,271 \\
\hline Nonhydrocarbon & 22,878 & 24,328 & 27,395 & 46,076 & 58,488 & 79,761 & 85,280 & 76,822 & 75,778 \\
\hline Customs & 1,663 & 2,449 & 3,040 & 3,852 & 4,687 & 8,101 & 8,686 & 8,186 & 8,588 \\
\hline Profit transfers & 3,357 & 2,935 & 3,322 & 4,624 & 5,660 & 12,701 & 5,228 & 4,033 & 3,974 \\
\hline Income tax ${ }^{2}$ & 235 & 301 & 320 & 420 & 1,093 & 842 & 1,190 & 1,340 & 1,387 \\
\hline Fees and charges & 6,429 & 9,479 & 7,044 & 14,998 & 13,566 & 9,719 & 24,051 & 24,340 & 25,376 \\
\hline Investment income ${ }^{3}$ & 6,587 & 4,054 & 5,965 & 13,549 & 23,107 & 30,797 & 23,167 & 16,596 & 13,106 \\
\hline Other & 4,607 & 5,110 & 7,703 & 8,634 & 10,374 & 17,600 & 22,958 & 22,326 & 23,346 \\
\hline Total expenditure and grants & 85,898 & 91,614 & 96,131 & 104,431 & 127,476 & 167,755 & 259,612 & 381,458 & 338,454 \\
\hline Current expenditure & 71,710 & 74,306 & 80,984 & 84,256 & 106,545 & 127,439 & 172,724 & 216,447 & 248,666 \\
\hline Wages and salaries ${ }^{4}$ & 15,120 & 15,764 & 15,990 & 15,915 & 18,138 & 21,003 & 29,001 & 32,711 & 33,377 \\
\hline Goods and services & 23,744 & 27,029 & 28,326 & 25,453 & 25,330 & 36,455 & 49,179 & 67,738 & 84,953 \\
\hline Abu Dhabi "federal services" 5 & 17,045 & 19,251 & 23,760 & 22,784 & 25,349 & 31,285 & 45,552 & 55,924 & 72,365 \\
\hline Subsidies and transfers ${ }^{6}$ & 15,406 & 11,370 & 12,335 & 19,353 & 37,035 & 36,425 & 41,154 & 45,479 & 37,943 \\
\hline Interest payments & 0 & 0 & 0 & 0 & 1 & 413 & 3,047 & 5,880 & 9,473 \\
\hline Other & 395 & 892 & 573 & 751 & 692 & 1,858 & 4,790 & 8,716 & 10,556 \\
\hline Development expenditure & 12,468 & 16,028 & 15,064 & 14,042 & 11,606 & 17,271 & 31,485 & 45,083 & 38,746 \\
\hline Loans and equity (net) ${ }^{7}$ & 760 & 16 & -514 & 5,118 & 8,953 & 20,793 & 51,844 & 116,641 & 49,874 \\
\hline Foreign grants ${ }^{8}$ & 960 & 1,264 & 597 & 1,015 & 372 & 2,252 & 3,559 & 3,287 & 1,168 \\
\hline Abu Dhabi & 784 & 1,136 & 597 & 1,015 & 372 & 2,129 & 3,485 & 3,096 & 1,158 \\
\hline Federal & 176 & 128 & 0 & 0 & 0 & 123 & 74 & 191 & 10 \\
\hline Overall balance (consolidated) ${ }^{9}$ & $-8,389$ & 7,876 & 29,848 & 92,309 & 147,572 & 146,045 & 190,230 & $-124,665$ & $-13,932$ \\
\hline (In percent of GDP) & -2.1 & 1.7 & 5.5 & 13.9 & 18.1 & 15.4 & 16.5 & -12.6 & -1.3 \\
\hline Nonhydrocarbon balance & $-63,020$ & $-67,286$ & $-68,736$ & $-58,355$ & $-68,987$ & $-87,582$ & $-171,285$ & $-298,756$ & $-253,203$ \\
\hline (In percent of nonhydrocarbon GDP) & -20.4 & -19.7 & -17.9 & -13.4 & -13.5 & -14.0 & -23.5 & -42.3 & -34.7 \\
\hline Nonhydrocarbon balance (excluding investment income & $-69,607$ & $-71,340$ & $-74,701$ & $-71,904$ & $-92,094$ & $-118,379$ & $-194,452$ & $-315,352$ & $-266,309$ \\
\hline (In percent of nonhydrocarbon GDP) & -22.5 & -20.9 & -19.4 & -16.5 & -18.0 & -18.9 & -26.7 & -44.7 & -36.5 \\
\hline Financing & 8,389 & $-7,876$ & $-29,848$ & $-92,309$ & $-147,572$ & $-146,045$ & $-190,230$ & 124,665 & 13,932 \\
\hline Bank financing, net ${ }^{10}$ & $-8,482$ & $-2,269$ & $-1,776$ & $-16,039$ & $-4,550$ & $-9,498$ & $-23,652$ & 95,051 & 19,335 \\
\hline Loans to government & 4,292 & 5,613 & 10,509 & 13,369 & 11,477 & 13,682 & 70,604 & 78,830 & 9,279 \\
\hline Government deposits & 12,774 & 7,882 & 12,285 & 29,408 & 16,027 & 23,180 & 94,256 & $-16,221$ & $-10,056$ \\
\hline Of which: Privatization receipts ${ }^{11}$ & 0 & 3,004 & 2 & 6,207 & 0 & 0 & 0 & 0 & 0 \\
\hline Nonbank financing & 16,871 & $-5,607$ & $-28,072$ & $-76,270$ & $-143,022$ & $-136,547$ & $-166,578$ & 29,614 & $-5,403$ \\
\hline \multicolumn{10}{|l|}{ Memorandum items: } \\
\hline Hydrocarbon share of revenue & 70.5 & 75.5 & 78.3 & 76.6 & 78.7 & 74.5 & 80.9 & 69.4 & 75.9 \\
\hline \multicolumn{10}{|c|}{ Sources: Federal government; Emirate finance departments; and Fund staff estimates. } \\
\hline \multicolumn{10}{|c|}{${ }^{1}$ Includes Fund estimates of revenues from other government entities operating in the oil and gas sector. } \\
\hline \multicolumn{10}{|c|}{${ }^{2}$ Taxes on profit of foreign banks. Income taxes on gas companies are included under hydrocarbon revenues. } \\
\hline \multicolumn{10}{|l|}{${ }^{3}$ Fund staff estimates. } \\
\hline \multicolumn{10}{|l|}{${ }^{4}$ Excludes military wages and salaries. } \\
\hline \multicolumn{10}{|c|}{${ }^{5}$ Largely military and internal security expenditures paid by Abu Dhabi but not in the federal accounts. } \\
\hline \multicolumn{10}{|c|}{${ }^{6}$ Includes government's contribution to the pension fund in 2005 of AED 6,207 million. } \\
\hline \multicolumn{10}{|c|}{${ }^{7}$ Includes government's share in the 2005 privatization of the telecom company, Etisalat. } \\
\hline \multicolumn{10}{|c|}{${ }^{8}$ Intragovernmental grants are netted out in the consolidated fiscal accounts. } \\
\hline \multicolumn{10}{|c|}{${ }^{9}$ Consolidated accounts of the federal government, Abu Dhabi, Dubai and Sharjah. } \\
\hline${ }^{10}$ From the monetary statistics. & & & & & & & & & \\
\hline & & & & & & & & & \\
\hline
\end{tabular}


Table 8. United Arab Emirates: Federal Government Financial Operations, 2002-10 (Millions of U.A.E. dirhams)

\begin{tabular}{|c|c|c|c|c|c|c|c|c|c|}
\hline & 2002 & 2003 & 2004 & 2005 & 2006 & 2007 & 2008 & 2009 & 2010 \\
\hline Total revenue and grants & 21,687 & 21,310 & 22,016 & 24,939 & 30,387 & 34,541 & 42,802 & 42,280 & 39,799 \\
\hline Revenues & 8,508 & 8,253 & 9,018 & 11,426 & 16,286 & 20,146 & 26,610 & 26,780 & 27,728 \\
\hline Enterprise profits ${ }^{1}$ & 2,120 & 1,817 & 2,011 & 2,687 & 2,853 & 11,231 & 3,409 & 3,263 & 3,204 \\
\hline Other fees and charges & 6,388 & 6,436 & 7,007 & 8,740 & 13,433 & 8,915 & 23,201 & 23,517 & 24,524 \\
\hline Grants from Emirates & 13,179 & 13,057 & 12,998 & 13,512 & 14,101 & 14,395 & 16,192 & 15,500 & 12,071 \\
\hline Abu Dhabi & 11,979 & 11,857 & 11,798 & 12,312 & 12,901 & 13,195 & 14,992 & 14,300 & 11,471 \\
\hline Cash contributions & 5,600 & 5,610 & 5,619 & 6,171 & 6,779 & 7,119 & 9,857 & 9,743 & 7,398 \\
\hline Federal services $^{2}$ & 6,242 & 6,119 & 6,179 & 6,141 & 6,122 & 6,076 & 5,135 & 4,557 & 4,073 \\
\hline Foreign grants on federal account ${ }^{2}$ & 137 & 128 & 0 & 0 & 0 & 0 & 0 & 0 & 0 \\
\hline Dubai & 1,200 & 1,200 & 1,200 & 1,200 & 1,200 & 1,200 & 1,200 & 1,200 & 600 \\
\hline Total expenditure and grants & 21,579 & 22,147 & 22,533 & 23,289 & 28,551 & 27,800 & 39,781 & 41,338 & 39,592 \\
\hline Current expenditures & 20,743 & 21,357 & 21,693 & 22,082 & 25,605 & 25,461 & 36,572 & 38,563 & 37,178 \\
\hline Wages and salaries ${ }^{3}$ & 7,829 & 7,841 & 7,998 & 8,158 & 8,997 & 9,387 & 13,854 & 15,253 & 13,187 \\
\hline Goods and services (by ministries) & 9,216 & 9,789 & 9,902 & 9,997 & 9,184 & 9,448 & 11,730 & 11,722 & 14,530 \\
\hline Subsidies and transfers & 3,698 & 3,727 & 3,793 & 3,928 & 7,424 & 6,626 & 10,988 & 11,587 & 9,460 \\
\hline Development expenditures & 507 & 614 & 715 & 533 & 466 & 920 & 1,041 & 1,139 & 1,159 \\
\hline Equity positions & 153 & 176 & 125 & 674 & 2,480 & 1,296 & 2,094 & 1,446 & 1,245 \\
\hline Domestic & 153 & 176 & 125 & 674 & 2,480 & 1,296 & 2,094 & 1,446 & 945 \\
\hline Foreign grants & 176 & 128 & 0 & 0 & 0 & 123 & 74 & 191 & 10 \\
\hline Overall balance & 108 & -837 & -516 & 1,649 & 1,836 & 6,740 & 3,021 & 943 & 207 \\
\hline \multicolumn{10}{|l|}{ Memorandum items: } \\
\hline Abu Dhabi federal services ${ }^{4}$ & 17,045 & 19,251 & 23,760 & 22,784 & 25,349 & 31,285 & 45,552 & 55,924 & 72,365 \\
\hline
\end{tabular}

Sources: Ministry of Finance; Abu Dhabi Department of Finance.

${ }^{1}$ Dividends and payouts by Etisalat and other enterprises, including the Central Bank.

${ }^{2}$ Amount budgeted by federal government, but outlays are made by Abu Dhabi.

${ }^{3}$ Beginning 2002, military pension payments of Interior Ministry are classified as wages and salaries.

${ }^{4}$ Mainly military and internal security expenditures not included in the federal accounts. 
Table 9. United Arab Emirates: Federal Subsidies and Transfers, 2002-10

\begin{tabular}{lrrrrrrrrr}
\multicolumn{10}{c}{ (Millions of U.A.E. dirhams) } \\
\hline & 2002 & 2003 & 2004 & 2005 & 2006 & 2007 & 2008 & 2009 & 2010 \\
\hline Subsidies & 1,871 & 2,003 & 2,104 & 2,253 & 4,032 & 1,976 & 2,376 & 2,430 & 2,431 \\
Sheikh Zayed University & 210 & 209 & 179 & 220 & 235 & 228 & 255 & 252 & 252 \\
U.A.E. University & 685 & 747 & 689 & 780 & 794 & 833 & 1,220 & 1,283 & 1,251 \\
Higher College of Technology & 545 & 551 & 443 & 562 & 538 & 632 & 708 & 721 & 781 \\
Emirates Media, Inc. & 180 & 180 & 150 & 180 & 180 & 282 & 192 & 174 & 147 \\
Other & 251 & 316 & 643 & 511 & 2,285 & 0 & 0 & 0 & 0 \\
Transfers & 1,827 & 1,739 & 1,641 & 1,675 & 2,246 & 2,587 & 5,001 & 5,009 & 4,944 \\
Pension Fund & 462 & 600 & 600 & 400 & 400 & 1,646 & 4,101 & 3,709 & 3,649 \\
Marriage Fund & 216 & 216 & 180 & 216 & 216 & 262 & 221 & 221 & 215 \\
Zayed Housing Program & 548 & 500 & 450 & 640 & 640 & 680 & 680 & 1,080 & 1,080 \\
General Pension and & & & & & & & & 0 & 0 \\
$\quad$ Social Security Authority & 601 & 423 & 411 & 419 & 990 & 0 & 0 & 0 \\
Other subsidies and transfers & 0 & 0 & 48 & 0 & 1,146 & 1,042 & 1,761 & 2,246 & 2,483 \\
Total & 3,698 & 3,742 & 3,793 & 3,928 & 7,424 & 5,605 & 9,138 & 9,685 & 9,857 \\
\hline
\end{tabular}

Source: Ministry of Finance.

${ }^{1}$ Transfers to fund pension payments for federal workers retiring in current year, military pensions are included starting 2006. 
Table 10. United Arab Emirates: Abu Dhabi Fiscal Operations, 2002-10

(Millions of U.A.E. dirhams)

\begin{tabular}{|c|c|c|c|c|c|c|c|c|c|}
\hline & 2002 & 2003 & 2004 & 2005 & 2006 & 2007 & 2008 & 2009 & 2010 \\
\hline Total revenue & 44,419 & 60,967 & 77,653 & 126,709 & 183,732 & 204,804 & 300,414 & 143,983 & 188,456 \\
\hline Hydrocarbon revenue & 36,045 & 51,830 & 67,978 & 104,279 & 157,125 & 168,274 & 269,586 & 121,775 & 169,128 \\
\hline Crude oil royalties and taxes & 33,692 & 48,618 & 64,345 & 99,699 & 151,118 & 162,557 & 259,227 & 116,817 & 162,089 \\
\hline Income taxes ${ }^{1}$ & 2,353 & 3,212 & 3,633 & 4,580 & 6,007 & 5,717 & 10,359 & 4,958 & 7,038 \\
\hline Nonhydrocarbon & 8,374 & 9,137 & 9,675 & 22,430 & 26,607 & 36,530 & 30,828 & 22,208 & 19,328 \\
\hline Customs & 294 & 552 & 710 & 635 & 748 & 1,427 & 1,817 & 1,954 & 2,200 \\
\hline Investment income ${ }^{2}$ & 6,587 & 4,054 & 5,965 & 13,549 & 23,107 & 30,797 & 23,167 & 16,596 & 13,106 \\
\hline Other & 1,492 & 1,531 & 3,000 & 2,039 & 2,752 & 4,306 & 5,844 & 3,658 & 4,022 \\
\hline Total expenditure and grants & 66,327 & 69,865 & 74,015 & 79,828 & 92,310 & 121,737 & 187,363 & 261,442 & 245,527 \\
\hline Current expenditures & 43,864 & 45,287 & 50,659 & 52,503 & 65,243 & 81,581 & 105,431 & 138,996 & 165,391 \\
\hline Wages and salaries & 3,374 & 3,454 & 3,169 & 3,169 & 3,236 & 4,813 & 5,861 & 6,006 & 6,717 \\
\hline Goods and services & 10,590 & 12,286 & 12,822 & 12,396 & 13,591 & 22,387 & 32,027 & 48,929 & 63,264 \\
\hline Federal services ${ }^{3}$ & 17,045 & 19,251 & 23,760 & 22,784 & 25,349 & 31,285 & 45,552 & 55,924 & 72,365 \\
\hline Water and electricity & 2,077 & 3,706 & 3,636 & 318 & 0 & 0 & 0 & 0 & 0 \\
\hline Subsidies and transfers & 10,778 & 6,590 & 7,272 & 13,836 & 23,066 & 23,096 & 21,784 & 27,597 & 22,168 \\
\hline Interest payments & 0 & 0 & 0 & 0 & 1 & 0 & 207 & 540 & 877 \\
\hline Development expenditures & 9,203 & 11,816 & 11,898 & 9,792 & 7,321 & 5,041 & 13,211 & 27,635 & 23,643 \\
\hline Water and electricity & 1,748 & 2,766 & 2,147 & 3,002 & 2,428 & 1,902 & 2,300 & 4,154 & 4,154 \\
\hline Other & 7,455 & 9,050 & 9,751 & 6,790 & 4,893 & 3,139 & 10,911 & 23,481 & 23,481 \\
\hline Loans and equity (net) & 497 & -178 & -937 & 4,206 & 6,473 & 19,497 & 49,750 & 77,415 & 43,863 \\
\hline Domestic & 329 & $-1,004$ & 3,025 & 4,813 & 8,798 & 19,218 & 50,460 & 78,324 & 44,243 \\
\hline Building and housing loans & $-1,191$ & $-1,345$ & 1,527 & 1,607 & 2,759 & 10,377 & 38,070 & 26,473 & 6,919 \\
\hline Transfer to Dubai & 0 & 0 & 0 & 0 & 0 & 0 & 0 & 12,129 & 11,000 \\
\hline Equity & 1,520 & 341 & 1,498 & 3,206 & 6,039 & 8,841 & 12,390 & 39,722 & 26,325 \\
\hline Foreign loans & 168 & 826 & $-3,962$ & -607 & $-2,325$ & 279 & -710 & -909 & -380 \\
\hline Grants & 12,763 & 12,940 & 12,395 & 13,327 & 13,273 & 15,618 & 18,971 & 17,396 & 12,629 \\
\hline $\begin{array}{l}\text { Cash contributions to federal } \\
\text { government }\end{array}$ & 5,600 & 5,610 & 5,619 & 6,171 & 6,779 & 7,119 & 9,857 & 9,743 & 7,398 \\
\hline Federal services ${ }^{4}$ & 6,242 & 6,119 & 6,179 & 6,141 & 6,122 & 6,076 & 5,135 & 4,557 & 4,073 \\
\hline Foreign grants on federal account ${ }^{4}$ & 137 & 75 & 0 & 0 & 0 & 294 & 494 & 0 & 0 \\
\hline Foreign grants ${ }^{5}$ & 784 & 1,136 & 597 & 1,015 & 372 & 2,129 & 3,485 & 3,096 & 1,158 \\
\hline Overall balance & $-21,908$ & $-8,898$ & 3,638 & 46,881 & 91,422 & 83,067 & 113,051 & $-117,459$ & $-57,071$ \\
\hline
\end{tabular}

Source: Abu Dhabi Department of Finance.

${ }^{1}$ Income taxes are entirely from ADGAS and GASCO.

${ }^{2}$ Fund staff estimates; not included in finance department accounts.

${ }^{3}$ Mainly defense and security outlays; not included in the federal accounts.

${ }^{4}$ Outlays made by Abu Dhabi, but included in the federal accounts.

${ }^{5}$ Foreign grants on Abu Dhabi account. 
Table 11. United Arab Emirates: Abu Dhabi Development Expenditures, 2002-09 ${ }^{1}$

(Millions of U.A.E. dirhams)

\begin{tabular}{|c|c|c|c|c|c|c|c|c|}
\hline & 2002 & 2003 & 2004 & 2005 & 2006 & 2007 & 2008 & 2009 \\
\hline Agriculture & 681 & 736 & 1,095 & 943 & 331 & 289 & 430 & 506 \\
\hline Electricity and water ${ }^{2}$ & 1,748 & 2,766 & 2,147 & 3,002 & 2,428 & 1,902 & 2,300 & 4,154 \\
\hline Industry \& commerce & 525 & 1,287 & 1,579 & 916 & 288 & 239 & 280 & 333 \\
\hline Transport and communications & 2,570 & 1,993 & 2,340 & 2,357 & 2,715 & 1,310 & 6,708 & 14,371 \\
\hline Housing \& community centers & 690 & 1,933 & 2,066 & 1,189 & 414 & 216 & 1,571 & 1,465 \\
\hline Urban development (reclamation and dredging) & 1,082 & 865 & 320 & 56 & 48 & 126 & 370 & 2,341 \\
\hline Health ${ }^{3}$ & & & 11 & 7 & 55 & 163 & 136 & 563 \\
\hline Sewerage/sanitation & 832 & 869 & 656 & 773 & 541 & 333 & 542 & 1,155 \\
\hline Sports and recreation & 868 & 1,227 & 1,470 & 393 & 395 & 233 & 394 & 1,084 \\
\hline General administration and contingency fund & 207 & 140 & 214 & 156 & 106 & 194 & 241 & 933 \\
\hline Education ${ }^{4}$ & 0 & 0 & 0 & 0 & 0 & 36 & 205 & 655 \\
\hline Religious affairs & 0 & 0 & 0 & 0 & 0 & 0 & 30 & 23 \\
\hline Police and civil defence & 0 & 0 & 0 & 0 & 0 & 0 & 4 & 36 \\
\hline Others (including unallocated reserves) & 0 & 0 & 0 & 0 & 0 & 0 & 0 & 16 \\
\hline Total & 9,203 & 11,816 & 11,909 & 9,792 & 7,321 & 5,041 & 13,211 & 27,635 \\
\hline
\end{tabular}

Source: Abu Dhabi Department of Finance.

${ }^{1}$ Certain expenditures were reclassified as from 1999.

22002 budget likely to be exceeded owing to unresolved issues with ADWEA.

${ }^{3}$ Since 2004, health services in Abu Dhabi, previously managed by the federal government, are managed by Abu Dhabi Health Authority.

${ }^{4}$ Since 2007, education services in Abu Dhabi, previously managed by the federal government, are managed by Abu Dhabi Education Council. 
Table 12. United Arab Emirates: Abu Dhabi Government Transfers and Subsidies, 2002-09 ${ }^{1}$

\begin{tabular}{|c|c|c|c|c|c|c|c|c|}
\hline & 2002 & 2003 & 2004 & 2005 & 2006 & 2007 & 2008 & 2009 \\
\hline Compensation for land & 2 & 120 & 6 & 26 & 45 & 2,032 & 184 & 47 \\
\hline Compensation for crop damage ${ }^{1}$ & 4,277 & 2,450 & 2,411 & 2,092 & 2,098 & 2,246 & 2,468 & 3,195 \\
\hline Grants to sports clubs & 141 & 158 & 143 & 178 & 205 & 288 & 632 & 600 \\
\hline Grants to low cost house owners & 24 & 45 & 21 & 47 & 15 & 7 & 25 & 11 \\
\hline Other subsidies & 493 & 548 & 663 & 905 & 610 & 1,195 & 1,347 & 1,471 \\
\hline Domestic aid $^{2}$ & 5,824 & 2,865 & 2,776 & 3,626 & 16,033 & 10,334 & 9,360 & 12,608 \\
\hline Extra-ordinary expenses & 17 & 404 & 12 & 6,464 & 9 & 51 & 41 & 9 \\
\hline Subsidies to ADWEA 3 & 0 & 0 & 1,261 & 545 & 4,088 & 6,950 & 7,752 & 9,667 \\
\hline Total $^{4}$ & 10,778 & 6,590 & 7,293 & 13,883 & 23,103 & 23,103 & 21,809 & 27,608 \\
\hline
\end{tabular}

Source: Abu Dhabi Department of Finance.

${ }^{1}$ Reflecting the cost of disposition.

2 Transfers to other emirates besides Dubai and Sharjah.

${ }^{3}$ Abu Dhabi Water and Electricity Authority (ADWEA).

${ }^{4}$ For 2005 it includes AED 6.2 billion that the government of Abu Dhabi contributed to its pension fund. 
Table 13. United Arab Emirates: Dubai Government Operations, 2002-10

(Millions of U.A.E. dirhams)

\begin{tabular}{|c|c|c|c|c|c|c|c|c|c|}
\hline & 2002 & 2003 & 2004 & 2005 & 2006 & 2007 & 2008 & 2009 & 2010 \\
\hline Total revenue & 9,103 & 10,047 & 11,978 & 16,900 & 19,831 & 25,605 & 32,618 & 40,554 & 41,931 \\
\hline Tax revenue & 1,413 & 1,997 & 2,415 & 3,317 & 4,630 & 6,838 & 7,604 & 7,132 & 7,319 \\
\hline Customs $^{1}$ & 1,178 & 1,696 & 2,095 & 2,897 & 3,537 & 5,996 & 6,414 & 5,792 & 5,932 \\
\hline Income tax ${ }^{2}$ & 235 & 301 & 320 & 420 & 1,093 & 842 & 1,190 & 1,340 & 1,387 \\
\hline Nontax revenue & 7,690 & 8,050 & 9,563 & 13,583 & 15,201 & 18,767 & 25,014 & 33,422 & 34,612 \\
\hline Oil and gas & 3,735 & 3,766 & 4,213 & 5,902 & 6,259 & 6,770 & 8,495 & 4,703 & 6,466 \\
\hline Enterprise profits ${ }^{3}$ & 1,237 & 1,118 & 1,311 & 1,937 & 2,807 & 1,470 & 1,819 & 770 & 770 \\
\hline Transfers from Abu Dhabi & 0 & 0 & 0 & 0 & 0 & 0 & 0 & 12,129 & 11,000 \\
\hline Other & 2,718 & 3,166 & 4,039 & 5,744 & 6,135 & 10,527 & 14,700 & 15,820 & 16,376 \\
\hline Total expenditure & 9,497 & 10,778 & 10,543 & 12,426 & 17,324 & 26,913 & 40,838 & 95,559 & 61,892 \\
\hline Current & 6,149 & 6,664 & 7,538 & 8,272 & 14,024 & 16,796 & 25,307 & 30,949 & 34,492 \\
\hline Wages and salaries & 2,928 & 3,044 & 3,390 & 3,933 & 5,137 & 5,906 & 8,168 & 10,369 & 12,352 \\
\hline Goods and services ${ }^{4}$ & 1,970 & 1,755 & 2,413 & 2,178 & 1,926 & 3,983 & 5,073 & 6,748 & 6,809 \\
\hline Subsidies and transfers ${ }^{5}$ & 888 & 1,008 & 1,207 & 1,469 & 6,411 & 5,168 & 7,582 & 5,753 & 5,753 \\
\hline Interest payments & 0 & 0 & 0 & 0 & 0 & 412 & 2,841 & 5,340 & 8,596 \\
\hline Other & 363 & 857 & 528 & 692 & 550 & 1,327 & 1,643 & 2,739 & 982 \\
\hline Development & 2,038 & 2,896 & 1,507 & 2,716 & 2,100 & 8,917 & 14,331 & 13,499 & 11,035 \\
\hline Loans and equity (net) & 110 & 18 & 298 & 238 & 0 & 0 & 0 & 49,910 & 15,766 \\
\hline \multicolumn{10}{|l|}{ Grants } \\
\hline Contribution to federal government & 1,200 & 1,200 & 1,200 & 1,200 & 1,200 & 1,200 & 1,200 & 1,200 & 600 \\
\hline Overall balance & -394 & -731 & 1,435 & 4,474 & 2,507 & $-1,308$ & $-8,220$ & $-55,004$ & $-19,961$ \\
\hline
\end{tabular}

Source: Dubai Department of Finance.

${ }^{1}$ All revenues associated with trade and port operations; more than customs duties.

2 Taxes on foreign banks.

${ }^{3}$ Includes DUBAL, DUGAS, Emirates Airlines, Jebel Ali, and other public enterprises.

${ }^{4}$ Includes interest and amortization on some bank loans.

${ }^{5}$ Excludes Water and Electricity, which is settled in an off-budget account. 
Table 14. United Arab Emirates: Monetary Survey, 2002-10

(Millions of U.A.E. dirhams)

\begin{tabular}{|c|c|c|c|c|c|c|c|c|c|}
\hline End of Period Stock & 2002 & 2003 & 2004 & 2005 & 2006 & 2007 & 2008 & 2009 & 2010 \\
\hline Net foreign assets & 128,654 & 131,847 & 145,313 & 166,820 & 155,658 & 160,498 & 33,098 & 46,949 & 78,624 \\
\hline Foreign assets & 166,960 & 167,255 & 194,654 & 253,177 & 334,614 & 482,821 & 316,852 & 298,706 & 350,947 \\
\hline Central bank & 56,229 & 55,518 & 68,546 & 78,149 & 102,676 & 285,924 & 113,466 & 90,549 & 117434 \\
\hline Commercial banks ${ }^{2}$ & 110,731 & 111,737 & 126,108 & 175,028 & 231,938 & 196,897 & 203,386 & 208,157 & 233513 \\
\hline Foreign liabilities & 38,306 & 35,408 & 49,341 & 86,357 & 178,956 & 322,322 & 283,757 & 251,757 & 272,323 \\
\hline Central bank & 284 & 349 & 548 & 1,142 & 1,268 & 1,352 & 1,158 & 671 & 624 \\
\hline Commercial banks ${ }^{2}$ & 38,022 & 35,059 & 48,793 & 85,215 & 177,688 & 320,970 & 282,599 & 251,086 & 271699 \\
\hline Domestic assets & 40,590 & 64,703 & 96,929 & 157,244 & 243,636 & 405,206 & 641,212 & 693,669 & 707,764 \\
\hline Claims on government (net) & $-27,248$ & $-29,517$ & $-31,293$ & $-47,332$ & $-51,882$ & $-61,380$ & $-85,029$ & 9,997 & 28,939 \\
\hline Claims & 14,497 & 20,110 & 30,619 & 43,988 & 55,465 & 69,147 & 139,754 & 218,581 & 227860 \\
\hline Deposits & 41,745 & 49,627 & 61,912 & 91,320 & 107,347 & 130,527 & 224,783 & 208,584 & 198921 \\
\hline Claims on public sector enterprises & 7,122 & 12,990 & 13,884 & 24,797 & 33,002 & 45,385 & 56,064 & 77,259 & 87581 \\
\hline Claims on private nonbanks & 149,352 & 169,469 & 211,407 & 305,546 & 418,151 & 585,998 & 875,130 & 878,006 & 883254 \\
\hline Capital and reserves & $-42,583$ & $-46,063$ & $-54,023$ & $-79,692$ & $-105,649$ & $-132,442$ & $-167,069$ & $-245,531$ & -274538 \\
\hline Other items (net) & $-46,053$ & $-42,176$ & $-43,046$ & $-46,075$ & $-49,986$ & $-32,355$ & $-37,884$ & $-26,062$ & $-17,472$ \\
\hline Central bank & $-31,245$ & $-28,416$ & $-38,951$ & $-47,798$ & $-64,701$ & $-240,957$ & $-107,603$ & $-132,948$ & -157827 \\
\hline Commercial banks & $-14,808$ & $-13,760$ & $-4,095$ & 1,723 & 14,715 & 208,602 & 69,719 & 106,886 & 140355 \\
\hline Domestic liquidity & 169,244 & 196,550 & 242,242 & 324,064 & 399,294 & 565,703 & 674,310 & 740,618 & 786,388 \\
\hline Money & 47,054 & 58,262 & 80,818 & 104,449 & 120,020 & 181,665 & 208,138 & 223,482 & 232,961 \\
\hline Currency outside banks & 11,938 & 13,785 & 15,778 & 17,522 & 21,837 & 25,942 & 36,967 & 37,217 & 38560 \\
\hline Dirham demand deposits & 35,116 & 44,477 & 65,040 & 86,927 & 98,183 & 155,723 & 171,171 & 186,265 & 194401 \\
\hline Quasi-money & 122,190 & 138,288 & 161,424 & 219,615 & 279,274 & 384,038 & 466,172 & 517,136 & 553,427 \\
\hline Foreign currency deposits & 39,605 & 47,980 & 62,496 & 73,804 & 96,307 & 91,007 & 120,210 & 123,001 & 130264 \\
\hline Dirham time and savings deposits & 82,585 & 90,308 & 98,928 & 145,811 & 182,967 & 293,031 & 345,962 & 394,135 & 423163 \\
\hline \multicolumn{10}{|l|}{ Memorandum items: } \\
\hline Dirham-denominated liquidity & 117,701 & 134,785 & 163,968 & 232,738 & 281,150 & 448,754 & 517,133 & 580,400 & 617564 \\
\hline Change in percent & 14.5 & 14.5 & 21.7 & 41.9 & 20.8 & 59.6 & 15.2 & 12.2 & 6.4 \\
\hline
\end{tabular}

Source: Central Bank of the United Arab Emirates.

${ }^{1}$ Compiled in accordance with the residence principle.

2 Including the restricted license bank, Banca Commercial Italiana which ended its operations in May 2003. 
Table 15. United Arab Emirates: Factors Affecting Domestic Liquidity, 2002-10

(Annual changes in millions of U.A.E. dirhams)

\begin{tabular}{|c|c|c|c|c|c|c|c|c|c|}
\hline End of Period & 2002 & 2003 & 2004 & 2005 & 2006 & 2007 & 2008 & 2009 & 2010 \\
\hline Net foreign assets & 29,475 & 3,193 & 13,466 & 21,507 & $-11,162$ & 4,841 & $-127,404$ & 13,854 & 31675 \\
\hline Foreign assets & 16,969 & 295 & 27,399 & 58,523 & 81,437 & 148,207 & $-165,969$ & $-18,146$ & 52241 \\
\hline Central bank & 3,758 & -711 & 13,028 & 9,603 & 24,527 & 183,248 & $-172,458$ & $-22,917$ & 26885 \\
\hline Commercial banks & 13,211 & 1,006 & 14,371 & 48,920 & 56,910 & $-35,041$ & 6,489 & 4,771 & 25356 \\
\hline Foreign liabilities & $-12,506$ & $-2,898$ & 13,933 & 37,016 & 92,599 & 143,366 & $-38,565$ & $-32,000$ & 20566 \\
\hline Central bank & -232 & 65 & 199 & 594 & 126 & 84 & -194 & -487 & -47 \\
\hline Commercial banks ${ }^{1}$ & $-12,274$ & $-2,963$ & 13,734 & 36,422 & 92,473 & 143,282 & $-38,371$ & $-31,513$ & 20613 \\
\hline Domestic assets & $-6,596$ & 24,113 & 32,226 & 60,315 & 86,392 & 161,570 & 236,006 & 52,457 & 14095 \\
\hline Claims on government (net) & $-8,483$ & $-2,269$ & $-1,776$ & $-16,039$ & $-4,550$ & $-9,498$ & $-23,649$ & 95,026 & 18942 \\
\hline Claims & 4,292 & 5,613 & 10,509 & 13,369 & 11,477 & 13,682 & 70,607 & 78,827 & 9279 \\
\hline Deposits & 12,775 & 7,882 & 12,285 & 29,408 & 16,027 & 23,180 & 94,256 & $-16,199$ & -9663 \\
\hline Claims on public sector enterprises & 1,864 & 5,868 & 894 & 10,913 & 8,205 & 12,383 & 10,679 & 21,195 & 10322 \\
\hline Claims on private nonbanks & 15,220 & 20,117 & 41,938 & 94,139 & 112,605 & 167,847 & 289,132 & 2,876 & 5248 \\
\hline Capital and reserves & $-4,206$ & $-3,480$ & $-7,960$ & $-25,669$ & $-25,957$ & $-26,793$ & $-34,627$ & $-78,462$ & -29007 \\
\hline Other items (net) & $-10,991$ & 3,877 & -870 & $-3,029$ & $-3,911$ & 17,631 & $-5,529$ & 11,822 & 8590 \\
\hline Central bank & $-3,251$ & 2,829 & $-10,535$ & $-8,847$ & $-16,903$ & $-176,256$ & 133,354 & $-25,345$ & -24879 \\
\hline Commercial banks & $-7,740$ & 1,048 & 9,665 & 5,818 & 12,992 & 193,887 & $-138,883$ & 37,167 & 33469 \\
\hline Domestic liquidity & 22,875 & 27,306 & 45,692 & 81,822 & 75,230 & 166,409 & 108,607 & 66,308 & 45770 \\
\hline Money & 7,590 & 11,208 & 22,556 & 23,631 & 15,571 & 61,645 & 26,473 & 15,344 & 9479 \\
\hline Currency outside banks & 1,401 & 1,847 & 1,993 & 1,744 & 4,315 & 4,105 & 11,025 & 250 & 1343 \\
\hline Dirham demand deposits & 6,189 & 9,361 & 20,563 & 21,887 & 11,256 & 57,540 & 15,448 & 15,094 & 8136 \\
\hline Quasi-money & 15,285 & 16,098 & 23,136 & 58,191 & 59,659 & 104,764 & 82,134 & 50,964 & 36291 \\
\hline Foreign currency deposits & 6,527 & 8,375 & 14,516 & 11,308 & 22,503 & $-5,300$ & 29,203 & 2,791 & 7263 \\
\hline Dirham time and savings deposits & 8,758 & 7,723 & 8,620 & 46,883 & 37,156 & 110,064 & 52,931 & 48,173 & 29028 \\
\hline
\end{tabular}

Source: Central Bank of the United Arab Emirates.

${ }^{1}$ Including the restricted license bank, Banca Commercial Italiana, which ended its operations in May 2003. 
Table 16. United Arab Emirates: Summary Accounts of the Central Bank, 2002-10

(Millions of U.A.E. dirhams)

\begin{tabular}{|c|c|c|c|c|c|c|c|c|c|}
\hline End of Period & 2002 & 2003 & 2004 & 2005 & 2006 & 2007 & 2008 & 2009 & 2010 \\
\hline Foreign assets & 56,229 & 55,518 & 68,546 & 78,149 & 102,676 & 285,924 & 113,466 & 90,549 & 117,435 \\
\hline Claims on banks & 49,195 & 42,746 & 37,309 & 39,727 & 57,739 & 184,368 & 83,307 & 89,768 & 48169 \\
\hline Loans and investments & 5,509 & 11,348 & 29,564 & 36,909 & 43,299 & 98,857 & 29,576 & 37 & 68418 \\
\hline Other ${ }^{1}$ & 372 & 127 & 516 & 1,021 & 1,295 & 2,467 & 156 & 70 & 115 \\
\hline IMF reserve position & 1,153 & 1,297 & 1,157 & 492 & 343 & 232 & 427 & 674 & 733 \\
\hline Net claims on government & $-1,153$ & $-1,297$ & $-1,157$ & 1,933 & 282 & -232 & 54,573 & 106,051 & 105,992 \\
\hline Claims & 0 & 0 & 0 & 2,425 & 625 & 0 & 55,000 & 106,725 & 106725 \\
\hline Less: IMF reserve position & 1,153 & 1,297 & 1,157 & 492 & 343 & 232 & 427 & 674 & 733 \\
\hline Claims on private nonbanks ${ }^{2}$ & 62 & 75 & 68 & 64 & 59 & 53 & 49 & 56 & 46 \\
\hline Claims on commercial banks & 50 & 0 & 0 & 0 & 0 & 0 & 23,794 & 6,725 & 1421 \\
\hline Unclassified assets & 85 & 156 & 182 & 190 & 216 & 204 & 1,865 & 556 & 4043 \\
\hline Total assets/liabilities & 55,273 & 54,452 & 67,639 & 80,336 & 103,233 & 285,949 & 193,747 & 203,937 & 228,937 \\
\hline Foreign liabilities & 284 & 349 & 548 & 1,142 & 1,268 & 1,352 & 1,158 & 671 & 625 \\
\hline Reserve money & 25,160 & 30,539 & 38,789 & 44,314 & 54,177 & 92,077 & 121,728 & 113,795 & 112,360 \\
\hline Currency outside banks & 11,938 & 13,785 & 15,778 & 17,522 & 21,837 & 25,942 & 36,967 & 37,217 & 38560 \\
\hline Cash held by banks & 1,861 & 2,184 & 2,714 & 3,511 & 4,995 & 5,730 & 8,360 & 8,363 & 9215 \\
\hline Banks' deposits & 11,361 & 14,570 & 20,297 & 23,281 & 27,345 & 60,405 & 76,401 & 68,215 & 64585 \\
\hline Certificates of deposit & 12,489 & 11,762 & 15,977 & 21,033 & 32,322 & 173,577 & 47,183 & 71,453 & 94002 \\
\hline Government deposits ${ }^{3}$ & 10,111 & 10,186 & 10,620 & 12,124 & 13,651 & 15,932 & 20,863 & 15,935 & 15331 \\
\hline Capital and reserves & 1,560 & 1,560 & 1,560 & 1,560 & 1,560 & 1,560 & 1,500 & 1,500 & 1500 \\
\hline Unclassified liabilities ${ }^{4}$ & 5,669 & 56 & 145 & 163 & 255 & 1,449 & 1,318 & 583 & 5119 \\
\hline
\end{tabular}

Source: Central Bank of the United Arab Emirates.

${ }^{1}$ Mainly gold, valued at cost.

${ }^{2}$ Staff loans.

${ }^{3}$ Mainly foreign currency deposits.

${ }^{4}$ Includes undistributed profits in 2002. 
Table 17. United Arab Emirates: Balance Sheets of Commercial Banks, 2002-10 ${ }^{1}$

(Millions of U.A.E. dirhams)

\begin{tabular}{|c|c|c|c|c|c|c|c|c|c|}
\hline End of Period & 2002 & 2003 & 2004 & 2005 & 2006 & 2007 & 2008 & 2009 & 2010 \\
\hline $\begin{array}{c}\text { Reserves } \\
\text { Cash }\end{array}$ & $\begin{array}{r}13,222 \\
1,861\end{array}$ & $\begin{array}{r}16,753 \\
2,184\end{array}$ & $\begin{array}{r}23,011 \\
2,714\end{array}$ & $\begin{array}{r}26,791 \\
3,511\end{array}$ & $\begin{array}{r}32,340 \\
4,995\end{array}$ & $\begin{array}{r}66,135 \\
5,730\end{array}$ & $\begin{array}{r}84,761 \\
8,360\end{array}$ & $\begin{array}{r}76,578 \\
8,363\end{array}$ & $\begin{array}{r}73,800 \\
9215\end{array}$ \\
\hline Deposits with central bank & 11,361 & 14,569 & 20,297 & 23,280 & 27,345 & 60,405 & 76,401 & 68,215 & 64585 \\
\hline Foreign assets & 110,675 & 111,727 & 126,108 & 175,028 & 231,938 & 196,897 & 203,386 & 208,157 & 233513 \\
\hline Claims on government & 15,650 & 21,407 & 31,776 & 42,055 & 55,183 & 69,379 & 85,181 & 112,530 & 121868 \\
\hline Claims on public sector enterprises ${ }^{2}$ & 7,122 & 12,990 & 13,884 & 24,797 & 33,002 & 45,385 & 56,064 & 77,259 & 87581 \\
\hline Claims on private nonbanks & 145,592 & 165,143 & 204,727 & 290,239 & 385,730 & 530,737 & 777,141 & 786,495 & 792030 \\
\hline Claims on nonbank financial institutions & 3,692 & 4,251 & 6,612 & 15,243 & 32,362 & 55,208 & 97,940 & 94,350 & 99708 \\
\hline Central bank certificates of deposit & 12,489 & 11,762 & 15,977 & 21,033 & 32,322 & 173,577 & 47,183 & 71,453 & 94002 \\
\hline Unclassified assets ${ }^{3}$ & 6,938 & 7,390 & 10,451 & 13,317 & 21,677 & 40,080 & 44,293 & 67,475 & 76646 \\
\hline Total assets/liabilities & 315,380 & 351,423 & 432,546 & 608,503 & 824,554 & $1,177,398$ & $1,395,949$ & $1,494,297$ & $1,579,148$ \\
\hline Monetary deposits & 35,116 & 44,477 & 65,040 & 86,927 & 98,183 & 155,723 & 171,171 & 186,265 & 194401 \\
\hline Quasi-monetary deposits & 122,190 & 138,288 & 161,424 & 219,615 & 279,274 & 384,038 & 466,172 & 517,136 & 553,427 \\
\hline Foreign currency & 39,598 & 47,980 & 62,496 & 73,804 & 96,307 & 91,007 & 120,210 & 123,001 & 130264 \\
\hline Local currency & 82,585 & 90,308 & 98,928 & 145,811 & 182,967 & 293,031 & 345,962 & 394,135 & 423163 \\
\hline Foreign liabilities ${ }^{4}$ & 37,972 & 35,059 & 48,793 & 85,215 & 177,688 & 320,970 & 282,599 & 251,086 & 271699 \\
\hline Government deposits & 31,606 & 39,418 & 51,274 & 79,179 & 93,680 & 114,579 & 198,298 & 192,614 & 183162 \\
\hline Government lending funds & 28 & 23 & 18 & 17 & 16 & 16 & 5,622 & 13 & 13 \\
\hline Credit from central bank & 61 & 101 & 25 & 26 & 8 & 2 & 25,260 & 6,776 & 4314 \\
\hline Capital and reserves & 40,975 & 44,455 & 52,463 & 78,132 & 104,089 & 130,882 & 165,569 & 244,031 & 273038 \\
\hline Provision & 32,246 & 31,983 & 29,768 & 30,964 & 33,183 & 20,788 & 25,269 & 41,454 & 53121 \\
\hline Unclassified liabilities & 15,193 & 17,619 & 23,741 & 28,428 & 38,433 & 50,400 & 55,989 & 96,376 & 99094 \\
\hline
\end{tabular}

Source: Central Bank of the United Arab Emirates.

${ }^{1}$ Excluding accounts of the restricted license bank.

${ }^{2}$ Commercial enterprises with significant government ownership, including Dubai Aluminum Company, Dubai Gas Company, Abu Dhabi National

Oil Company, other oil and gas companies owned by Abu Dhabi, and cement companies established by several Emirate governments.

${ }^{3}$ Includes net lending to restricted license bank, Banca Commercial Italiana, which ended its operations in May 2003.

${ }^{4}$ Includes commercial prepayments. 
Table 18. United Arab Emirates: Banking System Structure, 2003-10

\begin{tabular}{|c|c|c|c|c|c|c|c|c|}
\hline & 2003 & 2004 & 2005 & 2006 & 2007 & 2008 & 2009 & 2010 \\
\hline \multicolumn{9}{|l|}{ Number of: } \\
\hline Banks $^{1}$ & 46 & 46 & 46 & 46 & 48 & 52 & 52 & 53 \\
\hline Private $^{1}$ & 31 & 31 & 31 & 31 & 33 & 35 & 36 & 37 \\
\hline Local & 6 & 6 & 6 & 6 & 7 & 7 & 7 & 7 \\
\hline Foreign & 25 & 25 & 25 & 25 & 26 & 28 & 29 & 30 \\
\hline State-owned & 15 & 15 & 15 & 15 & 15 & 17 & 16 & 16 \\
\hline \multicolumn{9}{|l|}{ Foreign-owned subsidiaries } \\
\hline \multicolumn{9}{|l|}{ Banks $^{2}$} \\
\hline Islamic & 2 & 4 & 4 & 4 & 6 & 8 & 8 & 8 \\
\hline Non-Islamic & 44 & 42 & 42 & 42 & 42 & 44 & 44 & 45 \\
\hline Branches of foreign banks & 111 & 111 & 111 & 111 & 111 & 117 & 125 & 133 \\
\hline \multicolumn{9}{|l|}{ Concentration } \\
\hline Banks $^{3}$ & 12 & 13 & 11 & 11 & 11 & 11 & 10 & 10 \\
\hline Assets share & \multicolumn{8}{|c|}{ (Percent) } \\
\hline Banks & 100.0 & 100.0 & 100.0 & 100.0 & 100.0 & 100.0 & 100.0 & 100.0 \\
\hline Private commercial & 35.9 & 36.1 & 35.8 & 36.4 & 38.2 & 36.8 & 35.5 & 34.6 \\
\hline Local & 11.8 & 12.6 & 14.1 & 14.5 & 15.6 & 16.3 & 16.6 & 15.9 \\
\hline Foreign & 24.1 & 23.5 & 21.8 & 21.9 & 22.6 & 20.6 & 18.9 & 18.6 \\
\hline State-owned & 64.1 & 63.9 & 64.2 & 63.6 & 61.8 & 63.2 & 64.5 & 65.4 \\
\hline Banks & 100.0 & 100.0 & 100.0 & 100.0 & 100.0 & 100.0 & 100.0 & 100.0 \\
\hline Islamic & 9.0 & 9.9 & 11.9 & 14.0 & 14.2 & 15.7 & 16.0 & 16.8 \\
\hline Non-Islamic & 91.0 & 90.1 & 88.1 & 86.0 & 85.8 & 84.3 & 84.0 & 83.2 \\
\hline Deposits share & \multicolumn{8}{|c|}{ (Percent) } \\
\hline Banks & 100.0 & 100.0 & 100.0 & 100.0 & 100.0 & 100.0 & 100.0 & 100.0 \\
\hline Private commercial & 39.7 & 38.8 & 38.5 & 40.1 & 39.9 & 37.7 & 37.2 & 35.0 \\
\hline Local & 13.6 & 13.8 & 14.9 & 15.6 & 16.7 & 16.6 & 17.2 & 16.2 \\
\hline Foreign & 26.1 & 25.0 & 23.7 & 24.5 & 23.2 & 21.1 & 20.0 & 18.7 \\
\hline State-owned & 60.3 & 61.2 & 61.5 & 59.9 & 60.1 & 62.3 & 62.8 & 65.0 \\
\hline Banks & 100.0 & 100.0 & 100.0 & 100.0 & 100.0 & 100.0 & 100.0 & 100.0 \\
\hline Islamic & 11.2 & 13.3 & 13.8 & 16.0 & 17.1 & 18.1 & 18.7 & 18.8 \\
\hline Non-Islamic & 88.8 & 86.7 & 86.2 & 84.0 & 82.9 & 81.9 & 81.3 & 81.2 \\
\hline
\end{tabular}

Source: Central Bank of the United Arab Emirates.

${ }^{1}$ Dubai Bank PJSC was established in 2002.

2 In 2003, Grindlays merged with Standard Chartered Bank.

${ }^{3}$ Number of institutions with 75 percent of total assets. 
Table 19. United Arab Emirates: Sectoral Loan Concentration, 2003-10 ${ }^{1}$ (Percent of total credit)

\begin{tabular}{|c|c|c|c|c|c|c|c|c|c|}
\hline & 2003 & 2004 & 2005 & 2006 & 2007 & 2008 & 2008 & 2009 & 2010 \\
\hline Agriculture & 0.4 & 0.3 & 0.3 & 0.3 & 0.3 & 0.3 & 0.3 & 0.1 & 0.1 \\
\hline Mining and quarrying & 1.1 & 1.2 & 1.1 & 1.2 & 1.2 & 1.1 & 1.3 & 0.7 & 0.7 \\
\hline Manufacturing & 5.6 & 5.5 & 5.0 & 5.1 & 5.4 & 5.1 & 4.9 & 4.6 & 4.7 \\
\hline Electricity, gas, and water & 5.6 & 3.7 & 3.0 & 2.3 & 1.9 & 2 & 2.2 & 2.6 & 2.5 \\
\hline Construction (excluding mortgages) & 8.3 & 8.5 & 6.9 & 4.8 & 3.4 & 3.9 & 6.8 & 6.6 & 6.1 \\
\hline Trade & 29.0 & 28.1 & 24.1 & 19.6 & 16.4 & 15.6 & 13.4 & 10.5 & 10.0 \\
\hline Transportation, storage, and communication & 3.2 & 2.8 & 3.0 & 4.1 & 3.4 & 2.5 & 2.7 & 2.9 & 2.7 \\
\hline Financial institutions (excluding banks) ${ }^{2}$ & 1.2 & 1.4 & 2.1 & 3.9 & 5.7 & 6.3 & 7.9 & 9.0 & 8.5 \\
\hline Government & 10.0 & 11.8 & 11.1 & 10.1 & 9 & 8.6 & 7.8 & 9.6 & 9.8 \\
\hline Services & 6.4 & 7.3 & 9.0 & 11.8 & 14.4 & 14.6 & 15.9 & 14.2 & 14.1 \\
\hline Real estate mortgage loans & 5.3 & 4.4 & 5.0 & 6.6 & 7.1 & 6.6 & 6.1 & 6.5 & 6.6 \\
\hline Personal loans & & & & & & 0 & & & 0.0 \\
\hline Business & 12.2 & 14.8 & 19.9 & 18.6 & 17 & 18.2 & 17.3 & 17.9 & 18.8 \\
\hline Consumption & 10.9 & 9.3 & 7.7 & 6.6 & 6.7 & 6.7 & 7.3 & 6.9 & 6.8 \\
\hline Others & 0.8 & 1.0 & 1.8 & 5.0 & 8.1 & 8.5 & 6.1 & 7.9 & 8.6 \\
\hline Total & 100.0 & 100.0 & 100.0 & 100.0 & 100.0 & 100.0 & 100.0 & 100.0 & 100.0 \\
\hline
\end{tabular}

Source: Central Bank of the United Arab Emirates.

${ }^{1}$ Excludes overseas branches.

${ }^{2}$ Includes Abu Dhabi Investment Council (ADIC) and Abu Dhabi Investment Authority (ADIA). 
Table 20. United Arab Emirates: Financial Sector Indicators, 2003-10

(Percent, unless otherwise indicated)

\begin{tabular}{|c|c|c|c|c|c|c|c|c|}
\hline & 2003 & 2004 & 2005 & 2006 & 2007 & 2008 & 2009 & 2010 \\
\hline \multicolumn{9}{|l|}{ Core indicators } \\
\hline \multicolumn{9}{|l|}{ Deposit-taking institutions } \\
\hline Total regulatory capital to risk-weighted assets ${ }^{1}$ & 18.6 & 16.9 & 17.4 & 16.6 & 14.0 & 13.3 & 19.2 & 20.8 \\
\hline Regulatory Tier I capital to risk-weighted assets & 18.2 & 16.3 & 16.9 & 15.0 & 12.4 & 12.3 & 15.4 & 16.1 \\
\hline Nonperforming loans net of provisions to capital & 7.7 & 3.5 & 1.8 & 0.6 & 0.0 & 0.0 & 3.1 & 4.2 \\
\hline Nonperforming loans to total gross loans & 14.3 & 12.5 & 8.3 & 6.3 & 2.9 & 2.5 & 4.8 & 6.3 \\
\hline Return on assets & 2.3 & 2.1 & 2.7 & 2.3 & 2.0 & 1.8 & 1.3 & 1.4 \\
\hline Return on equity & 16.4 & 18.6 & 22.5 & 18.0 & 19.3 & 15.6 & 7.9 & 8.4 \\
\hline Interest margin to gross income & 59.5 & 64.6 & 49.3 & 29.3 & 32.4 & 40.2 & 43.8 & 47.3 \\
\hline Noninterest expenses to gross income & 43.6 & 40.3 & 26.9 & 20.9 & 21.4 & 26.3 & 25.0 & 26.8 \\
\hline Liquid assets to total assets & 22.7 & 23.2 & 26.9 & 16.4 & 13.2 & 6.3 & 13.2 & 17.2 \\
\hline \multicolumn{9}{|l|}{ Encouraged indicators } \\
\hline \multicolumn{9}{|l|}{ Deposit-taking institutions } \\
\hline Capital to assets & 11.4 & 11.1 & 11.9 & 12.6 & 10.5 & 11.8 & 16.0 & 16.7 \\
\hline Personnel expenses to noninterest expenses & 29.5 & 38.6 & 41.8 & 54.6 & 55.1 & 54.4 & 53.3 & 54.4 \\
\hline Customer deposits to total (non-interbank) loans & 125.0 & 113.6 & 112.4 & 96.5 & 99.7 & 90.6 & 92.6 & 96.5 \\
\hline \multicolumn{9}{|l|}{ Households } \\
\hline Household debt to GDP & 6.6 & 6.1 & 6.9 & 5.2 & 6.0 & 7.4 & 7.6 & - \\
\hline Real estate loans to total loans & 5.4 & 4.7 & 5.0 & 5.9 & 8.3 & 13.1 & 14.4 & 16.4 \\
\hline \multicolumn{9}{|l|}{ Other indicators } \\
\hline Loan loss reserves/nonperforming loans & 88.5 & 94.6 & 95.7 & 98.2 & 100.0 & 100.8 & 85.0 & 83.3 \\
\hline Deposits as percent of $\mathrm{M} 2$ & 118.4 & 119.9 & 126.4 & 130.0 & 127.3 & 136.9 & 132.7 & 133.5 \\
\hline Commercial banks loans to private sector as percent & & & & & & & & \\
\hline of total deposits & 70.9 & 70.5 & 70.8 & 60.4 & 61.5 & 71.3 & 66.7 & 63.0 \\
\hline Number of commercial banks (end-of-period) & 46 & 46 & 46 & 46 & 49 & 52 & 52 & 53 \\
\hline Number of banks with C.A.R. above 10 percent & 46 & 46 & 46 & 46 & 49 & 52 & 52 & 53 \\
\hline Foreign currency deposits as percent of M2 & 40.3 & 39.6 & 44.5 & 47.0 & 34.3 & 37.4 & 33.7 & 32.2 \\
\hline Foreign currency denominated lending/total lending & 23.9 & 20.7 & 19.7 & 22.8 & 20.8 & & 14.8 & 14.2 \\
\hline Earning per employee (in millions of AED) & 0.4 & 0.5 & 0.7 & 0.7 & 0.8 & 0.7 & 0.5 & 0.6 \\
\hline
\end{tabular}

Source: Central Bank of the United Arab Emirates.

${ }^{1}$ Tier 2 plus tier 2 capital items (net of deductions). 
Table 21. United Arab Emirates: Banking System Income Statement and Profitability, 2003-10 ${ }^{1}$

\begin{tabular}{|c|c|c|c|c|c|c|c|c|}
\hline & 2003 & 2004 & 2005 & 2006 & 2007 & 2008 & 2009 & 2010 \\
\hline & \multicolumn{8}{|c|}{ (Percent of total assets ) } \\
\hline Total income & 5.3 & 5.2 & 6.4 & 7.1 & 6.7 & 6.2 & 6.3 & 5.8 \\
\hline Interest income & 3.1 & 3.4 & 4.2 & 5.2 & 5.2 & 4.8 & 4.9 & 4.5 \\
\hline Fees & 0.7 & 0.7 & 0.9 & 0.8 & 0.6 & 0.7 & 0.8 & 0.7 \\
\hline Foreign exchange income & 0.2 & 0.3 & 0.3 & 0.4 & 0.3 & 0.3 & 0.2 & 0.2 \\
\hline Other income & 1.2 & 0.9 & 1.0 & 0.7 & 0.6 & 0.3 & 0.4 & 0.3 \\
\hline \multicolumn{9}{|l|}{ Securities } \\
\hline \multicolumn{9}{|l|}{ Real estate } \\
\hline Total expenses & 3.3 & 3.2 & 3.7 & 4.8 & 4.7 & 4.3 & 5.0 & 4.4 \\
\hline Interest expense & 1.0 & 1.1 & 2.0 & 3.1 & 3.0 & 2.3 & 2.1 & 1.8 \\
\hline Provisions & 0.5 & 0.5 & 0.4 & 0.3 & 0.4 & 0.6 & 1.4 & 1.1 \\
\hline Wages & 0.7 & 0.8 & 0.7 & 0.7 & 0.7 & 0.8 & 0.8 & 0.8 \\
\hline Other expenses & 1.1 & 0.8 & 0.6 & 0.6 & 0.6 & 0.7 & 0.7 & 0.7 \\
\hline \multicolumn{9}{|l|}{ Gross income } \\
\hline Net profit/loss & 1.9 & 2.1 & 2.7 & 2.3 & 2.0 & 1.8 & 1.3 & 1.4 \\
\hline
\end{tabular}

Source: Central Bank of the United Arab Emirates.

${ }^{1}$ Includes overseas branches. 
Table 22. United Arab Emirates: Balance of Payments, 2002-10

\begin{tabular}{|c|c|c|c|c|c|c|c|c|c|}
\hline & 2002 & 2003 & 2004 & 2005 & 2006 & 2007 & 2008 & 2009 & 2010 \\
\hline & \multicolumn{9}{|c|}{ (Billions of U.S. dollars) } \\
\hline $\begin{array}{l}\text { Current account balance } \\
\text { (In percent of GDP) }\end{array}$ & $\begin{array}{l}2.7 \\
2.5\end{array}$ & $\begin{array}{l}6.5 \\
5.2\end{array}$ & $\begin{array}{l}8.3 \\
5.6\end{array}$ & $\begin{array}{l}20.9 \\
11.6\end{array}$ & $\begin{array}{l}33.9 \\
15.3\end{array}$ & $\begin{array}{r}15.4 \\
6.0\end{array}$ & $\begin{array}{r}23.3 \\
7.4\end{array}$ & $\begin{array}{l}8.2 \\
3.0\end{array}$ & $\begin{array}{r}23.3 \\
7.7\end{array}$ \\
\hline Trade balance & $\begin{array}{l}14.2 \\
518\end{array}$ & 20.9 & $\begin{array}{l}27.6 \\
90.9\end{array}$ & $\begin{array}{r}42.8 \\
1173\end{array}$ & $\begin{array}{r}57.5 \\
1456\end{array}$ & $\begin{array}{r}46.5 \\
178.6\end{array}$ & $\begin{array}{r}63.8 \\
2401\end{array}$ & $\begin{array}{r}42.5 \\
192 ?\end{array}$ & $\begin{array}{r}63.5 \\
2219\end{array}$ \\
\hline Oil and products & 19.6 & 25.3 & 34.0 & 49.3 & 62.9 & 65.7 & 91.4 & 59.6 & 66.8 \\
\hline Gas & 3.3 & 3.9 & 4.8 & 5.8 & 7.2 & 8.1 & 11.5 & 8.6 & 10.7 \\
\hline Nonhydrocarbon & 10.6 & 14.1 & 18.3 & 22.4 & 28.5 & 34.2 & 43.0 & 44.0 & 53.5 \\
\hline Re-exports, of which: ${ }^{1}$ & 18.3 & 23.4 & 33.9 & 39.8 & 47.0 & 70.6 & 94.2 & 80.1 & 90.8 \\
\hline Imports & -37.5 & -45.8 & -63.3 & -74.5 & -88.1 & -132.1 & -176.3 & -149.7 & -158.3 \\
\hline Income, net & 0.6 & -0.7 & -1.6 & -0.6 & 2.6 & 4.2 & 3.9 & 3.3 & 0.1 \\
\hline Services, net & -7.7 & -9.1 & -12.1 & -14.6 & -18.0 & -26.0 & -33.8 & -27.4 & -28.1 \\
\hline Credits & 2.6 & 2.8 & 3.0 & 4.8 & 6.8 & 8.1 & 9.6 & 10.2 & 11.8 \\
\hline Debits & -10.3 & -11.8 & -15.1 & -19.4 & -24.9 & -34.0 & -43.4 & -37.6 & -39.9 \\
\hline Transfers, net & -4.4 & -4.7 & -5.7 & -6.7 & -8.2 & -9.3 & -10.6 & -10.2 & -11.4 \\
\hline Private & -4.1 & -4.4 & -5.3 & -6.2 & -7.6 & -8.7 & -10.0 & -9.5 & -10.6 \\
\hline Official & -0.3 & -0.3 & -0.4 & -0.5 & -0.6 & -0.6 & -0.6 & -0.7 & -0.7 \\
\hline Financial account b & -6.1 & -1.5 & 4.2 & 0.1 & 0.7 & 27.9 & -19.9 & 9.3 & 2.0 \\
\hline Private capital & -1.9 & 3.9 & 12.5 & 15.0 & 22.5 & 58.4 & 9.6 & -4.4 & 6.2 \\
\hline Direct investment, net & 3.1 & 3.3 & 7.8 & 7.2 & 1.9 & -0.4 & -2.1 & 1.3 & 2.0 \\
\hline Portfolio securities, net & 0.2 & 0.0 & 2.0 & 6.1 & 1.2 & 1.4 & 2.2 & 2.5 & 1.0 \\
\hline Commercial banks & -6.9 & -1.1 & -0.2 & -3.4 & 9.7 & 48.6 & -12.2 & -9.9 & -1.3 \\
\hline Private nonbanks and other & 1.7 & 1.8 & 2.9 & 5.1 & 9.7 & 8.8 & 21.7 & 1.8 & 4.6 \\
\hline Official capital $^{2}$ & -4.2 & -5.5 & -8.3 & -14.9 & -21.8 & -30.5 & -29.5 & 13.6 & -4.3 \\
\hline Errors and omissions & 4.5 & -5.1 & -9.0 & -18.5 & -27.9 & 6.5 & -50.2 & -23.5 & -17.9 \\
\hline (As pe & 4.1 & -4.1 & -6.1 & -10.3 & -12.6 & 2.5 & -16.0 & -8.7 & -5.9 \\
\hline Overall balance & 1.1 & -0.2 & 3.5 & 2.5 & 6.6 & 49.9 & -46.8 & -6.0 & 7.3 \\
\hline Change in Central Bank net foreign assets ${ }^{3}$ & -1.1 & 0.2 & -3.5 & -2.5 & -6.6 & -49.9 & 46.9 & 6.1 & -7.3 \\
\hline \multicolumn{10}{|l|}{ Memorandum items: } \\
\hline Overall balance (as & 1.0 & -0.2 & 2.4 & 1.4 & 3.0 & 19.3 & -14.9 & -2.2 & 2.4 \\
\hline Gross reserves of Central Bank & 15.3 & 15.1 & 18.7 & 21.3 & 28.0 & 77.9 & 30.9 & 24.7 & 32.0 \\
\hline (In months of imports) ${ }^{4}$ & 3.2 & 2.3 & 2.4 & 2.3 & 2.0 & 4.3 & 2.0 & 1.5 & 1.7 \\
\hline
\end{tabular}

Sources: Central Bank of the United Arab Emirates; and Fund staff estimates.

${ }^{1}$ Not formally compiled; estimated at 40 to 70 percent of emirates imports.

${ }^{2}$ Includes changes in government external assets.

${ }^{3}$ Minus equals increase.

${ }^{4}$ Imports of goods and services in the next 12 months. 
Table 23. United Arab Emirates: Merchandise Imports by Harmonized

System Sections, 2002-09 ${ }^{1}$

(Millions of U.A.E. dirhams)

\begin{tabular}{|c|c|c|c|c|c|c|c|c|}
\hline & 2002 & 2003 & 2004 & 2005 & 2006 & 2007 & 2008 & 2009 \\
\hline Live animals, animal products & 3,049 & 3,254 & 3,719 & 3,689 & 5,033 & 6,224 & 8,775 & 8,319 \\
\hline Vegetable products & 5,523 & 5,768 & 6,663 & 7,908 & 9,045 & 12,036 & 18,464 & 18,684 \\
\hline Fats, oil and waxes & 362 & 419 & 700 & 915 & 1,150 & 1,437 & 2,891 & 1,624 \\
\hline Foodstuffs, beverages, spirits, and tobacco & 3,481 & 4,942 & 6,230 & 8,044 & 8,187 & 8,764 & 9,406 & 8,868 \\
\hline Mineral products & 1,324 & 2,136 & 6,775 & 3,902 & 6,199 & 7,860 & 11,473 & 9,383 \\
\hline Chemicals and related materials & 7,180 & 8,928 & 11,333 & 13,566 & 15,930 & 21,717 & 26,630 & 24,063 \\
\hline Plastics and rubber & 4,693 & 5,574 & 7,493 & 9,126 & 10,715 & 14,303 & 17,842 & 13,720 \\
\hline Raw hides, leather, and articles thereof & 1,431 & 585 & 893 & 1,153 & 1,383 & 1,673 & 1,922 & 1,802 \\
\hline Wood, cork, and articles thereof & 1,124 & 1,332 & 1,931 & 2,493 & 2,949 & 4,244 & 4,798 & 3,066 \\
\hline Wood pulp, paper, and paperboard & 1,574 & 1,880 & 2,230 & 2,706 & 3,220 & 3,883 & 4,968 & 4,048 \\
\hline Textiles and textile articles & 10,573 & 11,262 & 13,298 & 13,515 & 14,823 & 17,491 & 20,068 & 17,495 \\
\hline Footwear and other accessories & 1,049 & 1,153 & 1,478 & 1,694 & 1,913 & 2,313 & 2,724 & 2,594 \\
\hline Stone, plaster, cement, ceramic, and glassware & 2,522 & 3,180 & 3,994 & 4,342 & 5,813 & 6,824 & 9,079 & 7,841 \\
\hline Pearls, precious stones, and precious metals ${ }^{2}$ & 17,358 & 21,181 & 38,059 & 50,711 & 52,503 & 76,894 & 121,689 & 101,498 \\
\hline Base metals and related products & 9,888 & 13,305 & 18,341 & 23,504 & 33,348 & 45,507 & 82,724 & 41,206 \\
\hline Machinery and electrical equipment & 29,805 & 34,073 & 45,904 & 59,191 & 68,561 & 89,129 & 120,436 & 108,134 \\
\hline Vehicles and other transport equipment & 14,867 & 21,538 & 24,598 & 30,561 & 36,983 & 51,307 & 80,777 & 57,205 \\
\hline Optical and medical equipment & 3,283 & 3,524 & 4,520 & 5,002 & 5,935 & 7,466 & 8,745 & 8,376 \\
\hline Arms and ammunition & 17 & 38 & 285 & 394 & 1,152 & 1,031 & 1,234 & 252 \\
\hline Miscellaneous manufactured goods & 3,355 & 3,582 & 4,414 & 5,130 & 6,148 & 8,124 & 10,635 & 8,702 \\
\hline Works of art and antiques & 125 & 123 & 37 & 46 & 61 & 129 & 441 & 513 \\
\hline Total imports, c.i.f. & 122,582 & 147,776 & 202,896 & 247,590 & 291,049 & 388,357 & 565,720 & 447,394 \\
\hline
\end{tabular}

Source: Central Bank of the United Arab Emirates.

${ }^{1}$ Imports of the Emirates of Abu Dhabi, Dubai, and Sharjah.

${ }^{2}$ As from 2002 imports of nonmonetary gold included by Dubai authorities. 
Table 24. United Arab Emirates: Merchandise Exports by Harmonized System Sections, 2002-09 ${ }^{1}$

(Millions of U.A.E. dirhams)

\begin{tabular}{|c|c|c|c|c|c|c|c|c|c|c|}
\hline & 2000 & 2001 & 2002 & 2003 & 2004 & 2005 & 2006 & 2007 & 2008 & 2009 \\
\hline Live animals, animal products & 102 & 58 & 129 & 140 & 425 & 274 & 376 & 253 & 290 & 773 \\
\hline Vegetable products & 112 & 237 & 214 & 226 & 2,330 & 512 & 299 & 241 & 345 & 301 \\
\hline Fats, oil and waxes & 137 & 106 & 158 & 205 & 475 & 372 & 476 & 465 & 746 & 303 \\
\hline Foodstuffs, beverages, spirits, and tobacco & 343 & 320 & 469 & 1,081 & 1,610 & 2,411 & 2,635 & 3,024 & 3,596 & 4,265 \\
\hline Mineral products & 349 & 536 & 1,291 & 1,258 & 807 & 1,279 & 5,047 & 4,350 & 4,994 & 3,713 \\
\hline Chemicals and related materials & 293 & 359 & 423 & 441 & 501 & 931 & 1,007 & 1,142 & 1,426 & 1,693 \\
\hline Plastics and rubber & 160 & 215 & 691 & 1,094 & 492 & 2,760 & 2,861 & 3,763 & 5,535 & 5,211 \\
\hline Raw hides, leather, and articles thereof & 7 & 11 & 25 & 18 & 18 & 22 & 30 & 42 & 24 & 20 \\
\hline Wood, cork, and articles thereof & 3 & 8 & 4 & 4 & 9 & 53 & 44 & 57 & 25 & 30 \\
\hline Wood pulp, paper, and paperboard & 113 & 178 & 220 & 260 & 205 & 604 & 582 & 885 & 1,139 & 1,424 \\
\hline Textiles and textile articles & 1,005 & 908 & 822 & 719 & 689 & 831 & 993 & 1,184 & 1,366 & 1,005 \\
\hline Footwear and other accessories & 3 & 13 & 6 & 4 & 9 & 23 & 35 & 34 & 86 & 106 \\
\hline Stone, plaster, cement, ceramic, and glassware & 162 & 394 & 490 & 923 & 1,523 & 969 & 1,230 & 2,057 & 9,652 & 1,904 \\
\hline Pearls, precious stones, and precious metals & 276 & 62 & 120 & 32 & 1,665 & 578 & 5,092 & 11,389 & 23,943 & 32,896 \\
\hline Base metals and related products & 3,052 & 3,476 & 3,288 & 3,221 & 3,092 & 3,616 & 4,533 & 5,230 & 5,215 & 8,019 \\
\hline Machinery and electrical equipment & 246 & 272 & 155 & 196 & 210 & 615 & 1,059 & 924 & 1,008 & 1,387 \\
\hline Vehicles and other transport equipment & 135 & 247 & 41 & 582 & 416 & 326 & 1,889 & 635 & 406 & 1,718 \\
\hline Optical and medical equipment & 2 & 10 & 8 & 18 & 0 & 14 & 20 & 54 & 84 & 80 \\
\hline Arms and ammunition & $\ldots$ & $\ldots$ & 0 & 1 & $\ldots$ & 3 & 2 & 27 & 18 & 8 \\
\hline Miscellaneous manufactured goods & 41 & 119 & 91 & 85 & 130 & 231 & 386 & 409 & 458 & 414 \\
\hline Works of art and antiques & 20 & 5 & 4 & 81 & 9 & 39 & 636 & 98 & 3 & 9 \\
\hline Total exports ${ }^{2}$ & 6,561 & 7,536 & 8,649 & 10,589 & 14,615 & 16,463 & 29,232 & 36,262 & 60,359 & 65,279 \\
\hline
\end{tabular}

Source: Central Bank of the United Arab Emirates.

${ }^{1}$ Exports of the Emirates of Abu Dhabi, Dubai, and Sharjah.

${ }^{2}$ Data exclude free zone exports and "re-exports." 